OECDpublishing

\title{
SERVICES TRADE IN THE UNITED KINGDOM AND THE GLOBAL ECONOMY
}

\section{OECD TRADE POLICY PAPER}

\section{November $2021 \quad \mathbf{n}^{\circ} \mathbf{2 5 7}$}




\title{
Services Trade in the United Kingdom and the Global Economy
}

\begin{abstract}
Annabelle Mourougane, Sebastian Benz, Frédéric Gonzales
Services play a more important role in trade and employment in the United Kingdom than in most other OECD countries. The UK services sector is supported by an open and transparent trade regime, policies that support competition and innovation, and regulatory transparency that facilitates the creation of new services businesses and start-ups. That said, certain barriers to services trade remain. This report sheds light on the role of services trade in the UK economy, describing recent trends and highlighting future challenges, and explores policy options to support a sustainable recovery from the COVID-19 crisis.
\end{abstract}

Keywords: Services Trade Restrictiveness Index, COVID-19

JEL codes: F13, F15, F14, F68, L80, O52

\section{Acknowledgements}

This report was supported by a voluntary contribution from the Department of International Trade (DIT) of the United Kingdom. The authors would like to thank John Drummond, Janos Ferencz, Alexander Jaax, and Marion Jansen for helpful discussions and comments. The project also benefitted from exchanges with and comments from colleagues in DIT, in particular Gabriel Montagu-Pollock, Nikos Tsotros, Alice Lyon, and Mark Namazi. Finally, the authors would like to thank Laëtitia Christophe and Michèle Patterson for preparing this report for publication. 


\section{Table of contents}

Executive Summary 4

1. The importance of services in the UK economy 6

The United Kingdom is a service-based economy 6

Digital trade is increasingly important

Services and international trade in value added terms $\quad 15$

Although beneficial, international investment is slowing $\quad 17$

References 23

2. UK services performance and competitiveness 24

The United Kingdom demonstrates dynamic growth in services trade 24

Revealed comparative advantage and diversification of export markets and services types $\quad 27$

The role of SMEs for services trade 30

Large foreign-owned firms account for a large share of UK services trade 32

UK services depend heavily on final demand from the European Union 33

Growth of services productivity has slowed 34

There is evidence that services trade is beneficial to job creation and wages, notably in the United Kingdom 37

Vulnerability of services workers amid COVID-19 38

References $\quad 41$

3. Uncover the United Kingdom's domestic policy and regulatory setting for services 42

The regulatory environment is one of the most favourable in the OECD 42

The general economic environment is favourable $\quad 45$

$\begin{array}{ll}\text { Sector-specific restrictions remain limited } & 47\end{array}$

Restrictions to trade in digitally-enabled services are low $\quad 59$

Identifying divergence in regulations between the United Kingdom and trade partners $\quad 62$

There are very few differences within the UK internal market 63

$\begin{array}{ll}\text { References } & 63\end{array}$

4. Scope for reforms and policy recommendations 64

$\begin{array}{ll}\text { Potential gains from unilateral liberalisation of services sectors } & 64\end{array}$

Recommendations to strengthen the recovery and ensure its sustainability 68

References $\quad 69$

\section{Figures}

Figure 1. Share of services in the UK economy, percentage, 2019

Figure 2. Share of services in value added and employment in the United Kingdom, percentage, 1997-2019 7

Figure 3. Share of value-added and employment by sector, 2019

Figure 4. $\quad$ Business investment by sector, United Kingdom, 2019

Figure 5. Share of goods and services in UK trade, 2019

Figure 6. Services trade over time in the United Kingdom 10

Figure 7. Composition of UK services exports and imports, percentage, 2019

Figure 8. Exports of potentially digitally-delivered services, percentage of total services exports, $2019 \quad 15$

Figure 9. Services value added share of gross exports, $2016 \quad 15$ 
Figure 10. UK services content of gross exports of manufacturing industries, 2016

Figure 11. Share of services value added in manufacturing exports, selected countries, 2005-2015 17

Figure 12. Productivity in UK services firms with and without FDI links, 2018, GBP thousand 17

Figure 13. Mode 3 services exports relative to domestic sales in the United Kingdom and in the OECD, 201618

Figure 14. Services trade collapse at the start of the COVID-19 crisis

Figure 15. Impact of the COVID-19 crisis on trade flows in the United Kingdom, difference to baseline, percentage

Figure 16. Trade costs arising from the passenger travel bans, percentage of export values 22

Figure 17. Services export growth in selected OECD countries, 2012=100, 2012-2019 24

Figure 18. Services imports growth in selected OECD countries, 2012=100, 2012-2019 25

Figure 19. Determinants of UK services export growth, 2013-2019 26

Figure 20. Index of UK revealed comparative advantage, $2019 \quad 27$

Figure 21. Index of revealed comparative advantage in selected OECD economies, 2019

Figure 22. Drivers of services export growth, per cent contribution, UK vs OECD average, 2010 to 201928

Figure 23. UK services export growth by sector and initial export value, 2015-2019 29

Figure 24. UK services export growth by market and initial export value, 2015-2019 30

Figure 25. Contribution of SMEs to UK services trade in $2018 \quad 31$

Figure 26. Contribution of SMEs to UK services trade by sector, $2018 \quad 31$

Figure 27. Contribution to total trade in services by firm ownership and size, 2018

Figure 28. Contribution of foreign-owned firms to UK services trade by sector, 2018

Figure 29. UK value added in USD 1000 of final demand in major economies 33

Figure 30. Decomposition of UK total factor productivity growth in services, 1996-2016 34

Figure 31. Total factor productivity growth in services pre- and post-global financial crisis, selected economies

Figure 32. Decomposition of UK TFP growth in services, by sector, average 2011-2016 36

Figure 33. UK TFP growth by sector, 2011-2019 36

Figure 34. Change in UK hours worked by sector, Q1 2020 - Q3 2020

Figure 35. UK working from home patterns, by sector and gender, 2018

Figure 36. Share of workers with partial teleworking, $2018 \quad 40$

Figure 37. UK Services Restrictiveness Index by sector, 2020

Figure 38. UK Services Trade Restrictiveness Index, percentage change over the period 2014-2016,
2016-2019 and 2019-2020

Figure 39. Contributions to the services trade restrictions in the United Kingdom, Services Trade

Restrictiveness Index, 2020

Figure 40. Services Trade Restrictiveness Index in air transport, 2020

Figure 41. Services Trade Restrictiveness Index in road freight transport, 2020

Figure 42. Services Trade Restrictiveness Index in accounting and auditing, 2020

Figure 43. Services Trade Restrictiveness Index in architectural services, 2020

Figure 44. Services Trade Restrictiveness Index in telecommunications, 2020

Figure 45. Services Trade Restrictiveness Index in motion pictures, $2020 \quad 58$

Figure 46. Digital STRI

Figure 47. Estimated reduction in services trade costs due to the liberalising reforms implemented in December 2020, percentage of trade values, medium-term

Figure 48. UK Trade costs reductions from halving the regulation gap compared to the best performer

\section{Tables}

Table 1. UK trade in services by partner country, 2019

Table 2. Top 3 exporting services sectors by UK NUTS1 region, $2018 \quad 14$

Table 3. STRI ranking by sector, $2020 \quad 44$

Table 4. Regulatory convergence with the United Kingdom in 2020, by sector 62

Table 5. Coefficients used for the computation of trade costs 66 


\section{Executive Summary}

This report seeks to cast light on the role of services trade on the UK economy, underscoring the potential for regulatory reforms to raise competitiveness and productivity in services sectors. Growth and prosperity are fostered by an open and transparent trade regime, policies that support competition and innovation and regulatory transparency that facilitates the creation of new businesses and start-ups in services. Historically, the United Kingdom has been relying on international trade and investment to grow. This has contributed to support employment and wage growth. Services exports are much more prevalent than most other OECD countries, while services imports in terms of GDP are average. The UK's share of services trade that can potentially be delivered digitally is now one of the highest amongst OECD countries, reflecting a particularly high share of digital financial services exports. UK services also support global value chains in other sectors. Services are an important input to manufacturing exports, contributing around a third to the exports of the UK manufacturing sector - a similar share as in France and Italy.

Over the years, the United Kingdom has specialised in specific services sectors. London is now a world leader in finance, pension and insurance services and financial services exports also play a major role for most other regions. More generally, the United Kingdom performs strongly in skill-intensive tradable services. But, since the financial crisis, productivity growth has been sub-par historically and compared to peers, hampering long-term growth prospects. More recently, the outbreak of the coronavirus has increased the vulnerability of workers in the services sectors, such as accommodation and food, transport, as well as wholesale and retail trade sectors, which are less prone to teleworking. Teleworking is also less prevalent among vulnerable workers. This may have implications on inequality and inclusiveness in the future.

Well-performing services sectors will be key to support a sustainable recovery from the COVID-19 crisis. The United Kingdom has been one of most affected countries by the outbreak of the coronavirus in the OECD, at a time where the economy was just exiting a long period of subdued growth and high Brexit-related uncertainties. Stringent containment measures have hit some services sectors severely. Given the predominance of services sectors in the UK economy and the large spillovers of services onto others sectors, this is likely to have sizeable effects on the economy as a whole. Looking forward, a sustainable recovery will rely on the pace at which services sectors can adapt to the new environment and rules, at least until the pandemic is fully under control.

Barriers to trade, investment and competition in the UK's services sectors are, in most dimensions, low. This creates a relatively supportive business environment compared to most other countries. Despite these good international performance there is still scope to lower services trade costs. Several regulations related to movement of people, contribute to the stringency of the general regulatory environment. Specifically, barriers to business travel and rules regarding the employment of foreign services providers, which are larger than in many of the UK's trade partners, have raised services trade costs and are detrimental to UK services firms' productivity.

While the United Kingdom's overall regulatory framework fares well internationally, some specific regulations may hamper firms' performance. This is particularly important when those regulations apply to sectors which play a key role in connectivity and digitalisation, such as telecommunications. Restrictions on digital services trade are low in the United Kingdom by international standards, but existing restrictions are likely to have a stronger effect in the post-COVID-19 crisis environment. 
Reforms to enhance market access could bring sizeable gains. Closing half of the gap to best performers in terms of services trade regulations, as measured by the OECD Services Trade Restrictiveness Index, could lead to an average decrease in services trade costs of about $3.5 \%$ of export values in the medium term. This would lead to sizeable trade gains (Nordas and Rouzet, 2017).

\section{Key recommendations}

- Wind down temporary trade restrictions that were imposed to contain the pandemic or trade barriers that pre-exist the crisis. In particular, trade restrictions on digital trade or in key enabling sectors are likely to have even more effect as social distancing rules are put in place.

- Address barriers to services jointly with those of goods, given the complementarity of services and goods trade. In the United Kingdom, services offshoring has favoured productivity of manufacturing exports firms and barriers to services imports can have significant consequences for the sector.

- Protect vulnerable workers and facilitate the transition to digital through training. The COVID-19 crisis is expected to disproportionately affect workers in services sectors where teleworking is less prevalent. Those sectors will need to adapt to a new environment where social distancing rules may prevail for some time. Targeted support would mitigate the economic damages in sectors that were hit hardest by the crisis.

- Liberalise regulations related to labour-market access of foreign services providers in the accounting and the architecture services. 


\section{The importance of services in the UK economy}

The United Kingdom has relied extensively on open access to services markets and a transparent trade regime to foster living standards. Trade in services has grown at a fast pace since the mid-1990s up until the COVID-19 crisis. The shares of services in export production and employment are amongst the highest in the OECD countries, but services sectors have been hit severely by stringent containment measures. Looking forward, a sustainable recovery will depend on the capacity of those sectors to adapt to the new environment and social distance rules, which will be the norm until the pandemic is under control. The research does not look at the impact of EU exit on the services sector. ${ }^{1}$ However, the findings may help inform an understanding of the impact at the end of the transition period.

This first section sets the scene, underlining the place of the services sectors in the UK economy and the nature of trade. It also provides insights on the likely impact of the coronavirus outbreak on services trade.

\section{The United Kingdom is a service-based economy}

\section{Services and the domestic economy}

Services account for a very large share of the UK economy (Figure 1). They represent about $80 \%$ of the economy both in terms of output and of employment (as compared to around $70 \%$ for employment and production on average in the OECD). The size of the services sector has been on an upward trend since the mid-1990s (Figure 2). It has stabilised since the financial crisis, when measured in terms of valueadded while it has continued to grow in terms of employment. Labour markets have proven quite resilient, but this has not materialised into stronger output. Although it is difficult to identify one factor behind the productivity weakness (this is the so-called UK productivity puzzle), subdued investment, low RD spending, a high share of low-skilled workers in the workforce and a lack of management skills have been put forward as important sources of the weakness (Mourougane and Kim, 2020). The share of the services sector in output and employment is now 7 to 10 times higher than those of manufacturing (Figure 3). Within the services sector, the share of financial services has been trending down since 2010 to reach $10 \%$ in terms of value-added and $3 \%$ in terms of employment.

\footnotetext{
${ }^{1}$ Recent OECD analysis estimates that UK exports and imports would decline by $6.1 \%$ and $7.8 \%$, respectively, as a result of the exit from the European Union (Arriola et al., 2020).
} 
Figure 1. Share of services in the UK economy, percentage, 2019

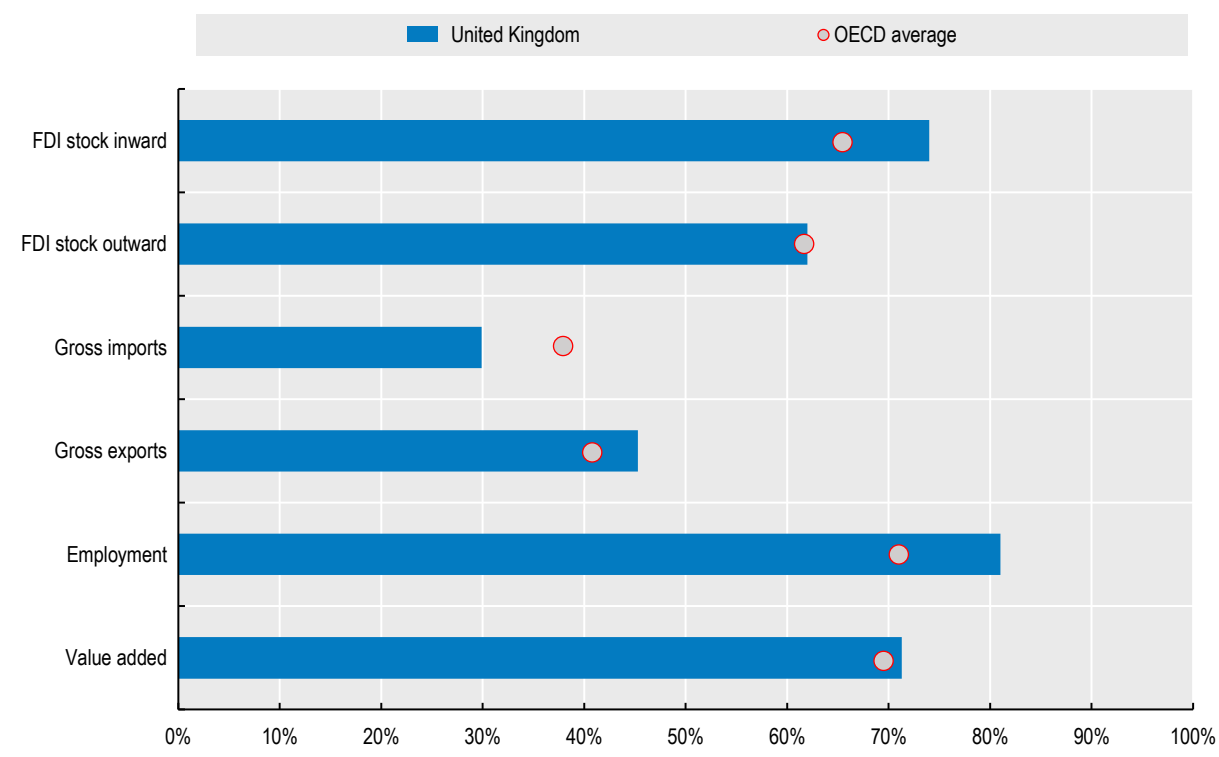

Note: Share of services in total value added, employment, gross imports and exports and FDI. Data for FDI are for 2018. Source: WDI, ILO, and OECD FDI.

Figure 2. Share of services in value added and employment in the United Kingdom, percentage, 1997-2019

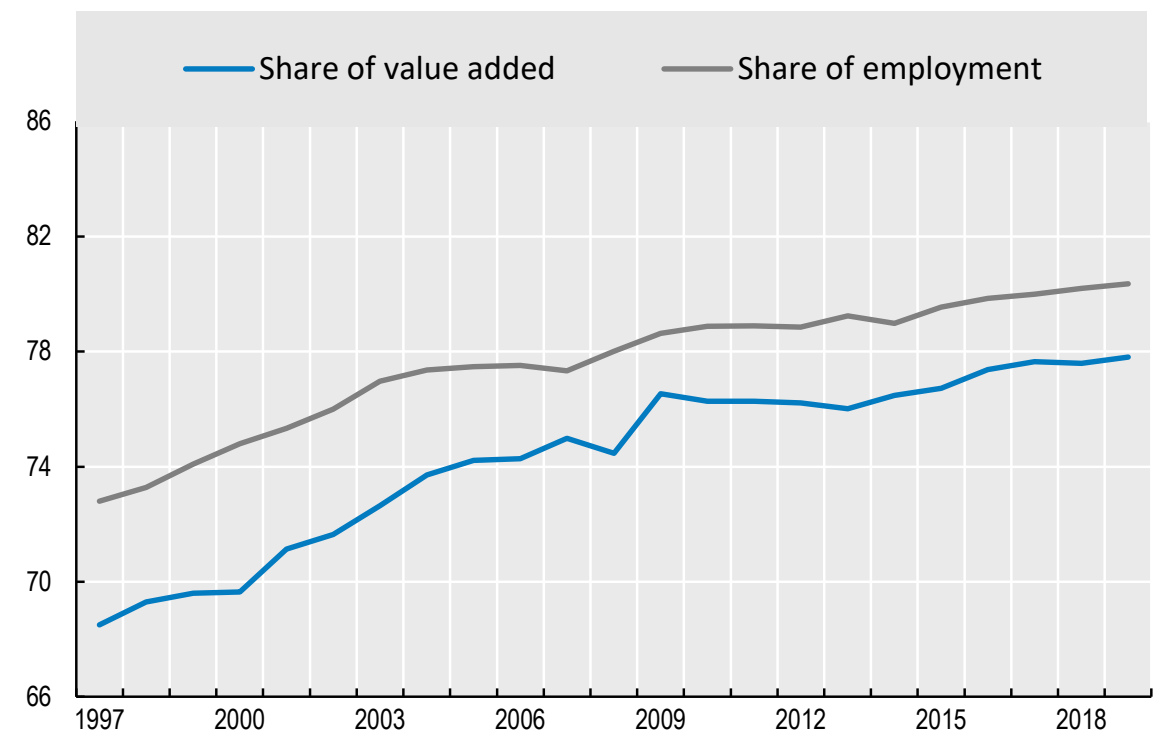

Note. Value added excludes imputed rents. Data refer to nominal gross value added.

Source: ONS (2020), "Quarterly National Accounts: October to December 2019", and "'Employment by industry", November 2020. 
Figure 3. Share of value-added and employment by sector, 2019

A. Employment

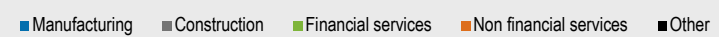

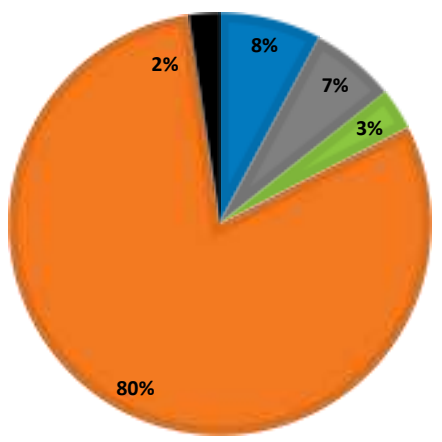

B. Value added

$\backsim$ Manufacturing $\backsim$ Construction $\backsim$ Financial services $\backsim$ Non financial services $\backsim$ Other

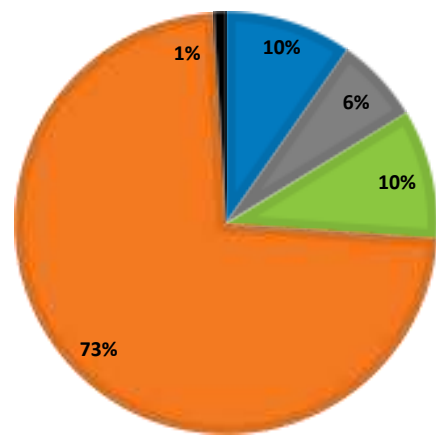

Source: ONS (2020), " ONS GDP Quarterly National Accounts, UK: January to March 2020" and "Employment by industry", November 2020.

The services sector has driven the recovery after the financial crisis (ONS, 2019). However not all services contributed to the same extent. The largest contributors were the scientific, professional and technical services and the real estate. By contrast, public administration and defence and financial and insurance activities are still below their pre-crisis level.

The services sector also plays a significant role in terms of investment, accounting for $62 \%$ of business investment in 2019 (Figure 4). This is a much more significant share than the manufacturing (15\%) or construction $(5 \%)$ sectors.

Figure 4. Business investment by sector, United Kingdom, 2019

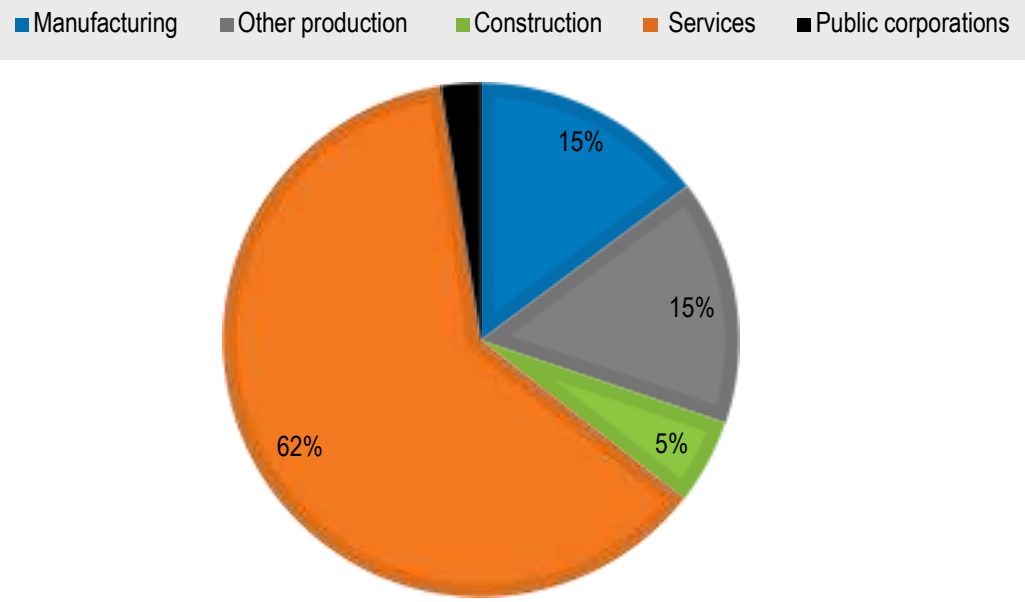

Note: Business investment is based on nominal gross fixed capital formation.

Source: ONS (2020), Business investment in the UK: October to December 2019 revised result, March 2020.

Business investment by industry and asset", March. 


\section{Services and international trade}

Services represent $46 \%$ of total exports, of which about a third is financial services (Figure 5). By contrast, services represent a lower share of the total of imports, around $30 \%$, with only $2 \%$ being financial services. The specialisation in services trade is deeper in the United Kingdom than in the average of OECD countries (Section 2). At the same time, the share of services in the total UK imports is close to the one observed in the average of OECD countries.

Figure 5. Share of goods and services in UK trade, 2019

\section{A. Share of goods and services in total exports 2019}

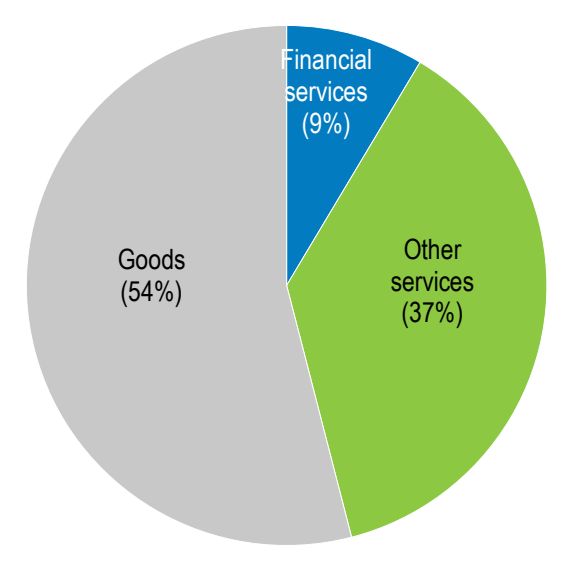

B. Share of goods and services in total imports 2019

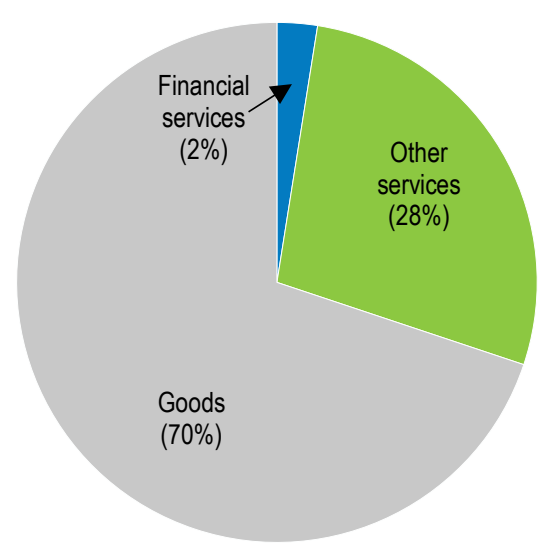

Source: ONS (2020), "UK Balance of Payments, The Pink Book: 2020".

Both imports and exports of services experienced an upward trend since 1995 in the United Kingdom (Figure 6). While the rate of increase was steady for services exports over the whole period, the pace of increase was initially slower for imports. Services exports continued to account for more than $60 \%$ of services trade. Since 2016, services exports and imports appear to grow in tandem. Since the outbreak of the COVID-19 crisis, both services imports and exports have collapsed. The fall was unprecedented and synchronised across countries (OECD, 2021) 
Figure 6. Services trade over time in the United Kingdom

A. GBP millions

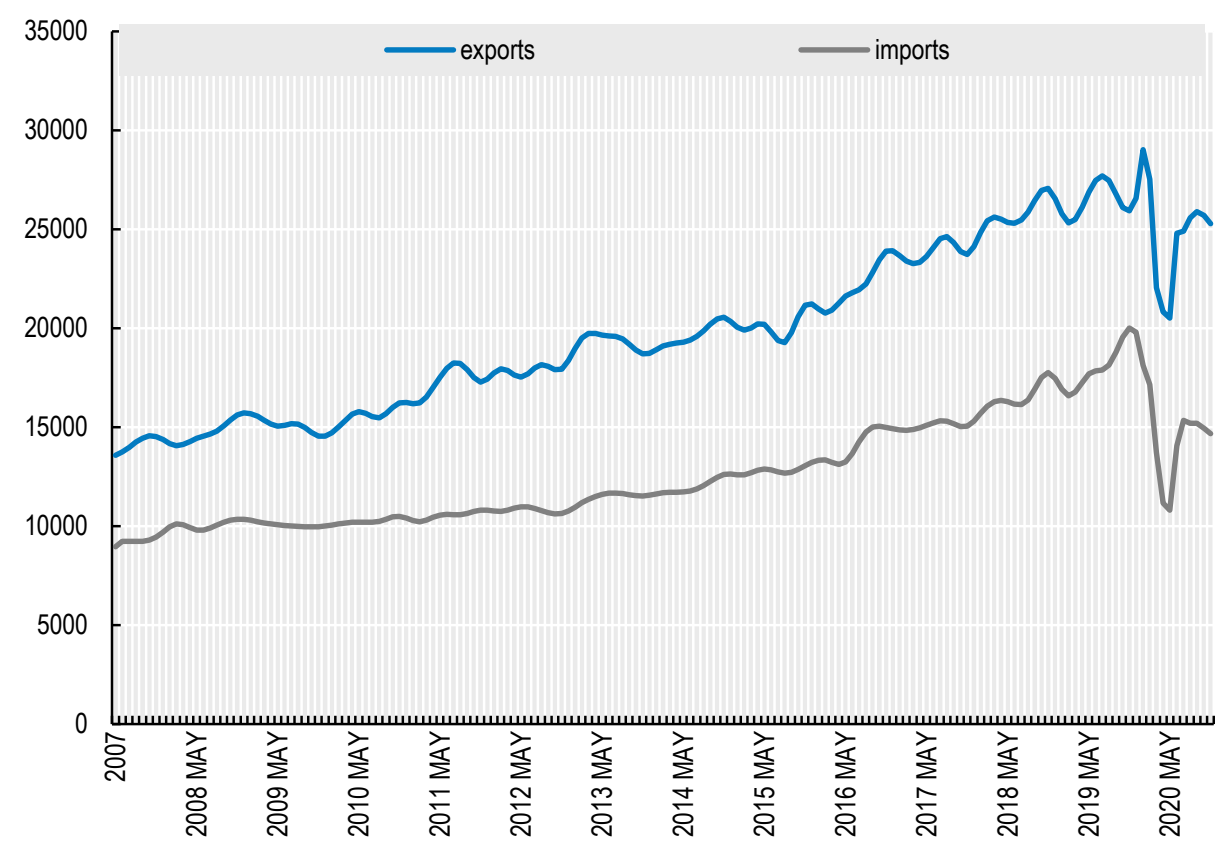

B. Year-on-year, percentage

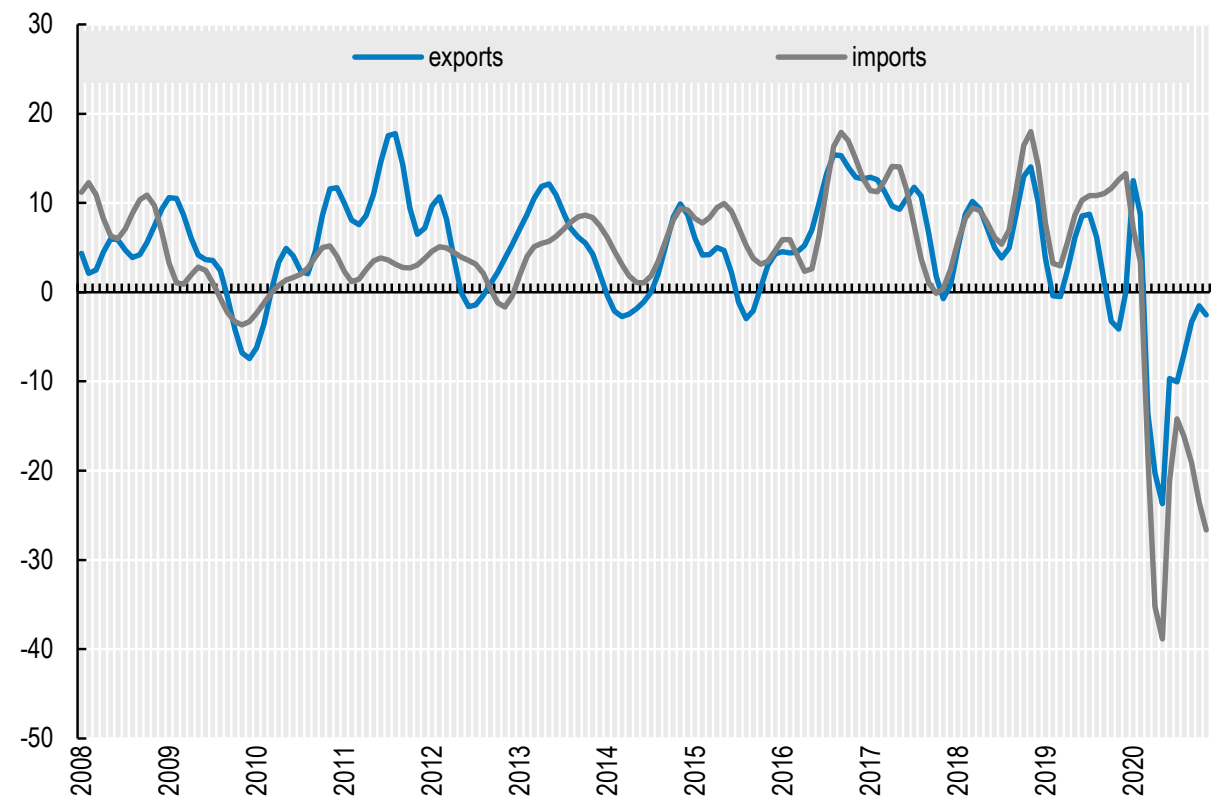

Source: ONS (2020), BOP data. 
Services trade has helped mitigate the large goods deficit. The UK current account amounted $1.3 \%$ of GDP in 2019, and was essentially explained by a large trade in goods deficit (4.3\% of GDP) while the country experienced a surplus in services trade (4.5\% of GDP). According to experimental data from the ONS, mode 1 (remote trade) accounted for a large share of service trade (Box 1).

\section{Box 1. Services trade modes of supply}

The definition of trade in services in GATS covers the four modes of supply. Distinctions among these modes are based on whether the service supplier and the consumer are present in the same country or different countries when the transaction occurs.

\section{Mode 1: Cross-border supply (remote supply)}

Cross-border supply takes place when a service is produced in one country but consumed in another one. Similar to traditional trade, when a good is delivered across a border both the supplier and the consumer remain in their respective countries. For example, a law firm may deliver legal advice by telephone or through the internet to a client overseas, or an individual from one country may purchase and download a computer game from a software firm residing in another country.

\section{Mode 2: Consumption abroad}

Consumption abroad takes place when services are consumed in the country where they are produced. The consumer or his/her property are abroad when the service is supplied. For example, a tourist may visit a museum while abroad or the property of a consumer, such as a ship, may be sent abroad to be repaired.

\section{Mode 3: Commercial presence}

Commercial presence takes place when a service supplier establishes a presence abroad in order to provide services. For example, a financial institution may open a branch in another country in order to provide financial services there.

\section{Mode 4: Presence of natural persons}

Presence of natural persons takes place when an individual is present abroad in order to provide a commercial service. The service is produced in the country where it is consumed. For example, an engineering consultant may travel abroad to oversee aspects of a building project or an employee of a software firm may be sent abroad to deliver information technology services.

According to experimental ONS data, Mode 1 made up $65 \%$ of total UK services exports and $55 \%$ of total services imports in 2019.

Source: Statistics Canada : https://www150.statcan.gc.ca/n1/pub/13-605-x/2018001/article/54966-eng, ONS (2020), Trade in Services by Modes of Supply, UK: 2019 
The structure of services trade has changed little since 2000 (Figure 7). Services exports and imports are essentially concentrated in few sub-sectors: transport, travel, financial and 'other business' services ${ }^{2}$. While the share of exports is more than twice the share of imports in financial services, the opposite is true for travel services. Exports and imports share of services are about the same for 'other business' and transport services.

\section{Figure 7. Composition of UK services exports and imports, percentage, 2019}

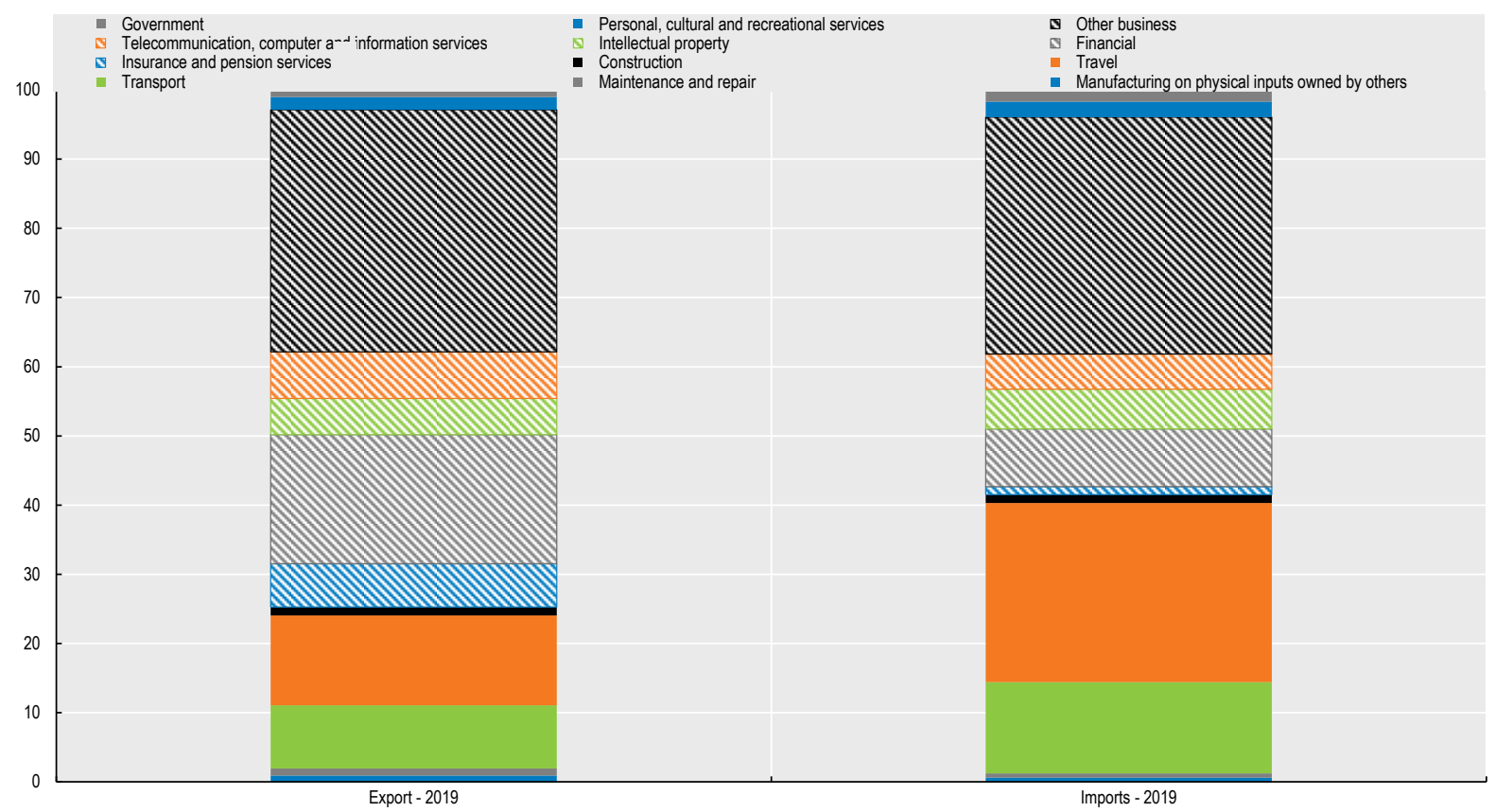

Source: ONS (2020) "UK Balance of Payments, The Pink Book: 2020".

\section{UK trade in services is concentrated with European countries}

EU countries represent the main trade partners of the United Kingdom, both in terms of goods and services (Table 1).

In 2019 , about $40 \%$ of UK services exports were directed to EU countries, and almost $49 \%$ UK services imports came from EU countries. Germany, France, Italy, the Netherlands, Spain and Belgium were the main partners, and the UK services balance was in surplus with all these countries but Spain. The United Kingdom experienced bilateral service trade deficits with a number of smaller European economies, for example Greece and Portugal, but the magnitude of this services trade deficit was generally small. Outside the European Union, Norway and Switzerland traded extensively with the United Kingdom.

Outside Europe, the United Kingdom benefited from a services trade surplus with most of the countries it has a close relationship with, in particular the United States. The United States appeared to be the principal services trade partner of the United Kingdom, with $25.4 \%$ of UK services exports and $20 \%$ of UK services imports going or coming from the United States in 2019. The UK services trade balances with some of the Gulf Arabian countries, China, and India was in deficit, though the United Kingdom trades less extensively with these countries than with the largest EU economies.

\footnotetext{
2 Amongst others, this category includes research and development services, professional and management consulting services, architectural, engineering, scientific, and other technical service as well as waste treatment and de-pollution, agricultural and mining services.
} 
Table 1. UK trade in services by partner country, 2019

\begin{tabular}{|c|c|c|}
\hline & UK exports to & UK imports from \\
\hline World Total (GBP, million) & 297419 & 192769 \\
\hline In terms of UK GDP (\%) & 14.3 & 9.8 \\
\hline Share of world total (\%) & 100.0 & 100.0 \\
\hline Europe & 48.0 & 56.6 \\
\hline Total EU28 & 38.9 & 48.8 \\
\hline \multicolumn{3}{|l|}{ of which } \\
\hline Belgium & 1.6 & 1.4 \\
\hline Denmark & 1.2 & 0.7 \\
\hline France & 5.0 & 6.6 \\
\hline Germany & 6.0 & 5.8 \\
\hline Ireland & 5.7 & 7.5 \\
\hline Italy & 3.2 & 2.6 \\
\hline Luxembourg & 1.6 & 1.5 \\
\hline Netherlands & 5.4 & 4.1 \\
\hline Spain & 2.9 & 6.8 \\
\hline America & 30.5 & 24.0 \\
\hline Canada & 1.8 & 1.2 \\
\hline United States & 25.4 & 20.1 \\
\hline Asia & 16.2 & 15.8 \\
\hline China & 1.7 & 1.1 \\
\hline Hong Kong, China & 1.3 & 1.3 \\
\hline India & 0.9 & 3.4 \\
\hline Japan & 2.3 & 2.6 \\
\hline Singapore & 1.4 & 1.8 \\
\hline Korea & 0.8 & 0.4 \\
\hline Gulf Arabian countries & 3.0 & 2.2 \\
\hline Australia & 2.3 & 1.2 \\
\hline Other & 5.4 & 3.6 \\
\hline
\end{tabular}

Source: ONS (2020), "UK Balance of Payments, The Pink Book: 2020 (Table 9.1).

\section{Regional distribution of services exports}

The large majority of UK cross-border services exports come from London. London accounts for more than $40 \%$ of total exports of services (Figure 8). The South East is also an important region for UK services exports, followed by Scotland, the North West and East of England. All other regions together only account for slightly more than $20 \%$ of total UK services exports. The sectoral composition of services exports is relatively homogeneous. Exports of financial and insurance services are of high importance throughout the United Kingdom (Table 2). The sector is among the top 3 exporting sectors in all regions, except the South East, Wales and Northern Ireland. Financial and insurance activities are the most important services export sector in eight regions. Transportation and storage activities are also an important sector for services exports throughout the United Kingdom. The sector figures in the top 3 in all regions except London and Northern Ireland. Professional, scientific and technical activities are the largest component of services exports in East of England and the South East, but they are also of high importance in the East Midlands, London, Scotland and Northern Ireland. Services exported by firms in the manufacturing sector account for the majority of services exports in Wales. Manufacturing firms are also important services exporters in the North East and Northern Ireland. Information and communication services are important export sectors in the West Midlands, London, the South East and Northern Ireland. In the South West, accommodation and food service activities are an important export sector. 
Table 2. Top 3 exporting services sectors by UK NUTS1 region, 2018

\begin{tabular}{l|l|l|l}
\hline \multicolumn{1}{c|}{ Region } & \multicolumn{1}{c|}{ Top 1 } & \multicolumn{1}{c}{ Top 2 } & \multicolumn{1}{c}{ Top 3 } \\
\hline North East & Financial and insurance activities & Manufacturing & Transportation and storage \\
\hline North West & Financial and insurance activities & Transportation and storage & Other services \\
\hline $\begin{array}{l}\text { Yorkshire and } \\
\text { The Humber }\end{array}$ & Financial and insurance activities & Transportation and storage & $\begin{array}{l}\text { Professional, scientific and technical } \\
\text { activities }\end{array}$ \\
\hline East Midlands & Financial and insurance activities & $\begin{array}{l}\text { Professional, scientific and technical } \\
\text { activities }\end{array}$ & Transportation and storage \\
\hline West Midlands & Financial and insurance activities & Information and communication & Transportation and storage \\
\hline East of England & $\begin{array}{l}\text { Professional, scientific and } \\
\text { technical activities }\end{array}$ & Financial and insurance activities & Transportation and storage \\
\hline London & Financial and insurance activities & Information and communication & $\begin{array}{l}\text { Professional, scientific and technical } \\
\text { activities }\end{array}$ \\
\hline South East & $\begin{array}{l}\text { Professional, scientific and } \\
\text { technical activities }\end{array}$ & Information and communication & Transportation and storage \\
\hline South West & Financial and insurance activities & $\begin{array}{l}\text { Accommodation and food service } \\
\text { activities }\end{array}$ & Transportation and storage \\
\hline Wales & Manufacturing & Other services & Transportation and storage \\
\hline Scotland & Financial and insurance activities & $\begin{array}{l}\text { Professional, scientific and technical } \\
\text { activities }\end{array}$ & Transportation and storage \\
\hline Northern Ireland & Information and communication & Manufacturing & $\begin{array}{l}\text { Professional, scientific and technical } \\
\text { activities }\end{array}$ \\
\hline
\end{tabular}

Source: ONS International trade in services by subnational areas of the United Kingdom, 2018.

\section{Digital trade is increasingly important}

At $42.5 \%$, the share of services export that can be potentially delivered digitally is one of the highest amongst OECD countries (Figure 11). It is significantly higher than the OECD average (33\%). The share of digital exports of financial services is particularly high (24\%), much larger than those of Switzerland $(17 \%)$ and the United States (14\%). On average the remaining OECD countries experience a rate close to $3 \%$. By contrast, the share of digital trade related to charges for intellectual property use not included elsewhere or telecommunications, computer and information services lags in the United Kingdom. It is below the OECD average and significantly lower than in the best-performing countries.

ONS experimental data on services that are actually, rather than potentially, digitally delivered provides complementary information (ONS, 2020c). In particular, the data show that remote supply (mode 1) amounted to $65 \%$ for services exported via mode 1, 2 and 4 and $22 \%$ of services supplied through all modes. Approximately $55 \%$ of trade in services was estimated to be imported (excluding mode 3 ) by remote means. The three services that had the highest proportion of imports supplied remotely were intellectual property $(95 \%)$, telecommunications $(83 \%)$, and transportation $(80 \%)$. 
Figure 8. Exports of potentially digitally-delivered services, percentage of total services exports, 2019

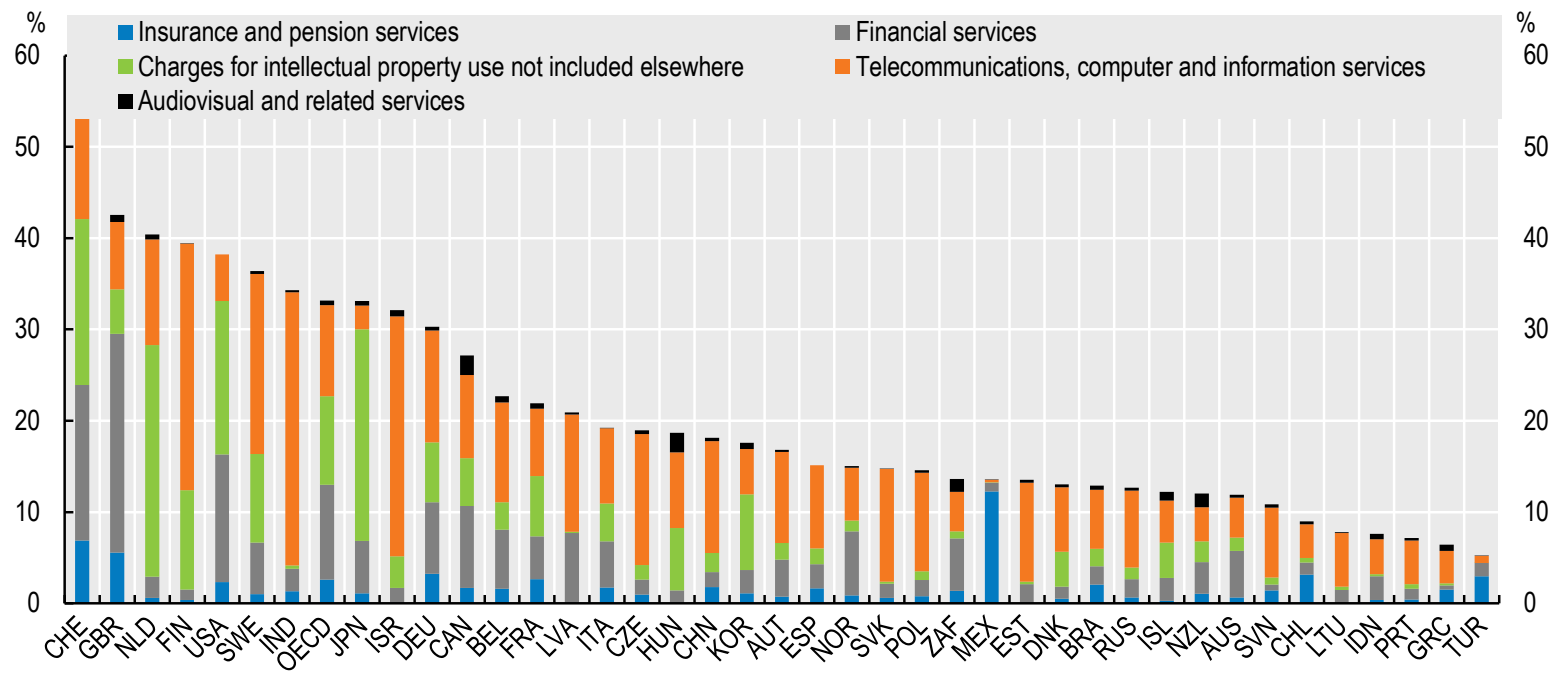

Source: OECD (2019), Going Digital: Shaping Policies, Improving Lives.

\section{Services and international trade in value added terms}

Services spill over into all the other parts of the economy (Miroudot and Cadestin, 2017). Services value added amount to $70 \%$ of gross exports in the United Kingdom. This is second-highest share in OECD countries (Figure 9). Most of the value added is domestic.

Figure 9. Services value added share of gross exports, 2016

Percentage

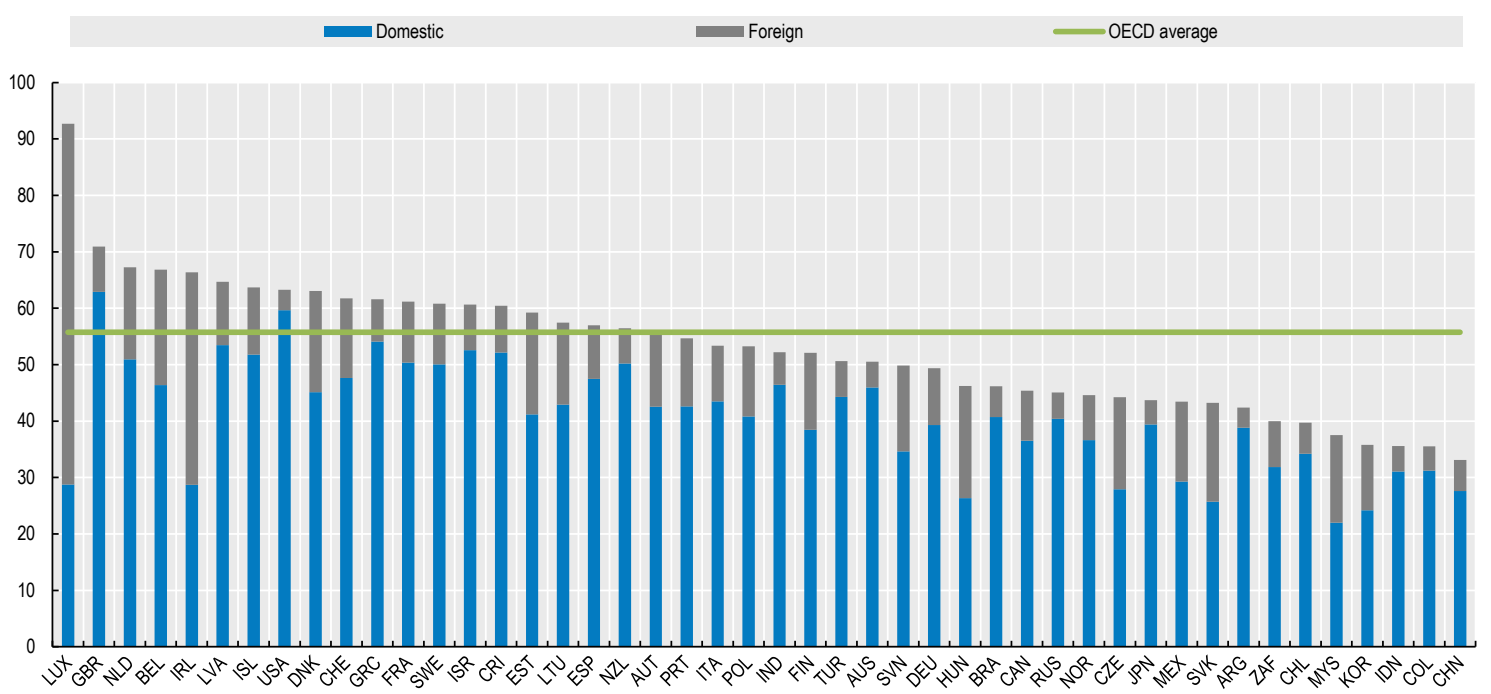

Source: OECD TIVA database. 
Services can also be embodied in a country's manufacturing exports. In the United Kingdom, around a third of value added embodied in manufacturing exports comes from services sectors. Distribution services, 'other business' services, financial services and transport services are the most important contributors to manufacturing exports (Figure 10). Around one-third of all services value added embodied in UK manufacturing exports come from abroad.

Figure 10. UK services content of gross exports of manufacturing industries, 2016

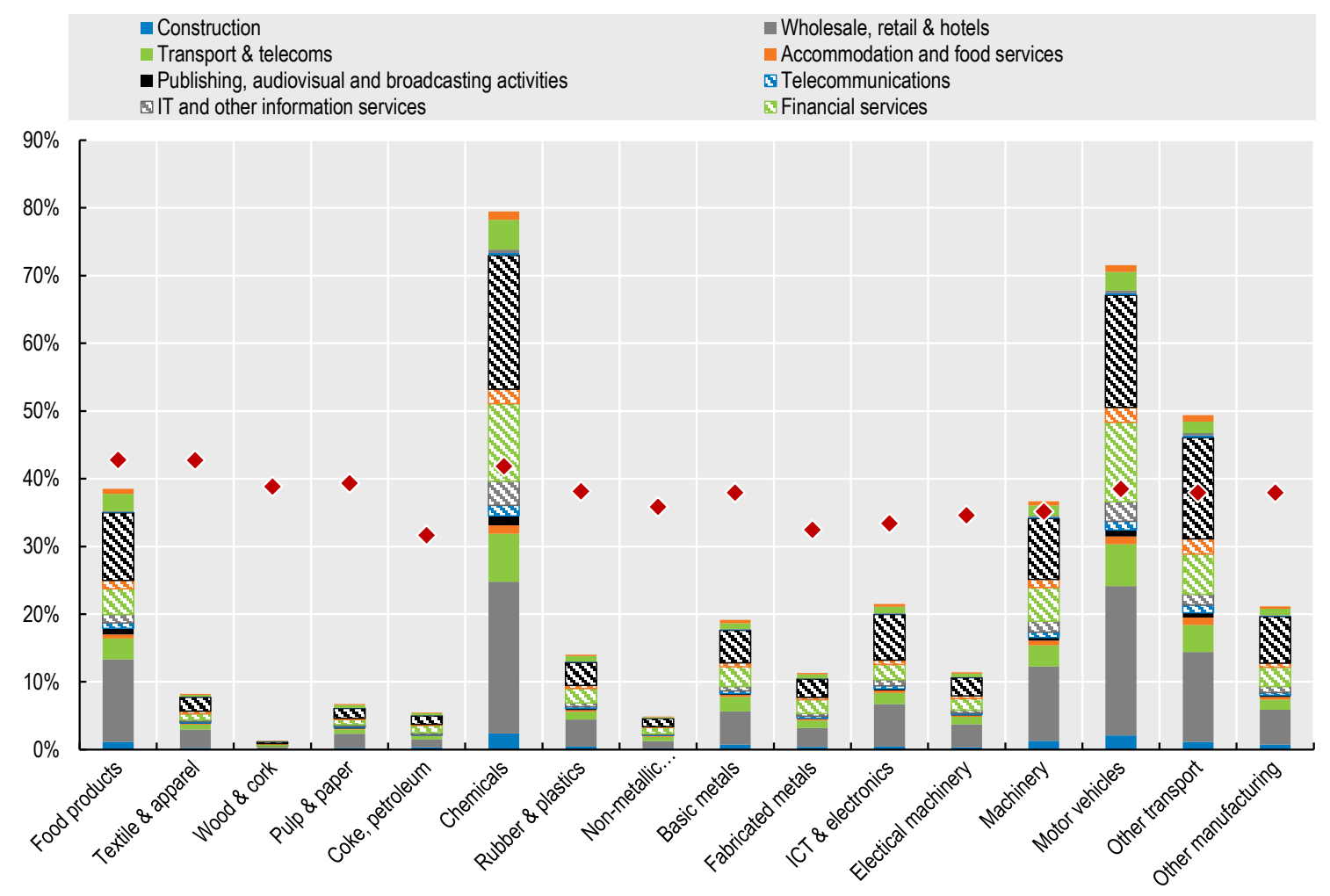

Source: OECD TiVA database.

The characteristics of services value added in manufacturing exports in the United Kingdom is comparable to those of other major OECD economies such as France or Italy (Figure 11). Services also account for a similar share of manufacturing exports in the United States and Australia, albeit with a higher relevance of domestic services rather than foreign services. Services are less important for the manufacturing sectors in Germany and Japan. In Germany, services value added in manufacturing exports has fallen markedly since 2005. By contrast, services are much more important for manufacturing exports in the small economies of Ireland and the Netherlands. The manufacturing sectors of these countries particularly rely on foreign services, imported from their larger neighbours, including the United Kingdom. Foreign services are also important relative to domestic services in Canada, due to its proximity to the United States.

These services embodied in manufactured goods can be important determinants of export competitiveness. While most of these are domestic services, firms also use offshoring of services to boost their productivity. In the United Kingdom, services offshoring is particularly important for manufacturing exports. This highlights that barriers to services imports can have detrimental effects on the manufacturing sector in the United Kingdom. 
Figure 11. Share of services value added in manufacturing exports, selected countries, 2005-2015

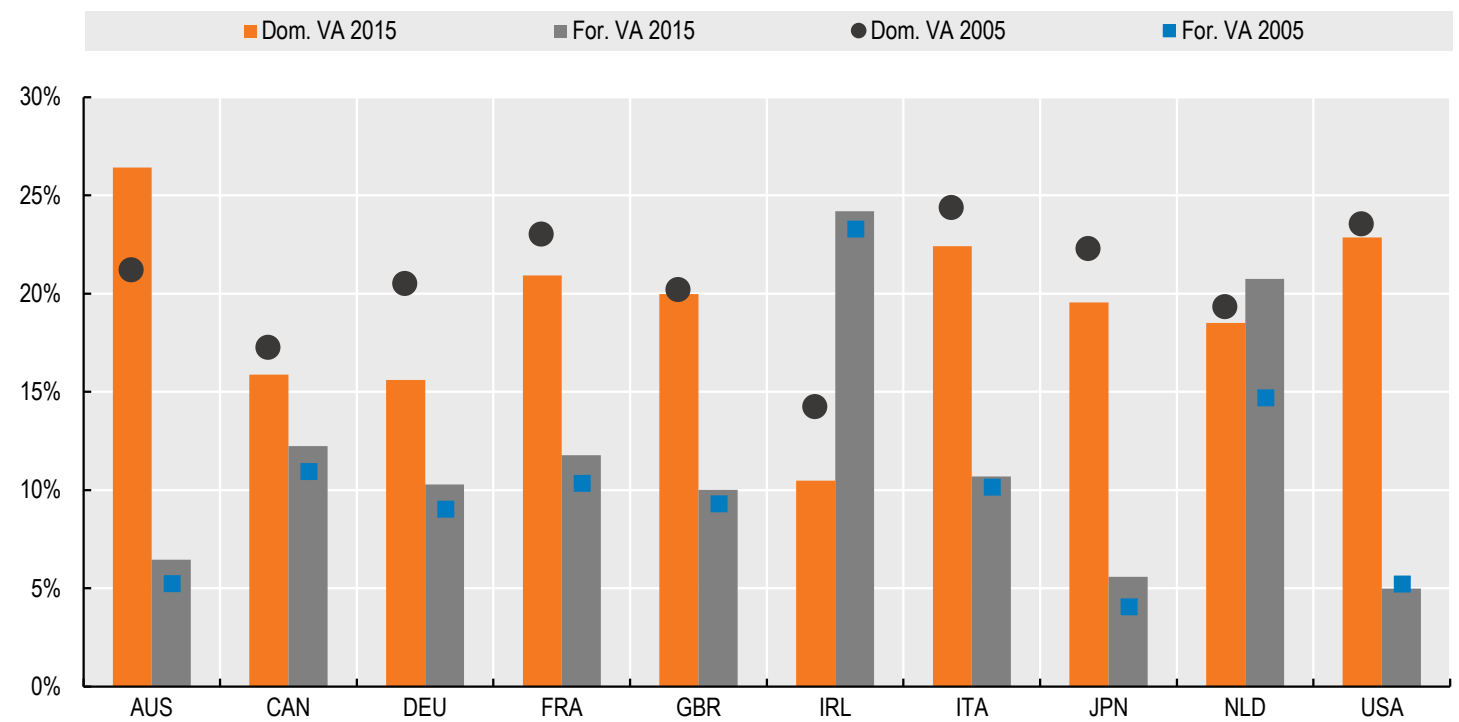

Source: OECD TiVA database.

\section{Although beneficial, international investment is slowing}

\section{Foreign direct investment}

The United Kingdom displayed lower inflows and outflows of foreign direct investment than the OECD average (Figure 1). The difference in terms of inward FDI flows is likely to have increased as there is evidence of a marked fall in transactions from EU countries to the United Kingdom (Breinlich et al., 2019).

Companies with inward FDI links had higher employment per business, value added and productivity than those without FDI links in the services sectors in 2018 (Figure 12; ONS, 2019). UK companies with FDI links accounted for $30.3 \%$ of UK employment in 2018 despite representing $2.1 \%$ of all UK businesses. Services firms with FDI links generated almost 25 times more value added and were 1.8 times more productive than firms without links.

Figure 12. Productivity in UK services firms with and without FDI links, 2018, GBP thousand

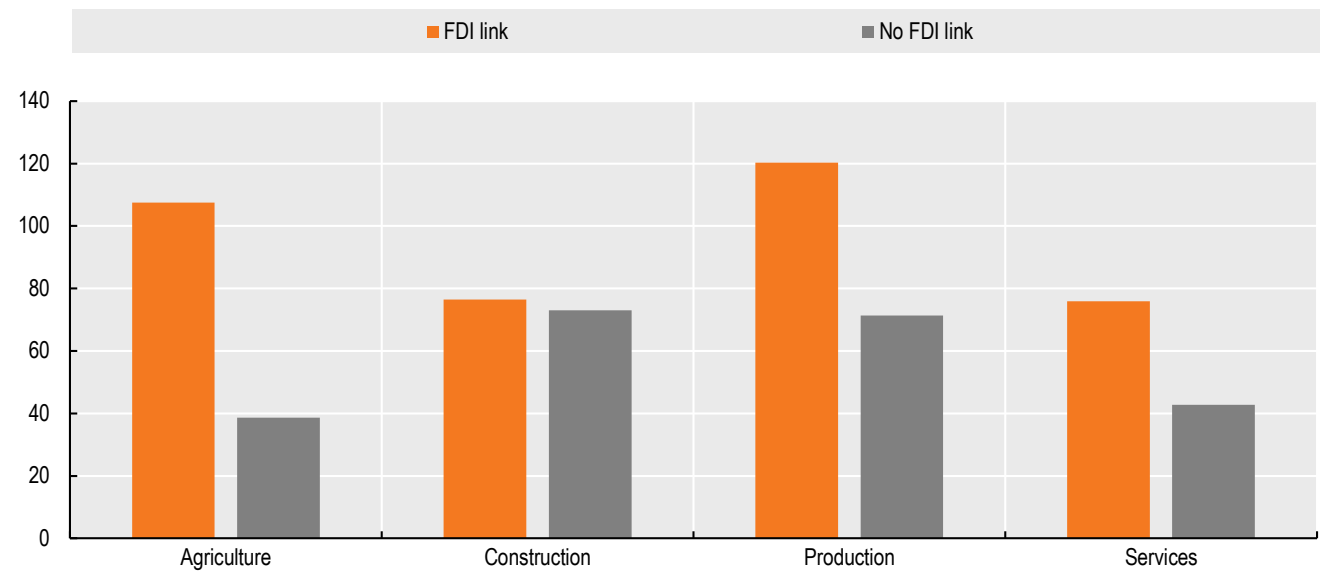

Note: Productivity is measured as GVA per worker.

Source: ONS (2020), UK Foreign Direct Investment, Trends and Analysis: August 2020. 


\section{Commercial presence of businesses in foreign markets (Mode 3)}

Compared to the OECD average, the United Kingdom is a strong exporter of Mode 3 services, which require the commercial presence of businesses in foreign markets via the establishment of foreign affiliates (Figure 13). Sales of these affiliates in their host country correspond to the host country's Mode 3 services imports. Similarly, they correspond to Mode 3 services exports of the country where the ultimate owner of these affiliates is established. The ratio of exports to domestic output in the United Kingdom is much larger than the OECD average of all commercial services, but also in key sectors such as telecommunications \& ICT or finance \& insurance. For example, sales of UK affiliates abroad are around half of domestic sales in the sector. For telecommunications and ICT, the ratio of Mode 3 exports to domestic sales is around $40 \%$.

The importance of Mode 3 services exports is relatively small in most other sectors. In 'other business' services, transport, accommodation \& food, wholesale \& retail trade and construction, Mode 3 exports amount to less than $20 \%$ of domestic sales.

Figure 13. Mode 3 services exports relative to domestic sales in the United Kingdom and in the OECD, 2016

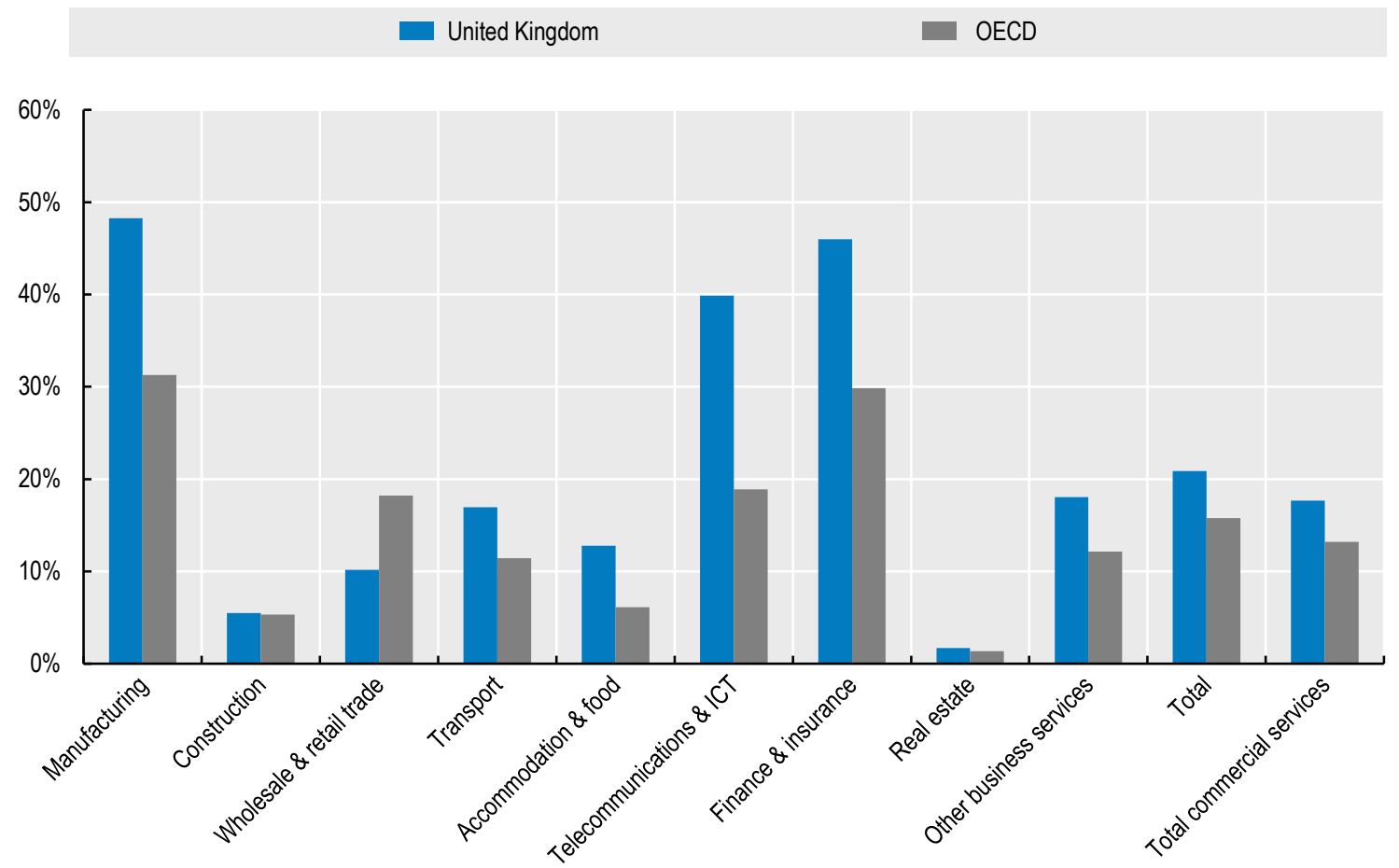

Note: Foreign sales of multinational enterprises as a share of domestic sales in the same sector.

Source: OECD Analytical AMNE database.

\section{Looking forward, the COVID-19 crisis is likely to have a significant impact on services trade}

The coronavirus outbreak has triggered a massive policy response, leading to a complete lockdown of many sectors in the United Kingdom and internationally. Resulting output losses are expected to be substantial, and global trade has decelerated rapidly. While services trade proved to be resilient in the aftermath of the 2008 financial crisis, the health measures that were put in place to slow the propagation of the virus led to a dramatic decline in sales and productions of many services sectors (Bloom et al., 2020). 
The impact of the crisis will vary markedly across services sectors (OECD, 2020a). With the almost global travel bans and lockdown of non-essential activities, transportations, tourism and sectors that require face to face interactions have been affected significantly. Several factors are likely to dampen services trade flows:

- A marked fall in demand, as firms and households were locked down.

- Some decline in productivity as firms and workers had to adapt to a new environment, and in supply as firms production is constrained.

- Restrictions on movement of people are expected to trigger a rise in trade costs (Box 2). While those measures have been justified for health reasons, they could un-necessarily hamper business travel and limit the flow of international students in the United Kingdom. The latter could be particularly detrimental to research and university funding.

- Border measures and logistical inefficiencies can also increase services costs.

In the short term, balance of payment data suggest all OECD countries experienced a collapse in services trade at the onset of the COVID-19 crisis, during the period February-April 2020 (Figure 14). Evidence suggest that travel ban restrictions, together with a depressed international environment and domestic restriction (in particular lockdowns) have been important factors behind these developments. Travel and tourism were particularly affected (Mourougane, Jaax and Gonzales, 2021). Those sectors are expected to recover, albeit at a relatively slow pace.

\section{Figure 14. Services trade collapse at the start of the COVID-19 crisis}

Annualised month-on-month percentage change, average February to April 2020

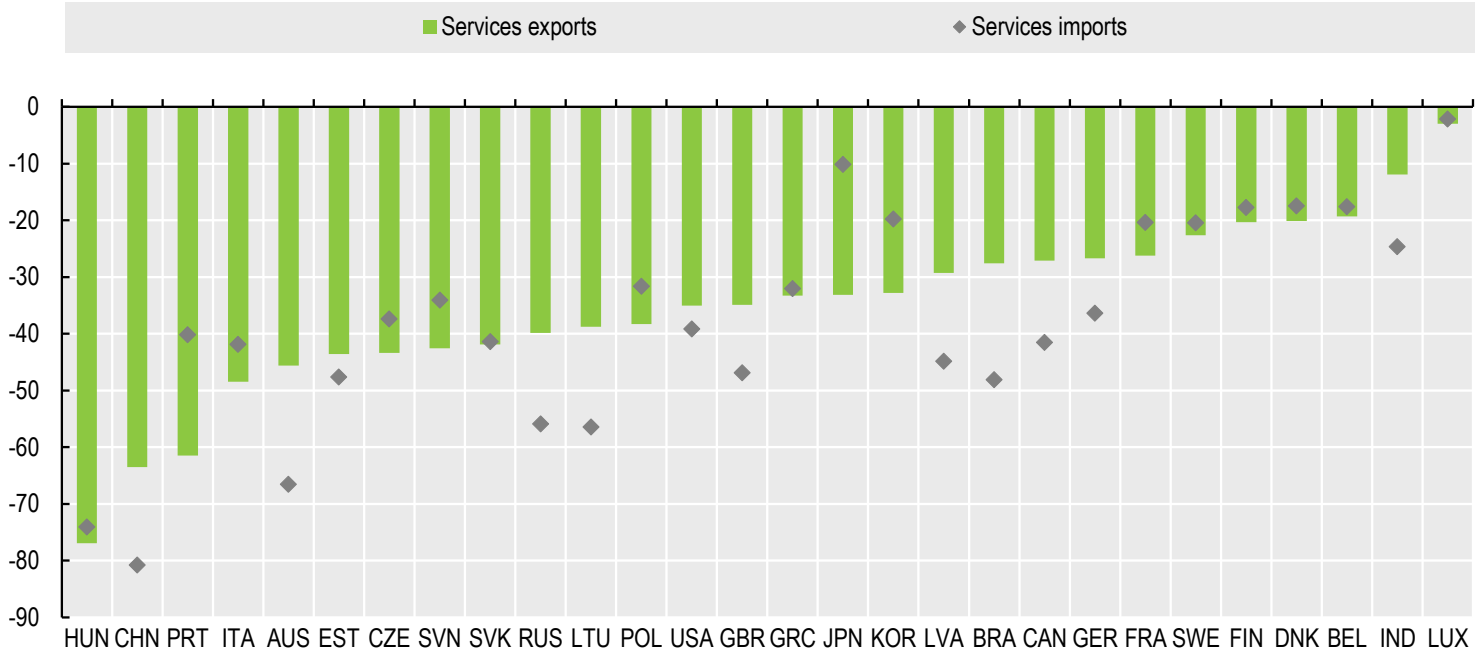

Source: Calculations using balance of payments data.

The May 2021 Economic Outlook projects that the UK real GDP could grow by $5.8 \%$ to $4.4 \%$ in $2021-22$, after $-3.5 \%$ in 2020 . The recovery would be uneven within the OECD, with the United States expected to grow at a much faster rate than Europe and Japan. Real GDP in United Kingdom is expected to rebound strongly to $7.5 \%$ in 2021 and $5.5 \%$ in 2022, from the $9.8 \%$ fall in 2020 (OECD, 2021c). Trade flows would only slowly and partially recover in the coming years, as the United Kingdom has left the European Union.

Over the medium term, simulations using the OECD general equilibrium trade model METRO suggest that UK services imports and exports could decline significantly in the aftermath of the COVID-19 crisis, by 
respectively $4.4 \%$ and $3.9 \%$ in the medium term on average across services sectors (OECD, 2020b; Figure 15). The fall in demand is expected to be the most important driver, accounting for $3 / 5$ of the fall in imports and almost $2 / 3$ of the fall in exports in the services sectors. The declines will be particularly pronounced in the hospitality sector reaching $7 \%$ to $8 \%$.

Teleworking can minimise the potential impact. For example, in the information and communication industry $53 \%$ of employees reported to ever having worked from home in 2019 , compared to $10 \%$ of employees within the accommodation and food services industry (ONS, 2020). Although this survey does not measure the extent to which workers have effectively teleworked, it gives an indication on the likelihood of teleworking in certain sectors. Consumer preferences could also change permanently, accentuating the digital transition towards greater use of e-commerce and the digital delivery of services. Assessment of these effects remain challenging as evidence is currently lacking on whether consumer and producer changes in behaviour will persist overtime.

Figure 15. Impact of the COVID-19 crisis on trade flows in the United Kingdom, difference to baseline, percentage

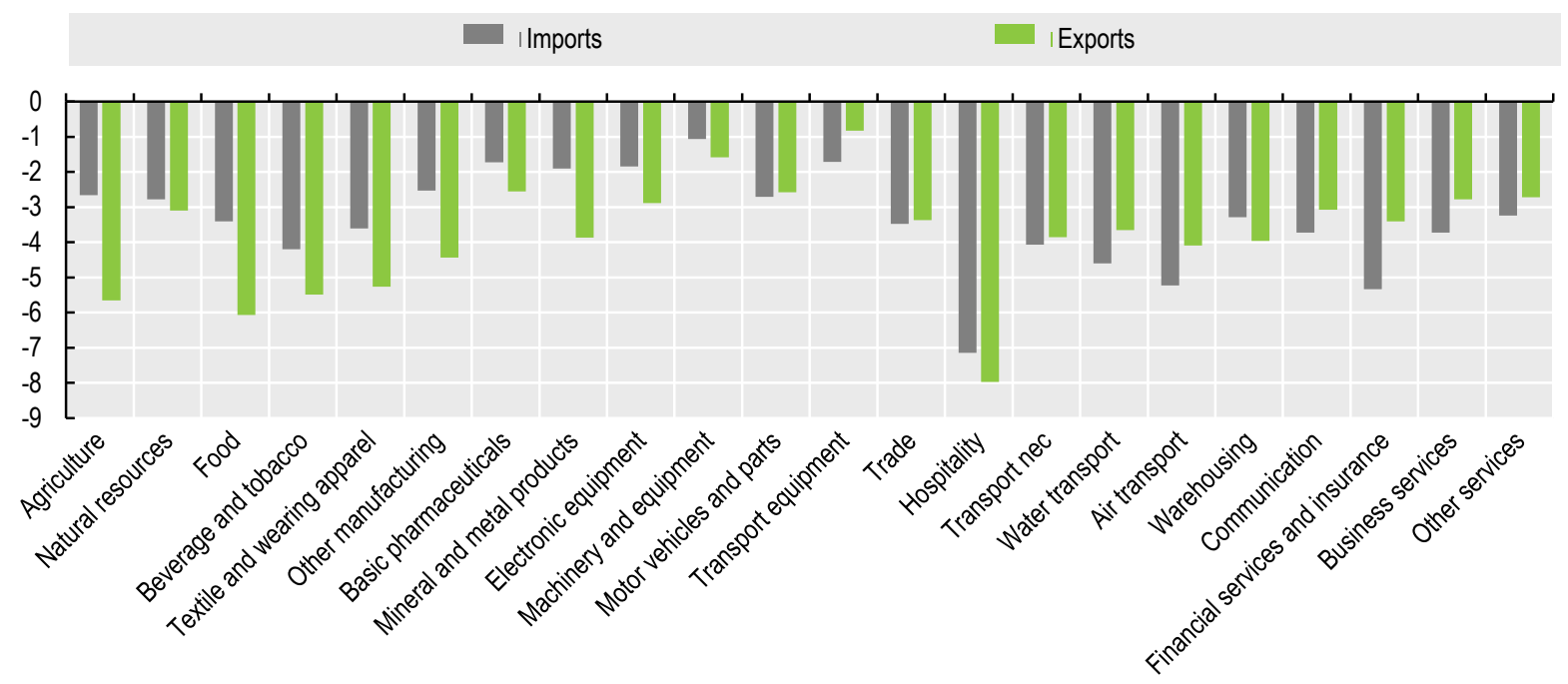

Note: This calculation is consistent with the single-hit scenario of the June 2020 Economic Outlook.

Source: OECD METRO model.

The pace and the strength of the recovery is expected to vary markedly across services sectors. The health crisis could linger for months or years and any activity that involves person to person engagement especially hospitality, retail, tourism, cultural activities - is likely to be depressed for a long period of time. The speed of the recovery in air transport will depend on how long passenger travel will be banned or restricted for. More generally, one major determinant of the recovery of services trade will be related to the pace at which governments will wind down the trade restrictions which were imposed to contain the pandemic or trade barriers that pre-exist the crisis, which for services trade are largely behind-the-border regulatory requirements (OECD, 2021). In particular, trade restrictions on digital trade are likely to have an even more pronounced effect than in the past as social distancing rules are put in place. 


\section{Box 2. Travel bans and rise in services trade costs}

This box quantifies the services trade costs associated with an illustrative scenario where all the countries are assumed to close their borders to passengers, but leave freight trade open. Drawing on the OECD COVID-19 policy tracker and the OECD Services Trade Restrictiveness Index (STRI) database, a set of recent regulatory changes affecting business travel and labour mobility was identified. The outcomes were subsequently translated into trade costs, expressed as a percentage of trade values, following Benz and Jaax (2020).

Several types of measures are considered.

- In the first step, conditions on business travel are assumed to become more restrictive. These include the time and costs to deliver visas, the time taken for customs clearance, and other restrictions on business travels. Only measures regarding visas of passengers have been made more restrictive. Visa procedures for transport crews remain unchanged. This is consistent with the fact that policies have aimed to restrict passenger traffic, while leaving freight traffic unchanged.

- In a second step, quotas on intra-corporate transferees have been set to zero, in addition to the measures considered in the first step.

- In a third step, sector-specific measures have been put in place. These are related to measures on mutual recognition of qualifications, temporary licensing, or residency requirements, which have been rendered more difficult or impossible by the restrictions on passenger travel.

Trade costs on services are estimated to increase by an average of $12 \%$ across sectors and countries in the medium term. The impact would be lower, at $8 \%$ on average across sectors, in the United Kingdom (Figure 16).

The analysis identifies a large variability in the increase in services-trade costs across sectors, reflecting the stringency of initial regulations and the relative importance of business travel and labour mobility to international services trade in the United Kingdom:

- Across countries, the United Kingdom would experience the second lowest increase in trade cost, after Poland.

- Trade costs for professional services are found to increase by around $9 \%$ to $13 \%$, and vary across professions depending on the pre-existing degree of openness.

- Trade costs in logistics services and in telecommunication and courier services could jump by around $5 \%$ to $8 \%$.

- Trade costs could rise by $3 \%$ to $6 \%$ across transport modes, reflecting the fact that transport is more capital intensive than other services sectors 
Figure 16. Trade costs arising from the passenger travel bans, percentage of trade values

A. By country, average across services sectors

$$
\diamond \text { Trade cost }
$$

- Lower band

$\Delta$ Upper band

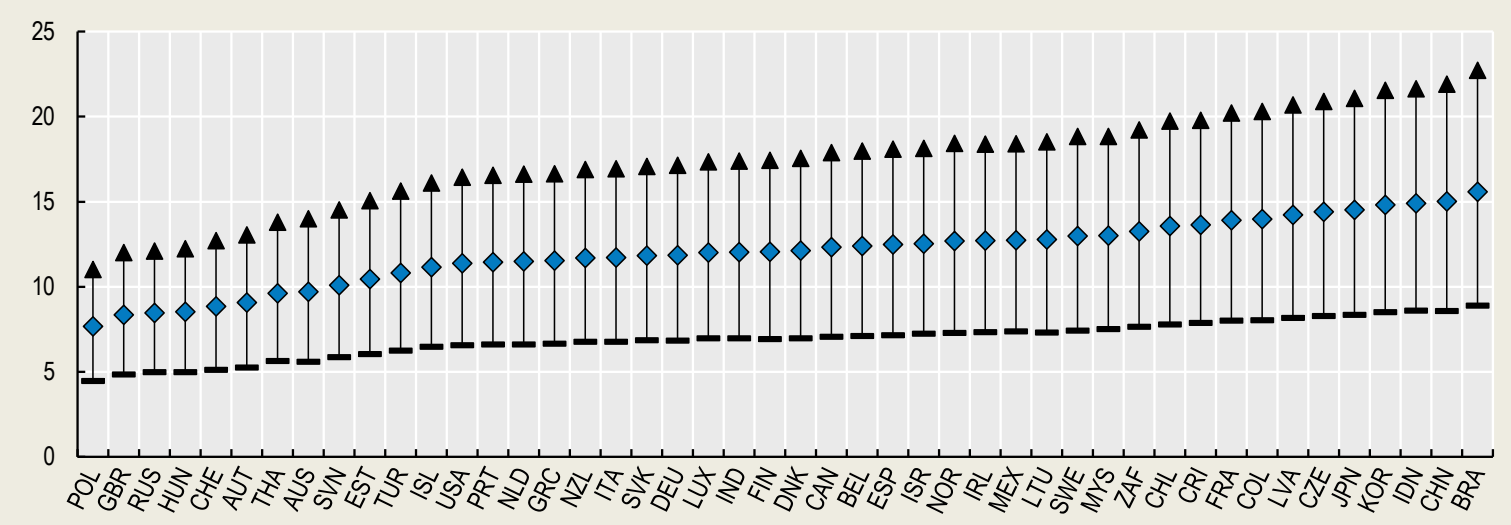

B. By sector, United Kingdom
$\diamond$ Trade cost
- Lower band
$\Delta$ Upper band

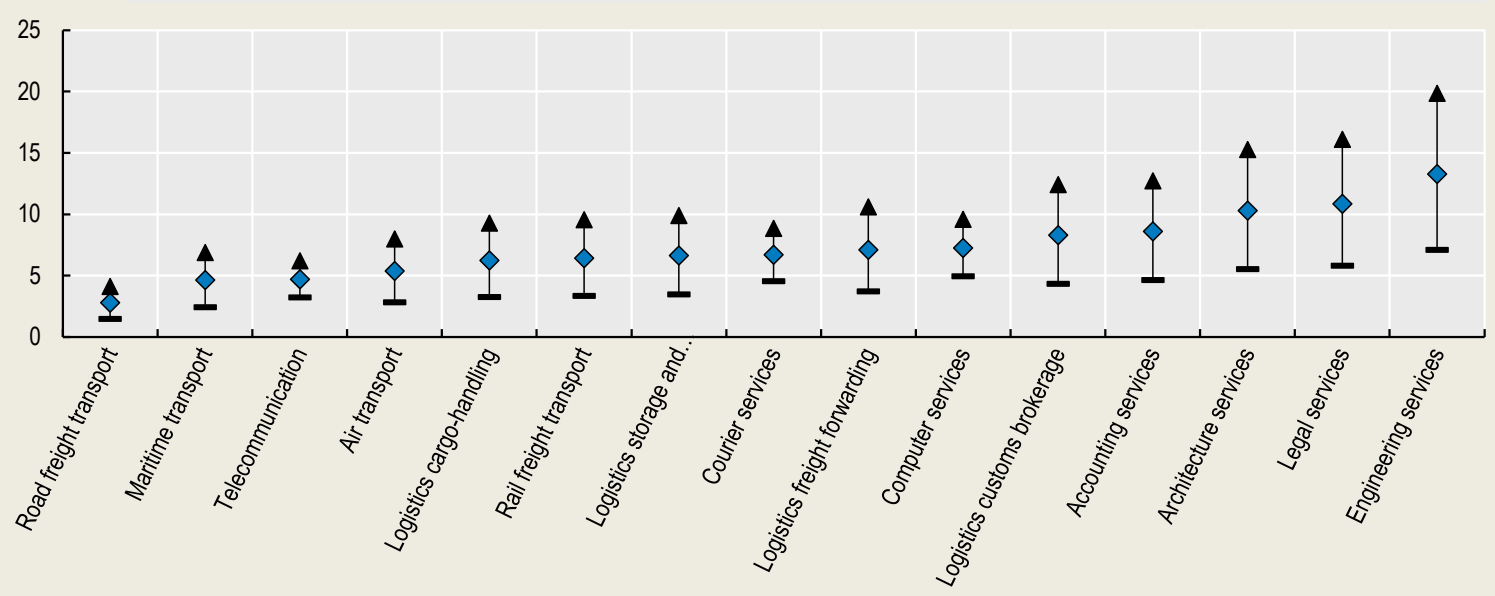

Note: Ninety per cent confidence bands are computed using standard errors around estimates of trade elasticities.

Source: Benz, Gonzales and Mourougane (2020). 


\section{References}

Arriola, C., S. Benz, A. Mourougane and F. van Tongeren (2020), "The trade impact of the UK's exit from the EU Single Market", OECD Economics Department Working Papers, No. 1631, OECD Publishing, Paris.

Benz S. and A. Jaax (2020), "The Cost of Regulatory Barriers to Trade in services: New Estimates of ad valorem Tariff", OECD Trade Policy Papers, OECD Publishing, Paris.

Benz, S., F. Gonzales and A. Mourougane (2020), "The Impact of COVID-19 international travel restrictions on services-trade costs", OECD Trade Policy Papers, No. 237, OECD Publishing, Paris.

Breinlich H., E Leromain, D. Novy and T. Sampson (2019), "Voting with their Money: Brexit and outward Investment by UK Firms", CEP Brexit Analysis No. 13, Centre for Economic Performance, London School of Economics.

Bloom N., F. Guvenen and S. Salgado (2020), "COVID-19: The skewness of the shock”, VOXeu, 5 May. Jaax, A., F. Gonzales and A. Mourougane (2021), "Nowcasting aggregate services trade", OECD Trade Policy Papers, No. 253, OECD Publishing, Paris, https://doi.org/10.1787/0ad7d27c-en.

Mourougane A., A. Jaax and F. Gonzales (2021), "COVID-19, international mobility and trade in services: The road to recovery", OECD Policy Responses to Coronavirus (COVID-19) https://doi.org/10.1787/ec716823-en.

Lassmann, A. and F. Spinelli (2020), "Services trade and labour market outcomes in the United Kingdom", OECD Trade Policy Papers, No. 243, OECD Publishing, Paris.

Mourougane, A. and E. Kim (2020), "Boosting productivity in the United Kingdom's service sectors", OECD Economics Department Working Papers, No. 1629, OECD Publishing, Paris.

OECD (2021a), "COVID-19, international mobility and trade in services: The road to recovery", OECD Policy Brief.

OECD (2021b), OECD STRI: Policy trend up to 2021, OECD Publishing, Paris.

OECD (2021c), Economic Outlook, May.

OECD (2020a), OECD Economic Survey for the United Kingdom, October.

OECD (2020b). "Policy Brief: Shocks, risks and global value chains: Insights from the OECD METRO model," OECD Publishing, Paris.

ONS (2019a), Services Sectors UK: 2008 - 2018.

ONS (2019b), UK foreign direct investment, trends and analysis, July 2019.

ONS (2020a), Technology intensity and homeworking in the UK, May.

ONS (2020b), Trade in services by modes of supply, UK: 2019. 


\section{UK services performance and competitiveness}

This section examines UK services performance and competitiveness in more depth looking at its evolution overtime and compared to its main trading partners along several dimensions.

\section{The United Kingdom demonstrates dynamic growth in services trade}

Services exports have grown rapidly in the OECD since 2012 up until the COVID-19 crisis. The value of services exports ${ }^{3}$ increased by around 25\% between 2012 and 2019, with most of the growth in the first two years and a small dip in 2015 (Figure 17). Growth rates of services trade appear particularly remarkable in comparison with the moderate expansion of trade in goods during the same period. OECD countries' merchandise exports only reached an aggregate growth of 7\% between 2012 and 2019 or around $1 \%$ annual growth. UK goods exports were even less dynamic at the same time with a total increase of only $2 \%$.

Growth of cross-border services exports in the United Kingdom between 2012 and 2019 closely followed the OECD trend. Among the largest OECD economies, Japan experienced the most dynamic growth, managing to expand their services exports by around 40\%. Among the smaller OECD countries, top performer Ireland doubled its services exports in only seven years. The Netherlands also boast strong growth of services exports. The United States and France performed on par with the OECD average. Services export growth was less dynamic in Australia and Italy.

Figure 17. Services export growth in selected OECD countries, 2012=100, 2012-2019

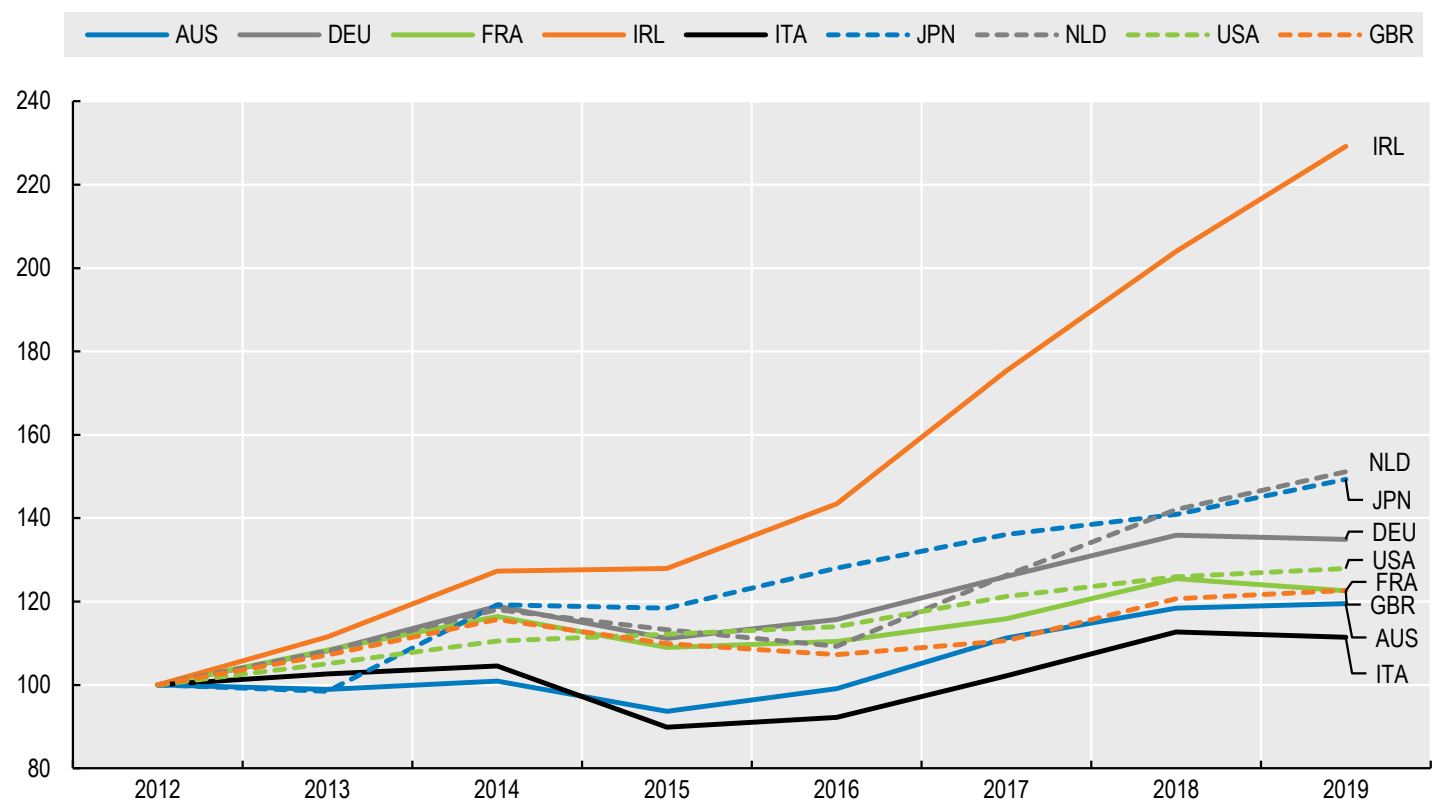

Source: OECD-WTO Balanced Trade in Services (BaTIS) data, reported values.

\footnotetext{
3 This analysis refers to cross-border services trade as recorded in the balance of payments, defined as transactions between residents and non-residents according to the Manual on Statistics of International Trade in Services 2010.
} 
During the same time, the United Kingdom experienced faster growth of services imports than most other large OECD countries (Figure 18). UK services imports have expanded by around $40 \%$ since 2012 . France achieved a comparable services import growth, while services imports remained roughly constant in other major services economies such as Australia. The United Kingdom's growth rate is relatively similar to the OECD average, due to dynamic growth of services imports in several smaller OECD countries, including Ireland and the Netherlands. However, all other large OECD countries, such as Germany, the United States and Japan, exhibit lower growth rates of services imports.

Figure 18. Services imports growth in selected OECD countries, 2012=100, 2012-2019

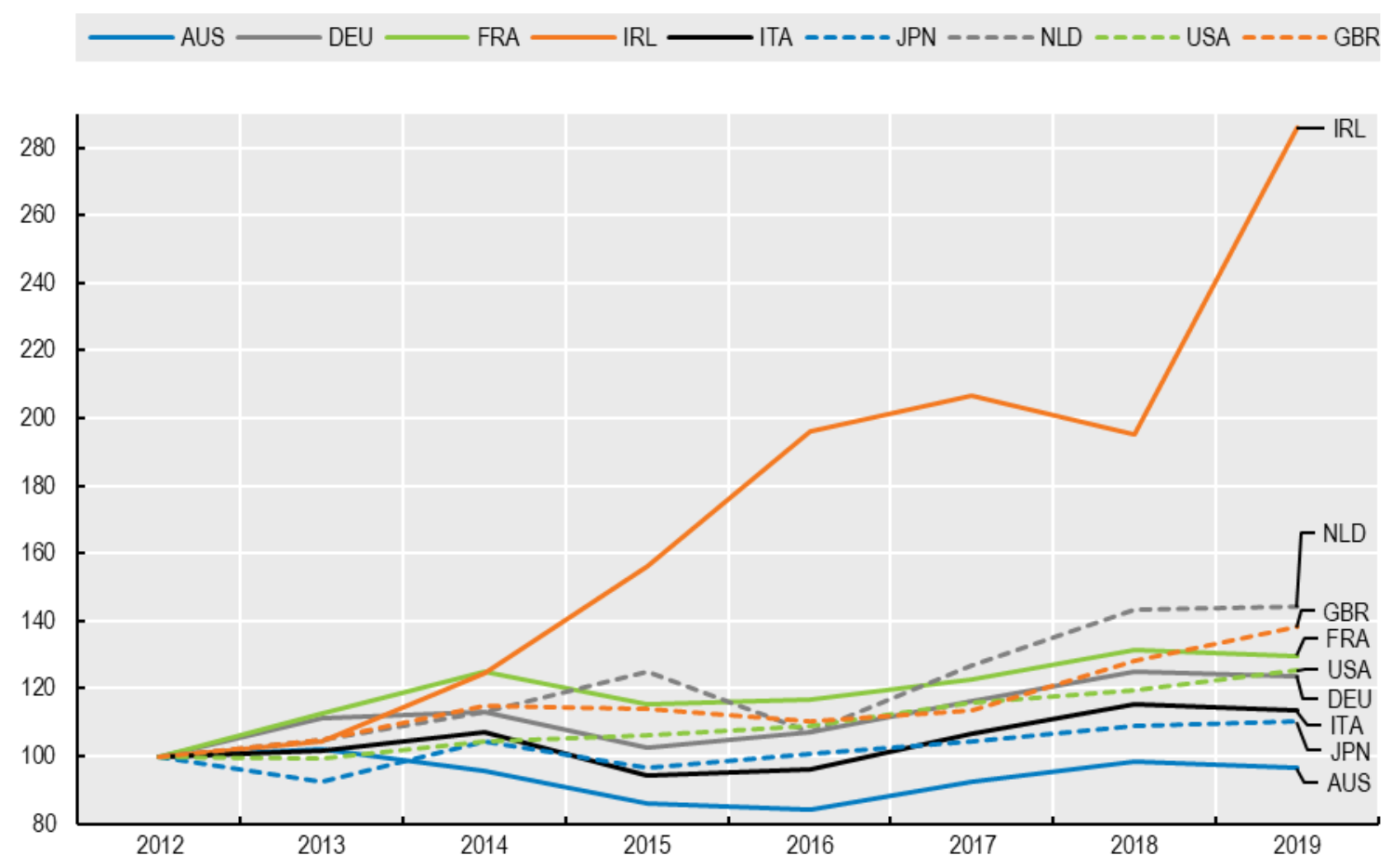

Source: OECD-WTO Balanced Trade in Services (BaTIS) data, reported values.

Imports of services outperformed goods imports in the United Kingdom by a wide margin. UK merchandise imports fell by around $2.5 \%$ between 2012 and 2019. OECD countries as a whole saw a small increase in goods imports by around $6 \%$ over the same period. Due to the important role of services as intermediate inputs, strong services import growth can help the manufacturing sector and other services sectors to become more competitive and export-oriented.

The dynamic of services trade shows that a strong position in services is crucial for global competitiveness in the years to come. Judging from past services trade performances, the United Kingdom seems to be well prepared for this challenge. However, this descriptive evidence on services trade growth may be misleading. Services exports in some countries may grow faster than in others due to their proximity to fast-growing markets or due to their specialisation in dynamic industries.

In order to isolate these factors, UK services export growth can be broken down into its main determinants using a shift-share decomposition. These determinants are the global demand for imported services, import demand for services from the United Kingdom's main trading partners, import demand for the services categories in which the United Kingdom has a strong export position, and a residual indicating export performance after accounting for the global, country-specific and sector-specific drivers of services export growth. Global demand for imported services is a major determinant of the United Kingdom's export 
performance (Figure 19). At the same time, services exports in the United Kingdom do not benefit from a favourable composition of trading partners. In other words, the United Kingdom primarily exports to countries where services imports grow at an average pace. The only exceptions are the years 2015 and 2016, when the geography of UK services exports helped the country to weather the downturn better than other economies.

UK services exports are concentrated in relatively fast-growing services sectors. Only in 2017 and 2018 there was a below-average growth in sectors in which the United Kingdom is a strong exporter In all other years, the United Kingdom benefitted from growing demand for its main services exports, such as financial services and business services.

Comparing these three main determinants of services exports with the United Kingdom's actual export growth, it becomes evident that the United Kingdom has underperformed in the recovery after the economic downturn in 2015. In 2016, services export growth was 3\% slower than what could be expected from its export patterns and global trends in services trade. The weak performance in 2016 might be related to the depreciation of the British Pound after the referendum on 23 June 2016. Export performance is calculated in US Dollars so that the depreciation has a direct negative impact on export growth. At the same time, the depreciation should have made UK exports more competitive, which might have compensated the demand effect. Figure 19 suggests that there was only a partial compensation. In 2017, the underperformance had narrowed to $1.5 \%$. In 2018, the United Kingdom managed to surpass its expected export growth for the first time since 2015. However, 2019 also ended with an underperformance of financial services exports, which grew only marginally, even though the three main determinants predicted an expansion of around $4 \%$.

Figure 19. Determinants of UK services export growth, 2013-2019

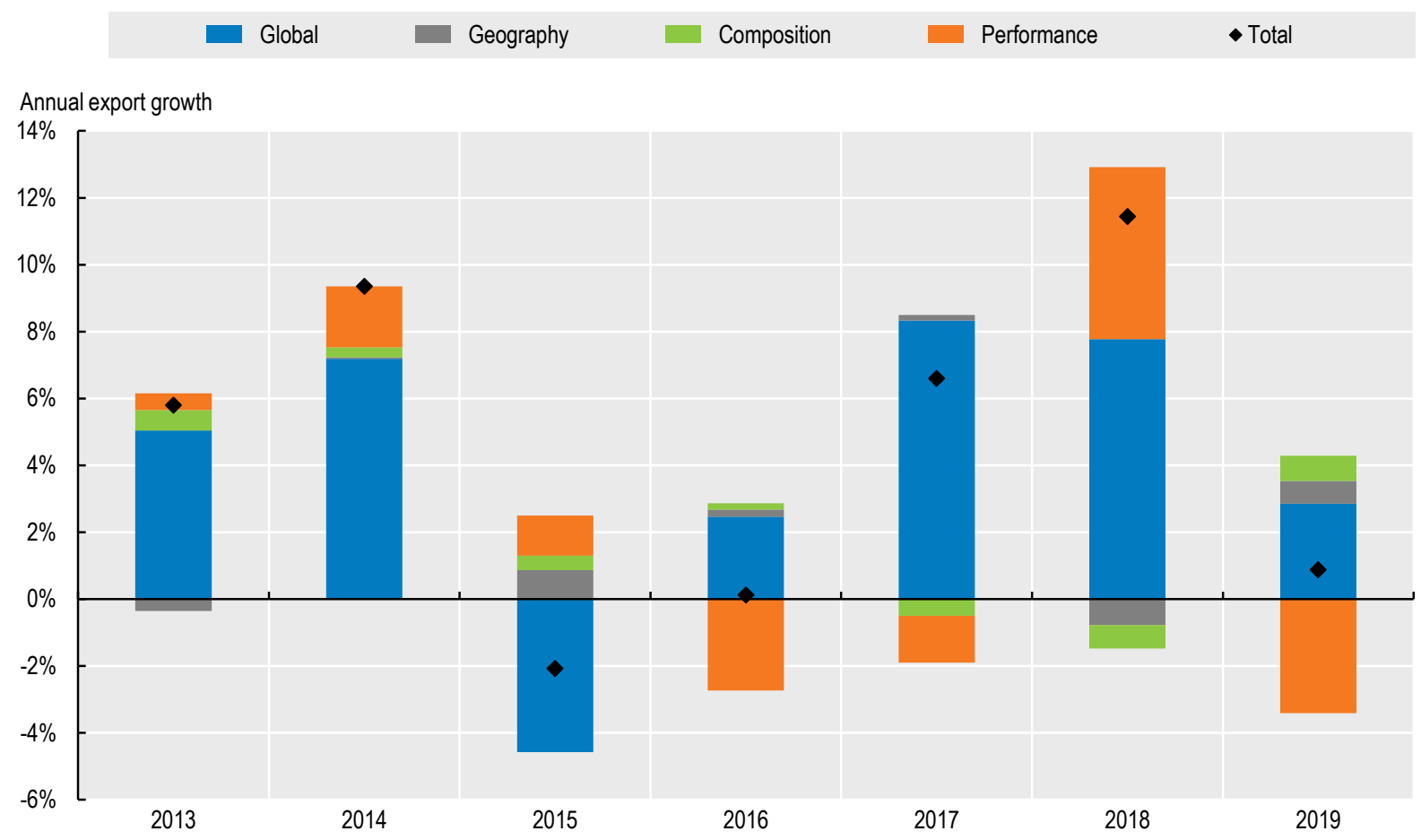

Note: "Global" is the average growth rate of global services imports, "Geography" is the weighted average services import growth of other countries with UK export shares as weights minus "Global", "Composition" is the weighted average of global sector-level services export growth with UK export composition as weights minus "Global", "Total" is observed UK services export growth, "Performance" is the difference between observed growth and the other three components.

Source: OECD-WTO Balanced Trade in Services (BaTIS) data. 


\section{Revealed comparative advantage and diversification of export markets and services types}

In comparison with other OECD countries, the United Kingdom is a strong exporter of insurance and pension services as well as financial services. The revealed comparative advantage (RCA) of the United Kingdom, a measure of export performance, is calculated by dividing a particular service's share in total exports of one country by the same service's share in total exports of a group of benchmark countries. Figure 20 uses total OECD services exports to the world as benchmark. A revealed comparative advantage larger than one indicates that a service is overrepresented in a country's export basket relative to that service's importance in total OECD services exports (Balassa, 1965).

The contribution of insurance and financial services to total services exports in the United Kingdom is more than twice as large as the contribution of this service in the average OECD country. In addition, the United Kingdom over performs in exports of personal, cultural and recreational services, as well as in exports of 'other business' services.

By contrast, exports in other services are of lower relevance in the United Kingdom than in other OECD countries. These services are transport services, travel services, construction, charges for the use of intellectual property, as well as telecommunications, computer and information services. The contribution of each of these five services to aggregate services exports in the United Kingdom is just slightly more than half of the OECD average.

Figure 20. Index of UK revealed comparative advantage, 2019

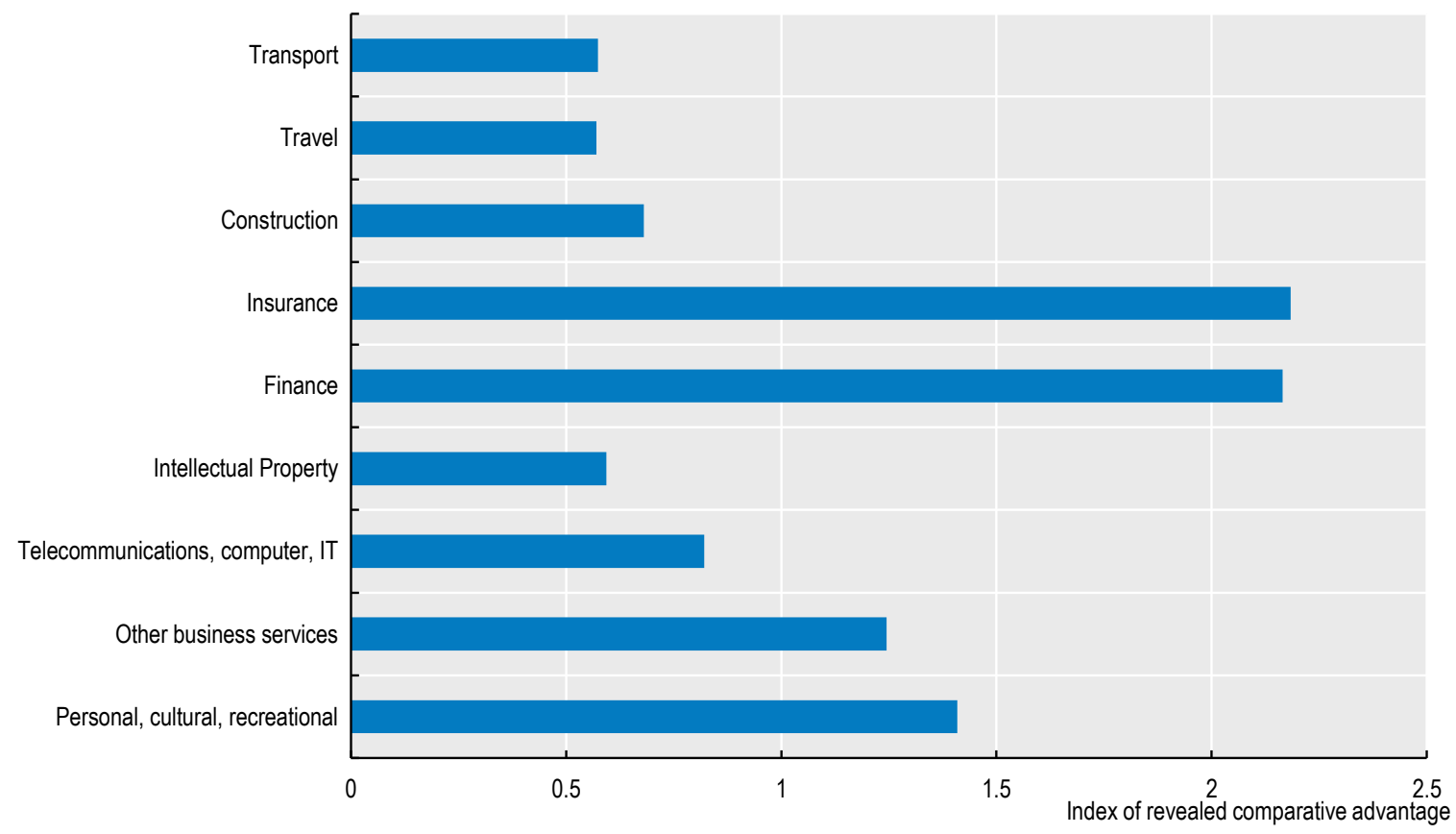

Note: RCA are calculated using OECD countries' services exports to the world.

Source: OECD-WTO Balanced Trade in Services (BaTIS) data, balanced values.

The strong UK performance in finance and insurance services also becomes clear in comparison with the RCAs of other major OECD countries (Figure 21). There is no other economy among the largest OECD members with a similarly strong position in these services. The United Kingdom also is among the top of the class in exports of 'other business' services, while exports of telecommunications, computer and IT services play an important role for Ireland, but also Germany and the Netherlands. 
The United Kingdom is not only more specialised in 'other business' services than other OECD countries, but growth of exports in 'other business' services accounted for roughly half of total UK services export growth between 2010 and 2019 (Figure 22). By contrast, other business' services only contributed one third to total services export growth in the OECD average. Other services contribute only relatively little to total services export growth in the United Kingdom. Growth in exports of travel services is roughly $12 \%$ of total growth, charges for the use of intellectual property account for $9 \%$ and transport services for $8 \%$. Exports of telecommunications and ICT services account for $7.5 \%$ of total UK services export growth. Export growth in telecommunications services is weaker in the United Kingdom compared to the OECD average. The United Kingdom also underperforms in export growth of financial services, mostly caused by a recent contraction between 2018 and 2019.

Figure 21. Index of revealed comparative advantage in selected OECD economies, 2019

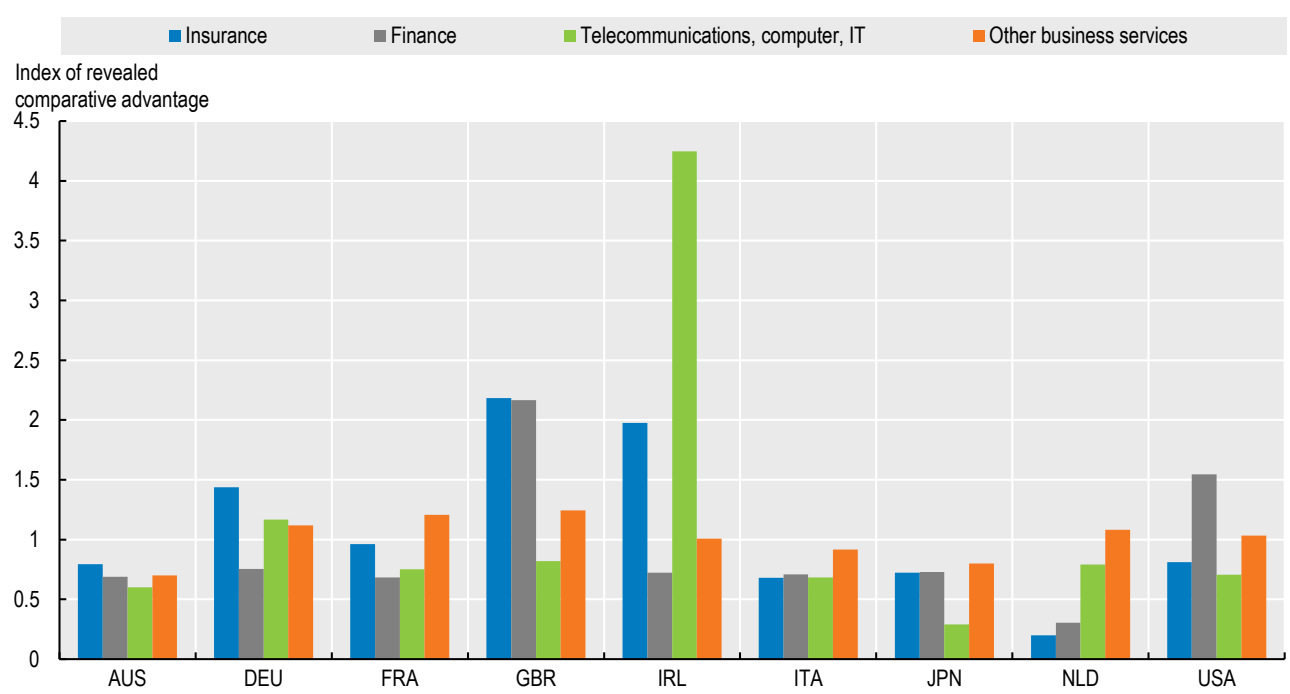

Source: OECD-WTO Balanced Trade in Services (BaTIS) data.

Figure 22. Drivers of services export growth, per cent contribution, UK vs OECD average, 2010 to 2019

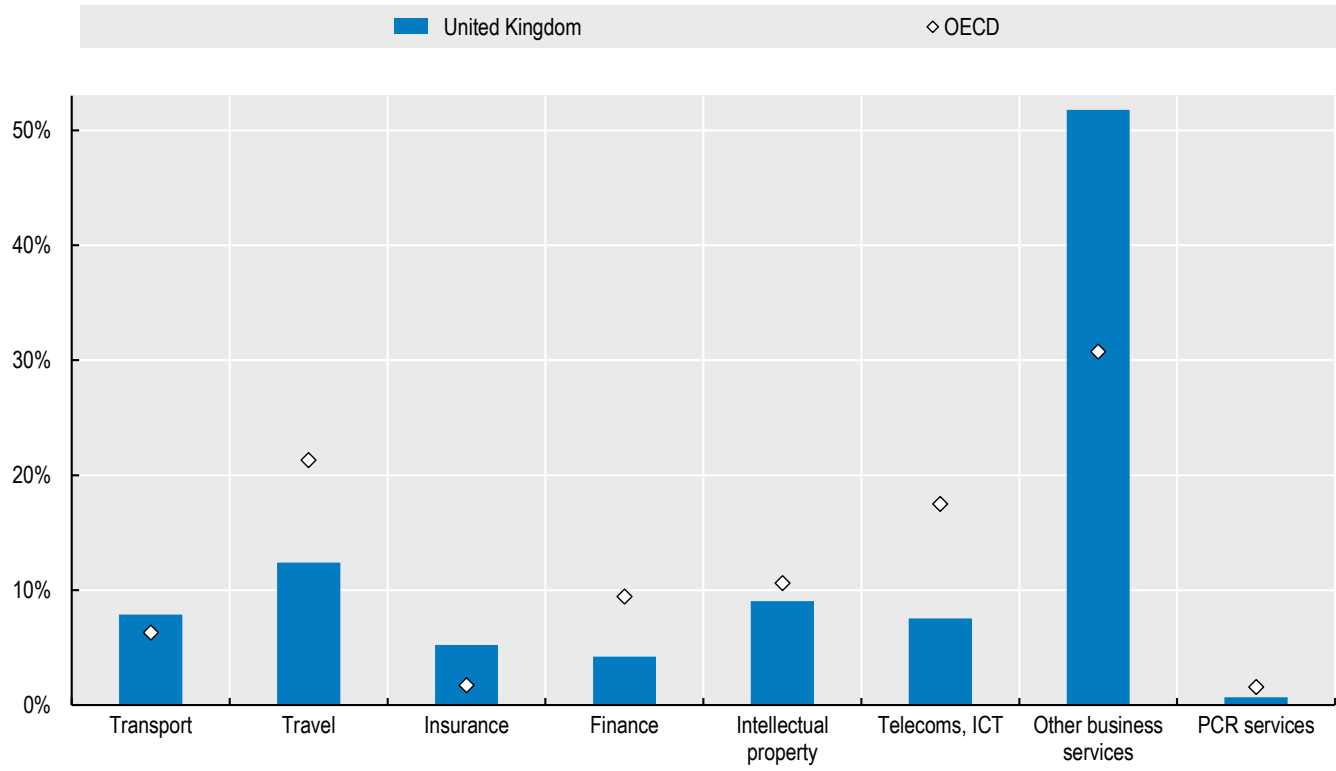

Source: OECD-WTO Balanced Trade in Services (BaTIS) data, reported values 
However, it has to be borne in mind that the analysis of revealed comparative advantage is descriptive, characterising patterns of services trade. It is not possible to draw policy conclusions directly from these numbers without considering further evidence. In particular, the revealed comparative advantage does not only indicate a strong performance in a specific service type but at the same time it shows a high degree of specialisation and dependence on a specific service. While this specialisation can bring economic benefits due to local spillovers and economies of scale (Eckert et al., 2019), it may also increase the vulnerability of an economy with respect to negative demand shocks or regulatory changes.

The United Kingdom's specialisation in key services has slightly increased over time. Based on the Herfindahl-Index, the concentration of UK services exports has increased between 2015 and 2018 from 1854 to 1957 (on a scale from 0 to 10 000). This development was mostly driven by strong export growth of 'other business' services already highlighted above. Exports of such services expanded by around $35 \%$ in just three years, further widening the gap to financial services, the UK's second most important services export (Figure 23). With the exception of personal, cultural and recreational services, no other services category experienced comparable growth in the same period. Exports in all other services expanded by between $10 \%$ and $20 \%$ during this time.

Figure 23. UK services export growth by sector and initial export value, 2015-2019

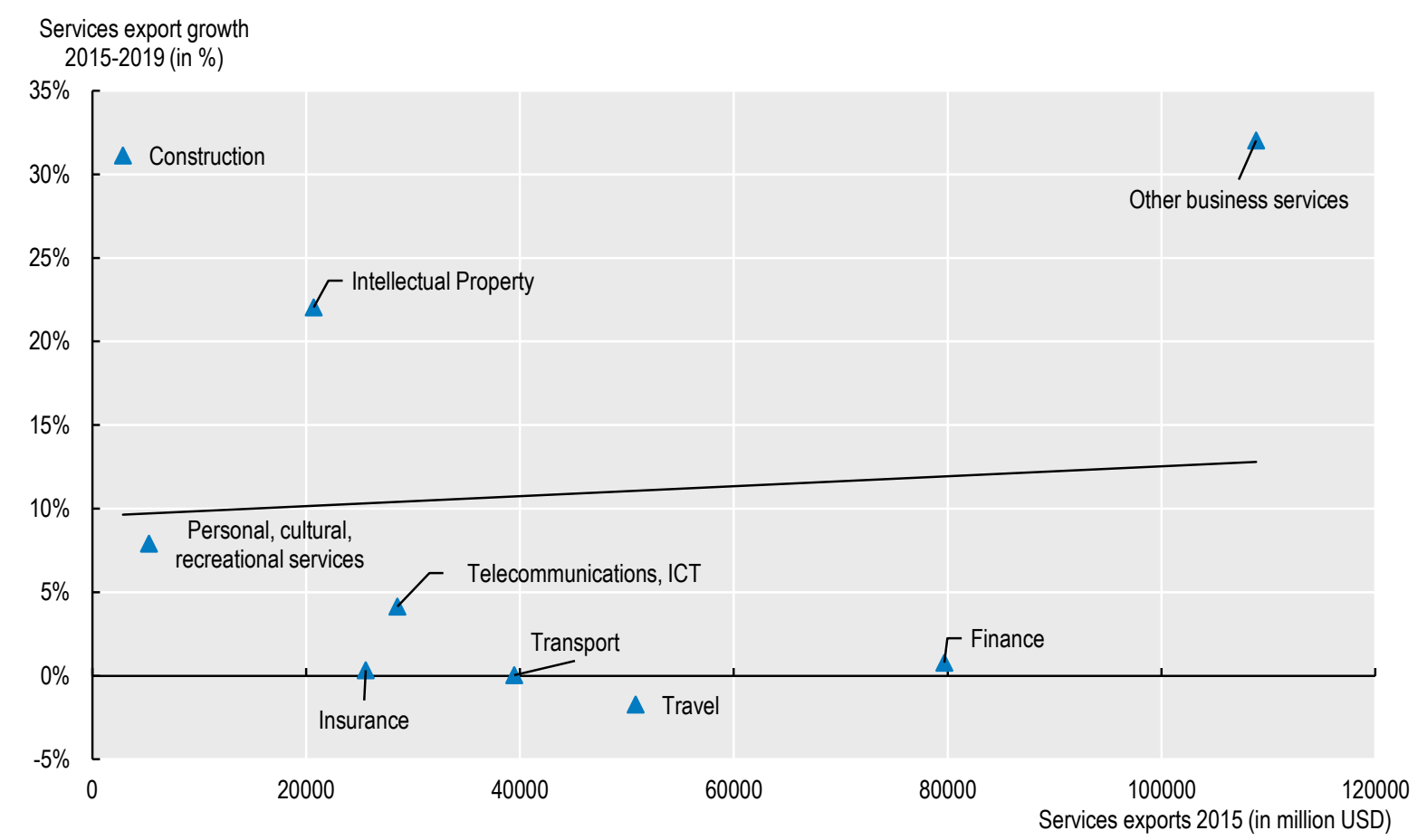

Source: OECD-WTO Balanced Trade in Services (BaTIS) data, reported values.

At the same time, the United Kingdom managed to raise diversification of export markets. Between 2015 and 2018, services growth was over-proportionally targeted towards markets with relatively lower imports from the United Kingdom in 2015. This can easily be seen by the negative trend line in Figure 24. The United Kingdom achieved high growth rates of more than $60 \%$ in exports to markets of intermediate importance, such as Nigeria, Romania, Austria and Malaysia. By contrast, exports to the most important markets such as the United States, Germany, France and the Netherlands only expanded by less than $30 \%$. 
Figure 24. UK services export growth by market and initial export value, 2015-2019

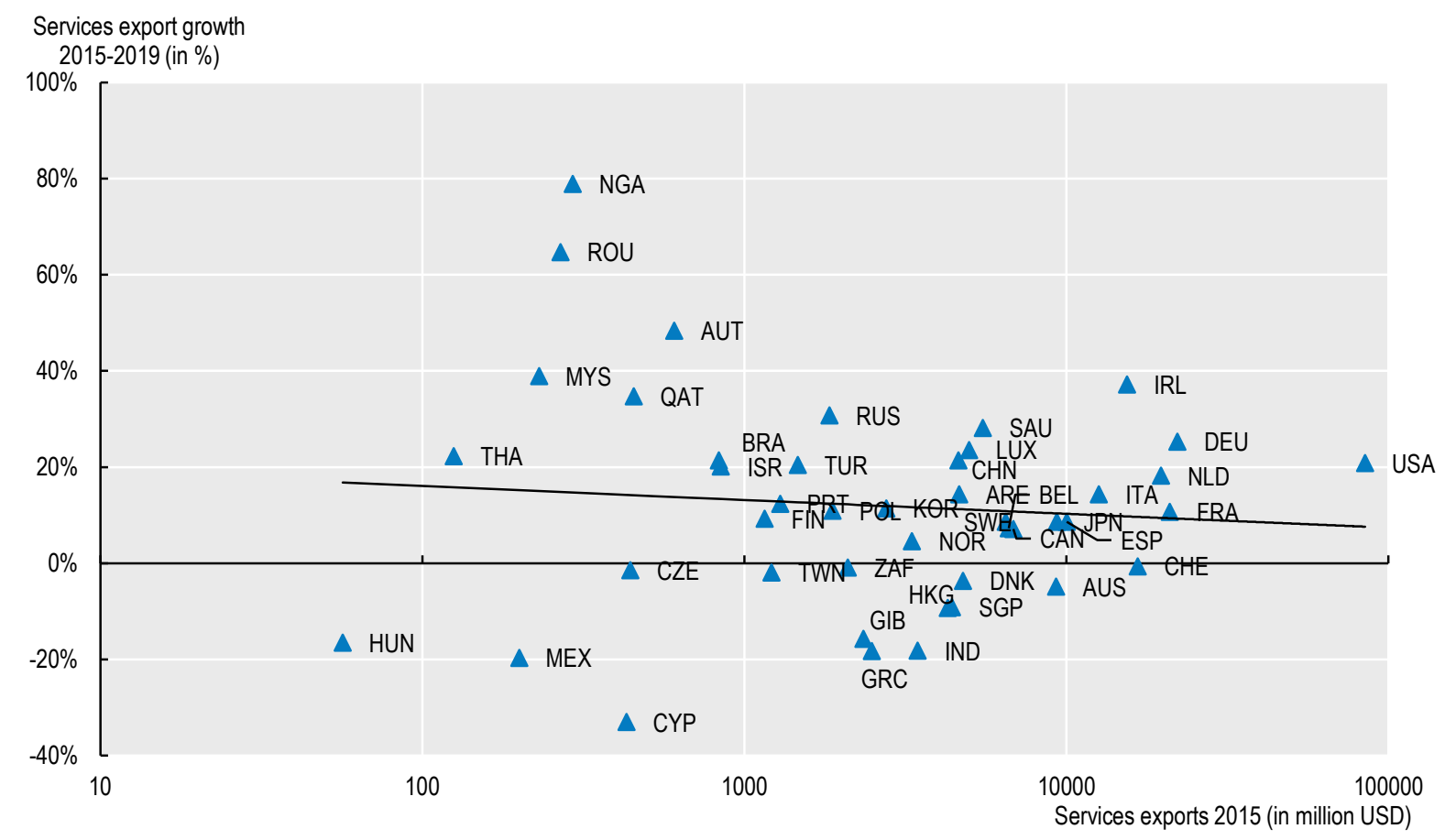

Source: OECD-WTO Balanced Trade in Services (BaTIS) data, reported values.

This pattern is similar to those of other developed economies such as France, Germany, Japan and the United States. Ireland achieved impressive services export growth of $64 \%$ over 2015-2019 with its second largest trading partner for services, the United States. Australian services exports to its most important trading partner China grew faster than exports to any other country.

\section{The role of SMEs for services trade}

An important share of cross-border services exports comes from small and medium sized enterprises (SMEs). SMEs accounted for roughly $20 \%$ of UK services exports and between $12 \%$ and $14 \%$ of UK services imports in 2018 (Figure 25). These features are broadly similar to what can be observed in other European countries, where trade in services is dominated by large enterprises ( 250 or more employees) or enterprises with less than 250 employees (Eurostat, 2019). Smaller enterprises play an important role only in few small countries (Luxembourg, Estonia).

Regulatory restrictions to services trade disproportionately discourage smaller firms and newer firms without export experience from competing in a market (Benz, Rouzet and Spinelli, 2020). These results suggest that barriers to trade in services entrench the market shares not only of domestic firms, but even of large incumbent exporters. Evidence also suggests that smaller firms benefit more from improvements in the overall trade facilitation environment relative to large firms (López González and Sorescu, 2019).

The contribution of SMEs to cross-border services exports differs across sectors. Firms with less than 250 employees are particularly important for exports of other professional, scientific and technical activities, where more than $70 \%$ of UK services exports come from SMEs (Figure 26). Also exports of other professional services, such as activities of head offices, management consultancy activities, employment activities and advertising and market research are dominated by SMEs. The importance of SMEs is smallest for the repair and installation of machinery and equipment and scientific research and development, where they account for less than $20 \%$ of UK services exports. 
Figure 25. Contribution of SMEs to UK services trade in 2018

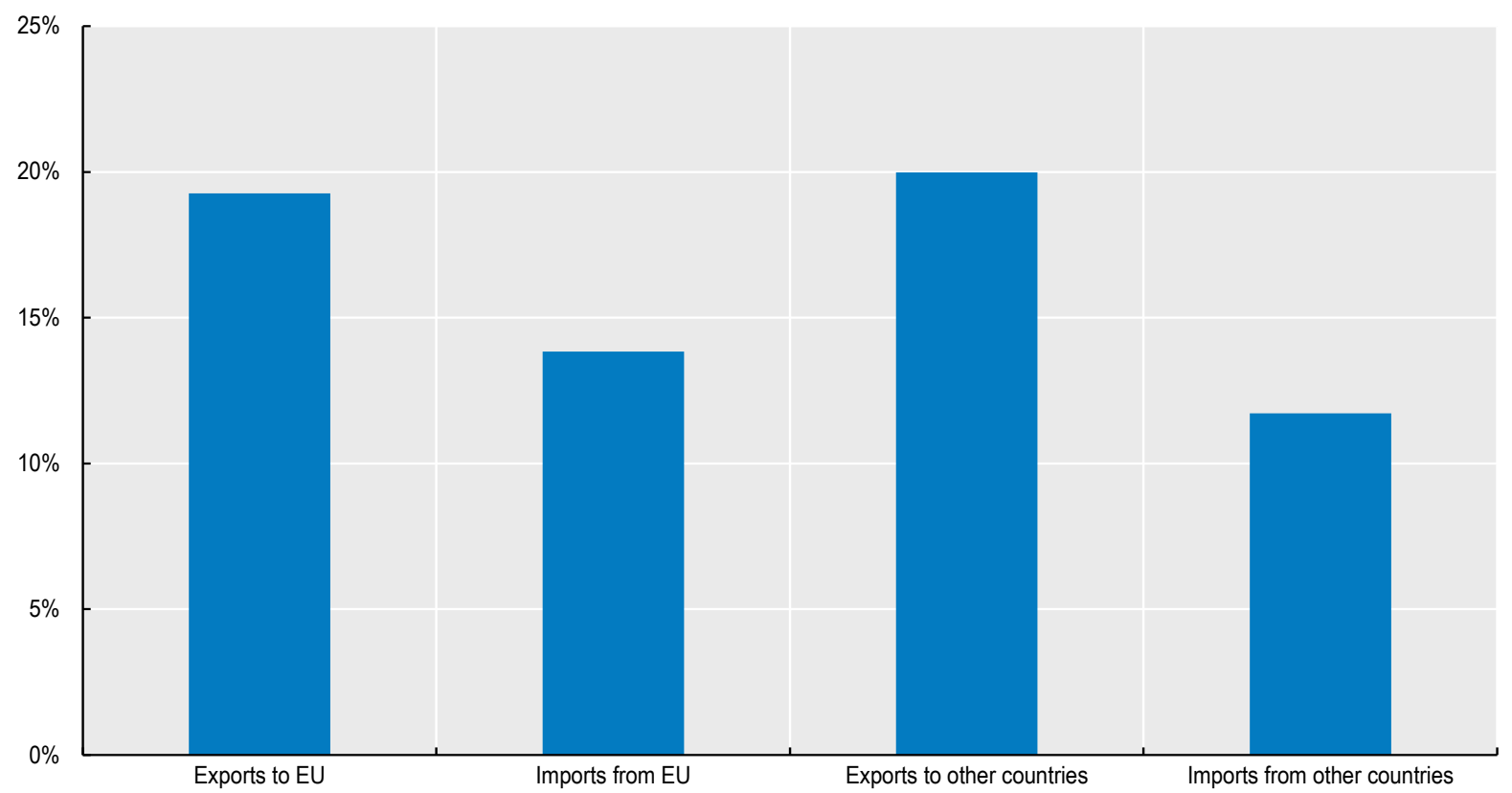

Source: ONS UK trade in services by business characteristics, 2016-2018.

Figure 26. Contribution of SMEs to UK services trade by sector, 2018

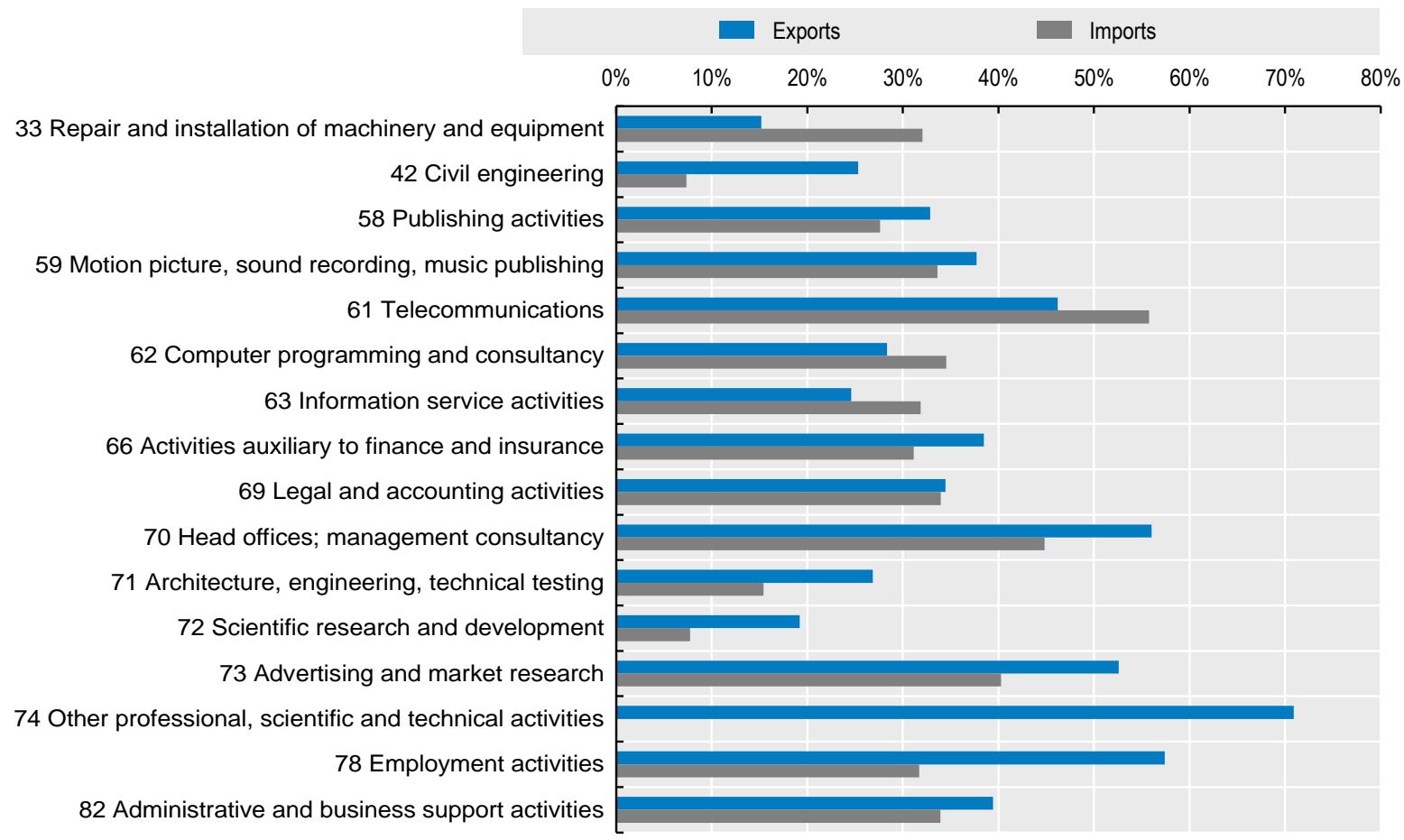

Source: ONS UK trade in services by business characteristics, 2016-2018. 


\section{Large foreign-owned firms account for a large share of UK services trade}

Experimental data from the ONS indicate that large foreign-owned businesses, which have 250 or more employees, were the largest driver of UK trade in services in 2018 (Figure 27). Those firms traded more in services than any other business type. However, small domestically-owned businesses traded more than small foreign-owned businesses. In sectors such as information services activities, foreign-owned firms account for more than $80 \%$ of total services trade. Also exports of scientific research and development services, advertising and market research services, real estate services, motion picture, video and television programme services, publishing services, architectural and engineering services, and services auxiliary to financial services and insurance are dominated by foreign-owned firms (Figure 28).

Figure 27. Contribution to total trade in services by firm ownership and size, 2018

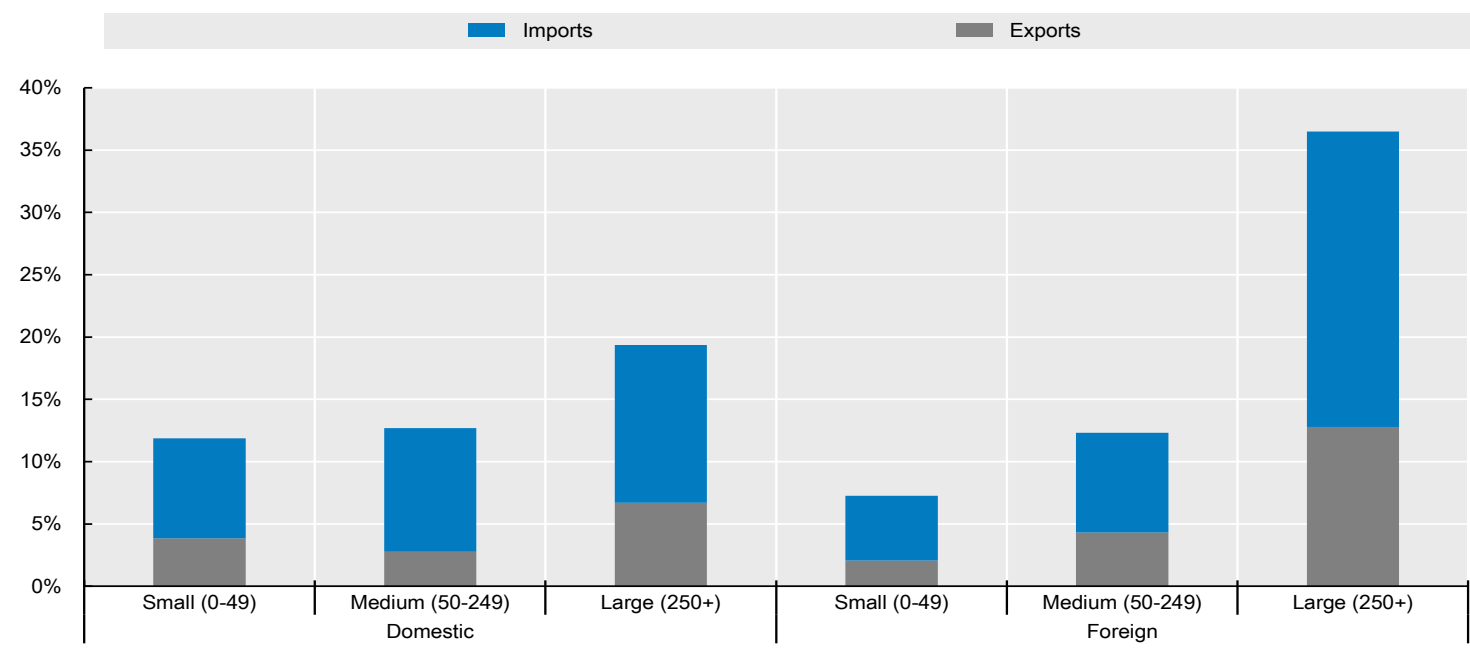

Source: ONS UK trade in services by business characteristics, 2016-2018.

Figure 28. Contribution of foreign-owned firms to UK services trade by sector, 2018

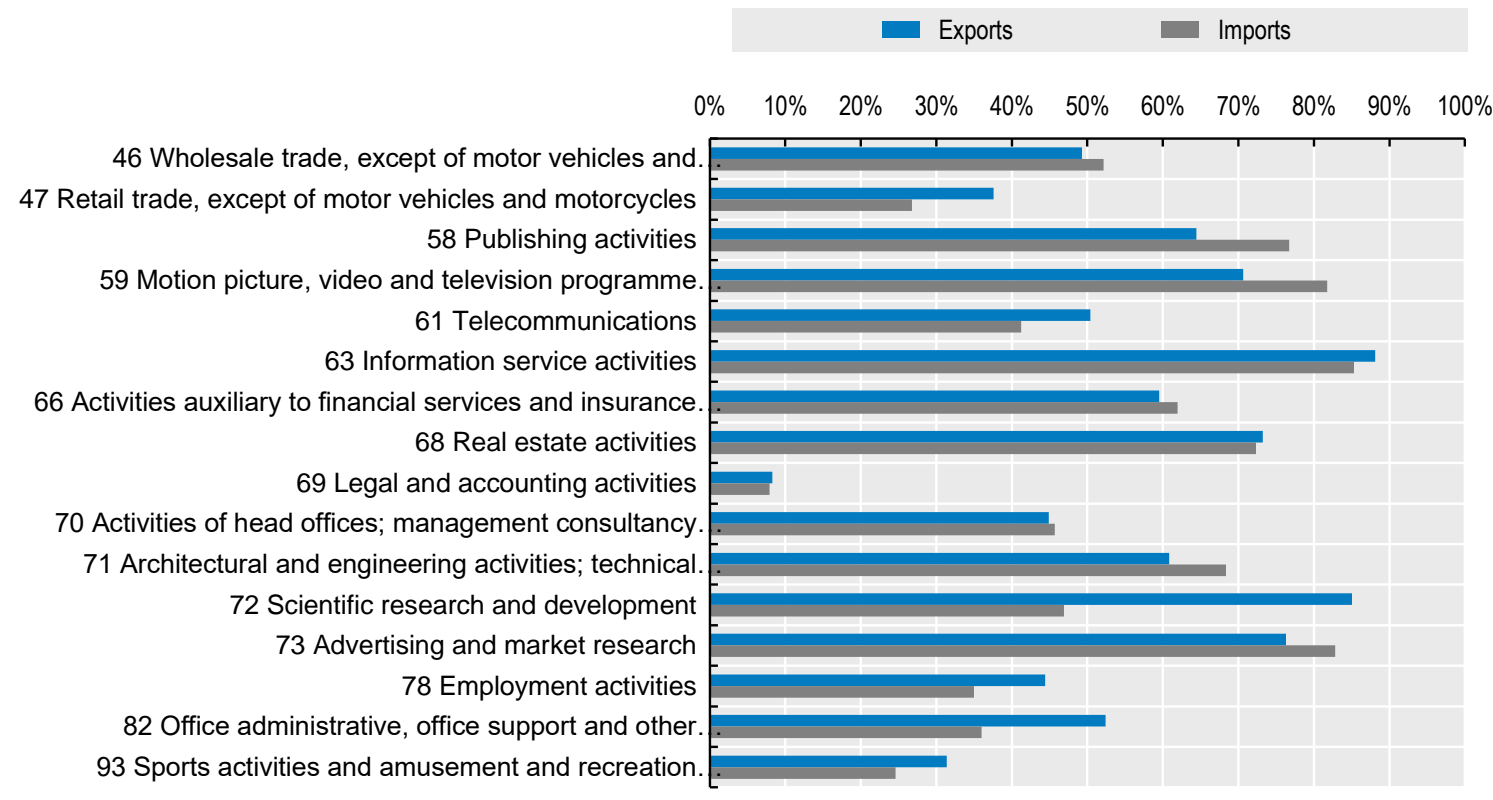

Source: ONS UK trade in services by business characteristics, 2016-2018. 


\section{UK services depend heavily on final demand from the European Union}

It is possible to use OECD Trade in Value Added data to quantify the dependence of UK output on foreign final demand. This can be measured by the additional UK output in USD, resulting from an increase of foreign final demand by USD 1000. Obviously, a large share of foreign final demand will be met by local output in those countries. The small share satisfied by foreign output is split between all countries. Hence, the resulting effect in the United Kingdom is fairly small. Nonetheless, the comparison of different final demand shocks provides interesting insights into the relevance of the different foreign markets for UK output.

For this purpose, Figure 29 indicates additional UK output resulting from an additional USD 1000 of final demand in the European Union, the United States and China. UK dependence on final demand from the European Union is fairly large. Additional final demand of USD 1000 in the European Union creates demand for output from the United Kingdom by around USD 1.5. Less than $10 \%$ of this will be output in the UK manufacturing sector. The vast majority comes from services, dominated by real estate services, 'other business' services, and wholesale and retail distribution services.

UK dependence on other markets is substantially smaller. Final demand of USD 1000 in the United States and China will only raise UK output by USD 0.1 and USD 0.6, respectively. Again, the majority of this additional output will come from services sectors. This analysis shows the high importance of EU final demand for UK services and the dependence of firms in these sectors on the EU market.

Figure 29. UK value added in USD 1000 of final demand in major economies

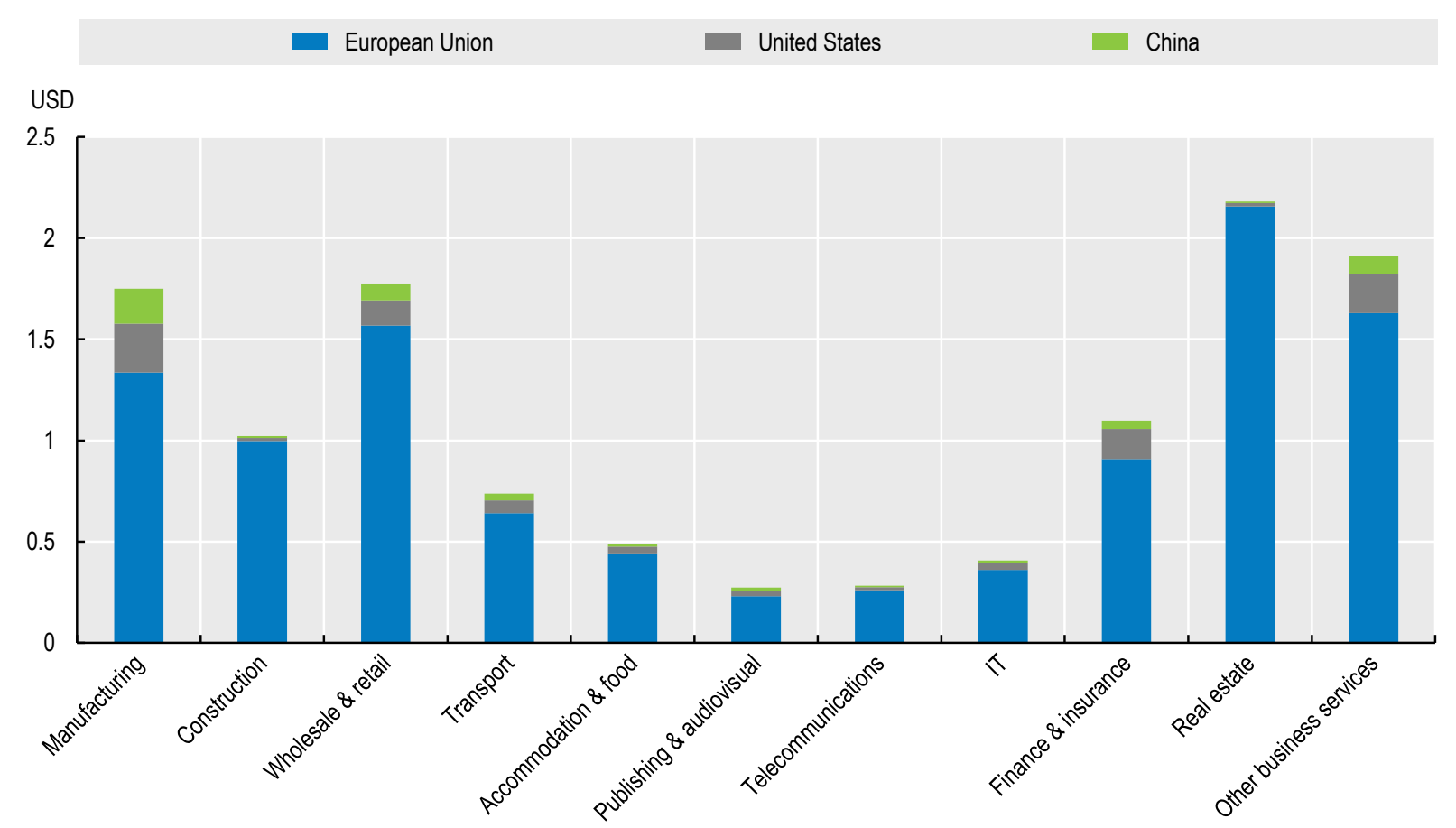

Note: The analysis is based on data for 2015 .

Source: OECD TiVA database. 


\section{Growth of services productivity has slowed}

Patterns of services trade are closely linked to underlying trends in services productivity. The following analysis of services productivity relies on a decomposition of value added growth into a number of explanatory factors. These factors are the number of hours worked, the composition of the workforce, the stock of ICT and non-ICT capital and the stock of intangible capital. Changes in value added that cannot be explained by changes in these factors are residually attributed to total factor productivity (TFP).

Services value added in the United Kingdom grew in almost all years since 1996 (Figure 30). Only exception is 2009 , the year of the global financial crisis, with a contraction of around $6 \%$. In addition, TFP growth accounts for roughly half of total growth in services value added between 1996 and 2016. However, growth of TFP has slowed since 2011 compared to the pre-crisis period. While productivity used to be the largest component of total value added growth in the United Kingdom before 2008, services value added is mostly driven by growth in the number of hours worked in the post-crisis period. In 2016 TFP growth even turned negative for the first time since 2009.

Figure 30. Decomposition of UK total factor productivity growth in services, 1996-2016

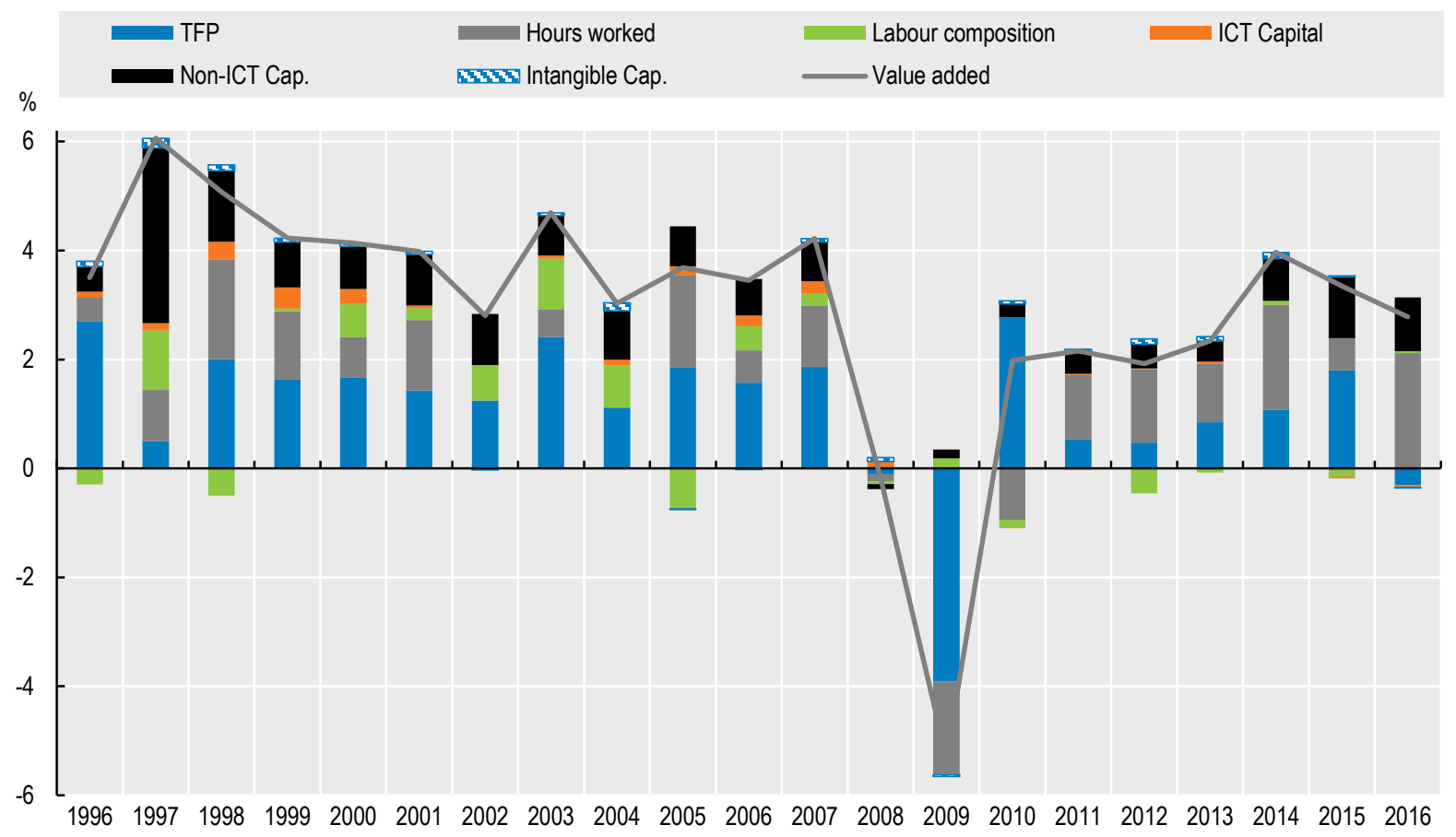

Source: EU KLEMS database.

UK productivity growth after the financial crisis was particularly weak compared to the patterns observed in previous business cycles and to developments in peer countries (OECD, 2020). In the five years from 2011 to 2016, UK services TFP growth averaged $0.7 \%$ annually. This is less than half of its pre--financial crisis rates. In comparison, many other OECD countries managed to return to their post-financial crisis growth rates. In Germany, the Netherlands and the United States, TFP growth in services is roughly identical to trend growth before 2008. Japan even managed to escape from negative growth rates and catch up to the other large OECD economies (Figure 31). With respect to productivity levels, in 2016 GDP per hour worked in the United Kingdom was $17.8 \%$ lower than in the United States and also low compared to France and Germany (OECD, 2020). 
Figure 31. Total factor productivity growth in services pre- and post-global financial crisis, selected economies

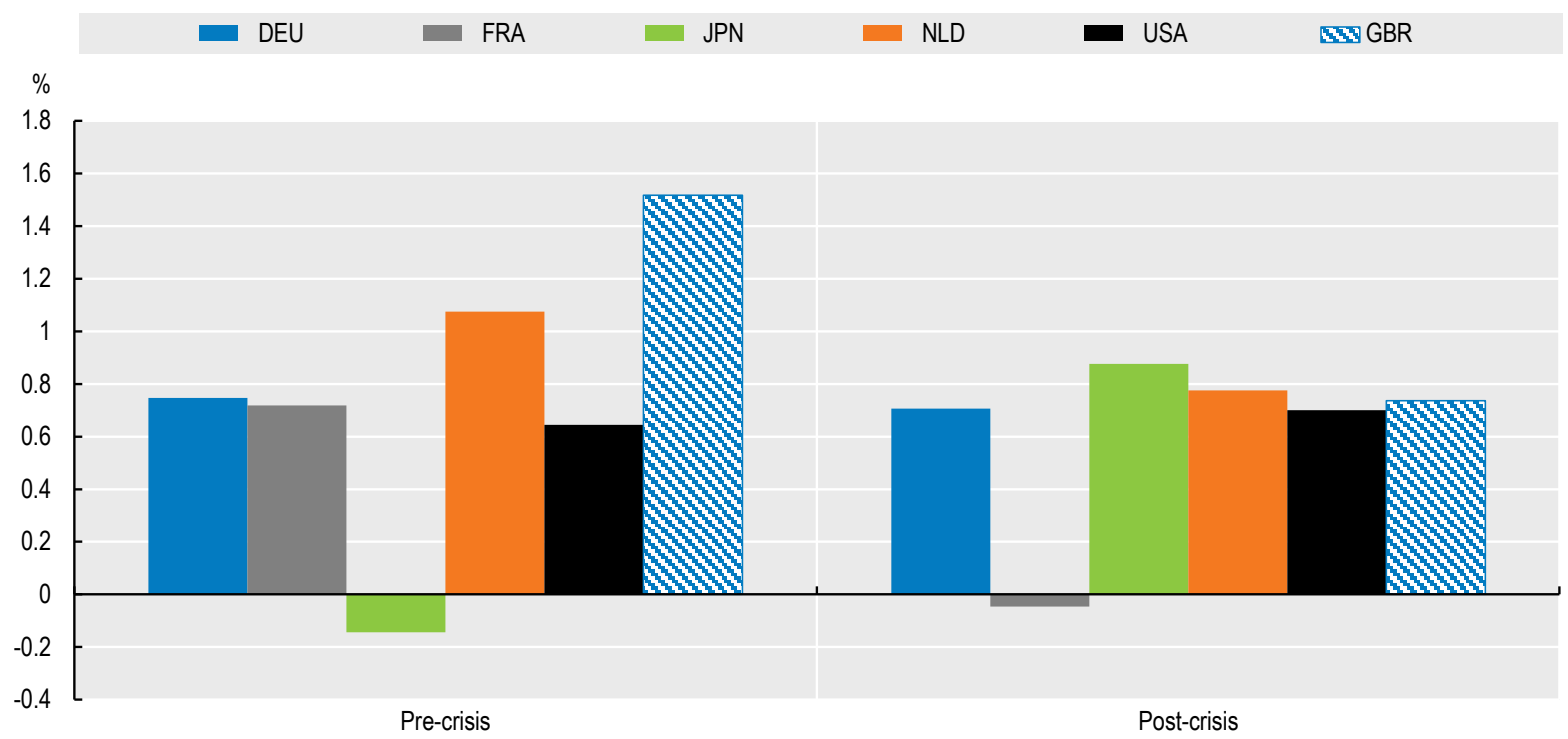

Note: Average total factor productivity growth in services in the period prior to the global financial crisis (1997-2008) and during the recovery after the crisis (2011-2016).

Source: EU KLEMS database.

There are considerable differences across sectors during these recent years of sluggish productivity growth in services (Figure 32). Productivity growth in this period was most dynamic in the publishing, broadcasting and audiovisual services sector, with an annual TFP growth of more than $3 \%$. Also, wholesale and retail trade, IT and other information services, real estate, and professional, scientific, technical, administrative and support service activities experienced positive TFP growth over this period that was larger than productivity growth in the manufacturing sector. Value added of IT services and professional services was also boosted by an increase in the number of hours worked in the sector. This suggests that productivity growth often coincides with the creation of additional services jobs.

By contrast, productivity growth was particularly weak in finance, accommodation and food services, telecommunications and transport (Figure 32). All sectors experienced a drop in TFP between 2011 and 2016. In finance and telecommunications services, declining productivity coincides with virtually zero employment growth. By contrast, additional employment was created in the accommodation and food sector and in transport services. Sluggish productivity growth in these services sectors plays an important role for the United Kingdom's overall weak productivity performance. This is particularly true for financial services, which used to be a main driver of productivity growth before the global financial crisis (Tenreyro, 2018; Riley et al., 2018).

More recent data from the ONS highlight the diverging trends in total factor productivity growth across services sectors (Figure 33). Cumulative TFP growth between 2011 and 2019 stands at around 20\% in the wholesale and retail trade sector and around $15 \%$ for information and communication services. Also, professional services experienced positive TFP growth. By contrast, transport services and finance are two services sectors with negative TFP growth over this period. TFP growth in the manufacturing sector was also negative between 2011 and 2019. 
Figure 32. Decomposition of UK TFP growth in services, by sector, average 2011-2016

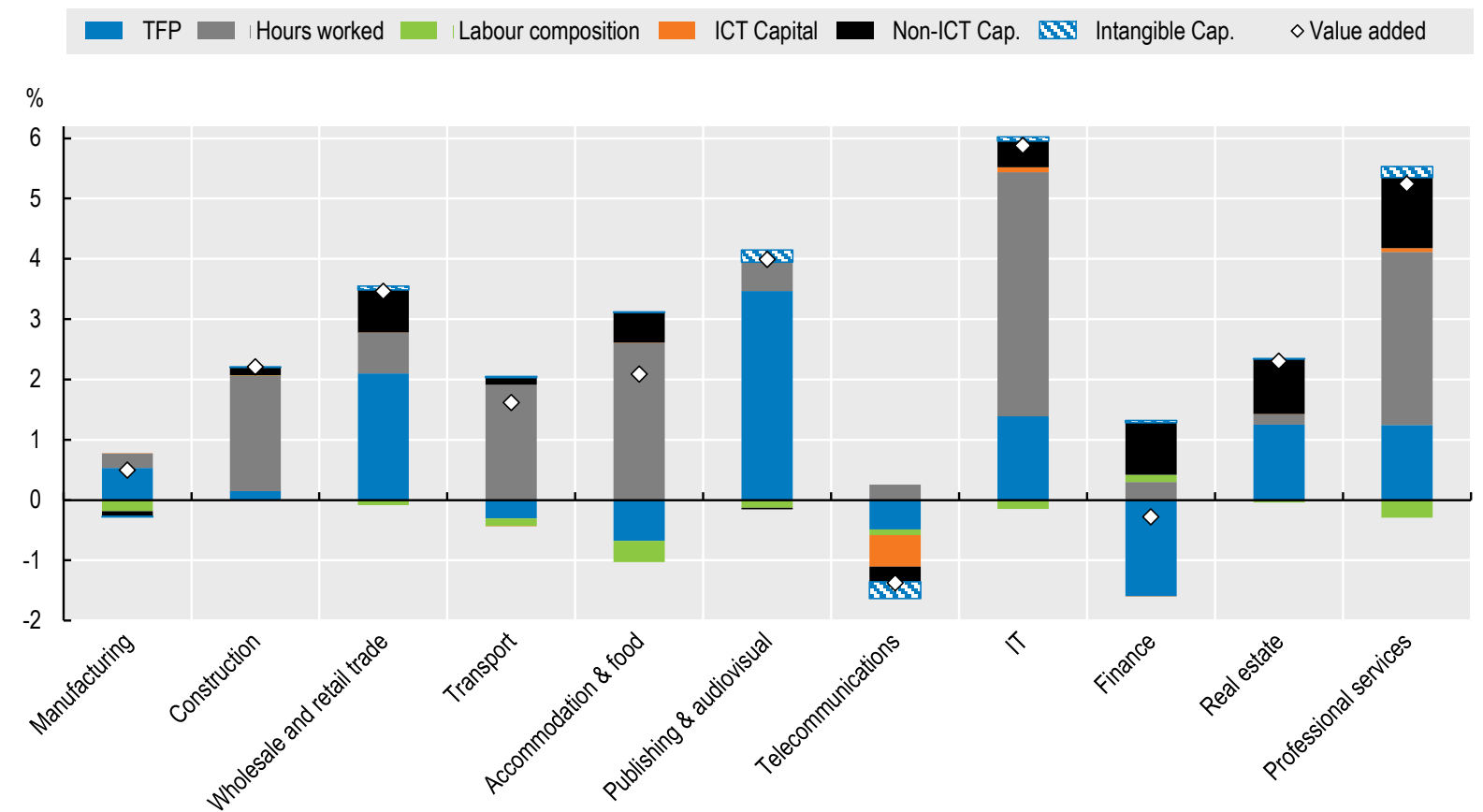

Note: Value added growth decomposition by sector, average 2011-2016.

Source: EU KLEMS database.

Figure 33. UK TFP growth by sector, 2011-2019

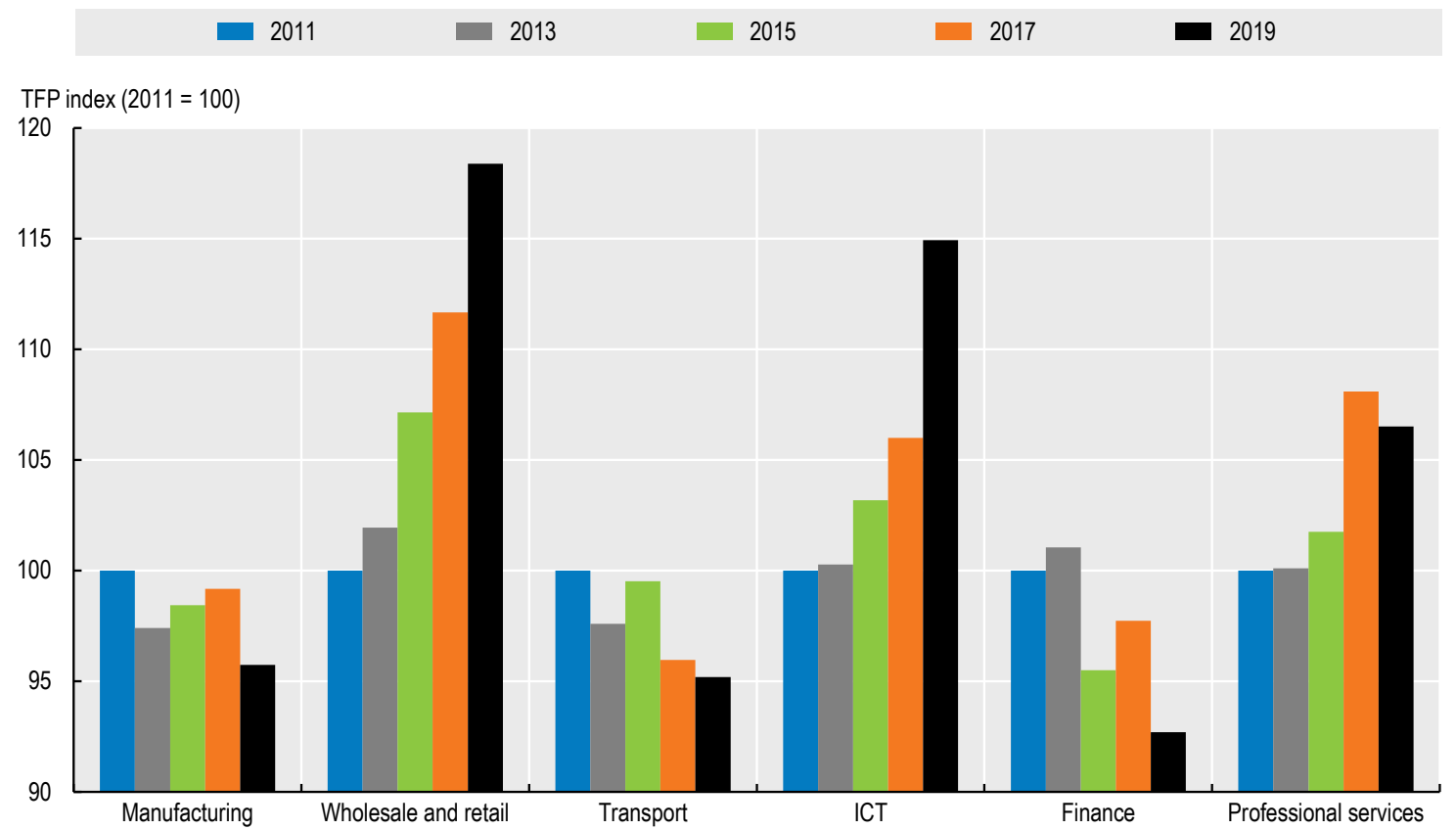

Source: ONS Multi-factor productivity estimates. 
Low investment rates exacerbate the problem of sluggish TFP growth. Even in the absence of growth in total factor productivity, capital deepening would raise labour productivity and could lead to higher wages for workers. However, the contribution of capital accumulation to value added growth is marginal in most sectors. This is particularly true for ICT capital and intangible capital, while non-ICT capital (such as machinery and non-residential buildings) can slightly support value added growth in a couple of sectors.

The productivity shortfall in services is also partly caused by low innovation rates and a lack of digital and management skills (OECD, 2020; Barnett et al, 2014). In addition, there is evidence that the slowdown is due to the reallocations of workers across firms. In particular at the top of the productivity distribution, workers do not reallocate to the most productive firms as fast as they used to do before the global financial crisis (Schneider, 2018). Idiosyncratic shocks to large firms also seem to explain part of the slowdown (Dacic and Meloninna, 2019). ${ }^{4}$

\section{There is evidence that services trade is beneficial to job creation and wages, notably in the United Kingdom}

According to the OECD trade in employment (TiM) database, $20.8 \%$ of total UK employment is supported by exports of goods and services. The share of jobs relying on foreign final demand in the United Kingdom is even larger for services due to the importance of direct services imports and services embodied in exports of manufactured goods. $28.2 \%$ of all business services jobs (ISIC rev. 4 division $45-82$ ) and $33.7 \%$ of all jobs related to information, finance, real estate and other business services (ISIC rev. 4 division 5882) are supported by final demand from abroad.

Recent evidence suggests that the rise in services trade has translated into increased labour-market performance, both in terms of employment and wages in the United Kingdom and in other advanced economies. Relying on firm-level data for a heterogeneous sample of countries, Lassmann (2020) concludes that importing, offshoring and exporting activities are generally associated positively with firm employment in advanced economies. In addition, firm's overall wage responses are on average positive and quantitatively small. Examination of individual wages within the same job points to a positive relationship between exports and imports and wage on average across workers.

Empirical analyses on the United Kingdom are consistent with these results and allow for a more precise quantification. Lassmann and Spinelli (2020) estimate that the $76 \%$ increase in services imports in the United Kingdom between 2012 and 2017 has translated into a rise in employment of between $2.4 \%$ and $11.7 \%$. The rise in offshoring by $5 \%$ would explain an employment growth of $1.7 \%$ to $3.4 \%$, and the increase in services exports by $56 \%$ would imply a $3 \%$ rise in employment.

Turning to the impact on wages, worker-level analysis suggests a positive causal relationship between trade in services and hourly wages. However, the positive effect of services trade is distributed differently across firms and individuals. Increases in services imports have a moderately beneficial effect on the wages of female workers and contribute to mitigating existing gender inequalities. In contrast, wages are negatively associated with higher services trade barriers in the markets in which UK firms trade. Finally, the evidence is ambiguous regarding the link between enhanced services trade activity and skills. Evidence of a skill bias in wages related to increased services exports and imports at the international level is mixed (OECD, 2020). The observed bias towards mid-skilled workers in an emerging economy and towards highskilled ones in OECD countries is in line with the aggregate skill structure of services observed across countries.

\footnotetext{
${ }^{4}$ For a more extensive discussion on the reasons for slow productivity growth in the UK economy, see OECD (2020).
} 


\section{Vulnerability of services workers amid COVID-19}

The economic and social impact of the global spread of the COVID-19 pandemic is not shared equally across different sectors. Sectors are impacted differently by social distancing rules and economic lockdown implemented in the United Kingdom and other countries. Sectors that were forced to limit or even stop their operations, such as hotels and restaurants, physical retail, construction, or air transport experienced the most severe downturn. Figure 34 shows the most dramatic reduction in the number of hours worked in the accommodation and food services sector, followed by other services (e.g. arts, entertainment, recreation, personal services) construction, as well as wholesale and retail trade.

The decline in working hours was most dramatic in the second quarter of 2020. For example, employees in the accommodation and food services sector were able to work only half as much as in the second quarter of 2019. Working hours rebounded slightly in the third quarter but were still substantially below their 2019 levels in all sectors.

Figure 34. Change in UK hours worked by sector, Q1 2020 - Q3 2020

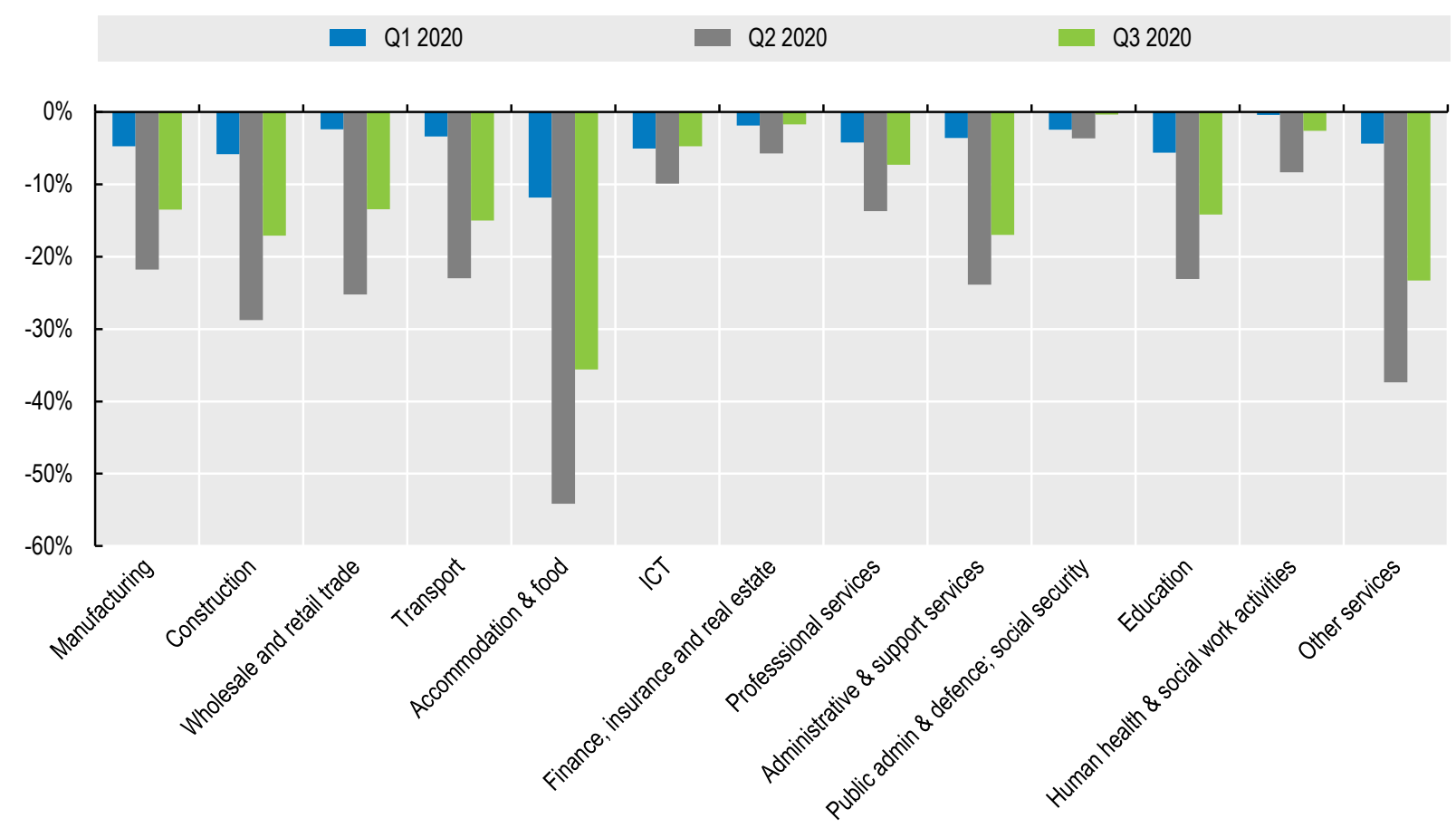

Note: Percentage change in average actual weekly hours worked by industry relative to previous year, United Kingdom.

Source: ONS Labour Force Survey.

The economic impact of the COVID-19 pandemic can be alleviated when workers are able to work remotely. Working from home does not only help to sustain operations in the presence of social distancing rules that could impact the ability of workers to be present at their regular workplace, it also protects workers from the risk of infection on public transport or at the workplace.

The EU Labour Force Survey for the United Kingdom shows that in 2018 around 24\% of workers in the United Kingdom work from home at least sometimes (Figure 35). In other words, three-quarters of the workforce did not work from home prior to the COVID-19 pandemic, either due to personal preferences, 
because they did not have the option of working from home, or a combination of these factors. ${ }^{5}$ While teleworking was introduced for additional workers during the COVID-19 pandemic, ${ }^{6}$ numbers on structural teleworking prior to the pandemic expose the ex ante vulnerability of different workers.

\section{Figure 35. UK working from home patterns, by sector and gender, 2018}

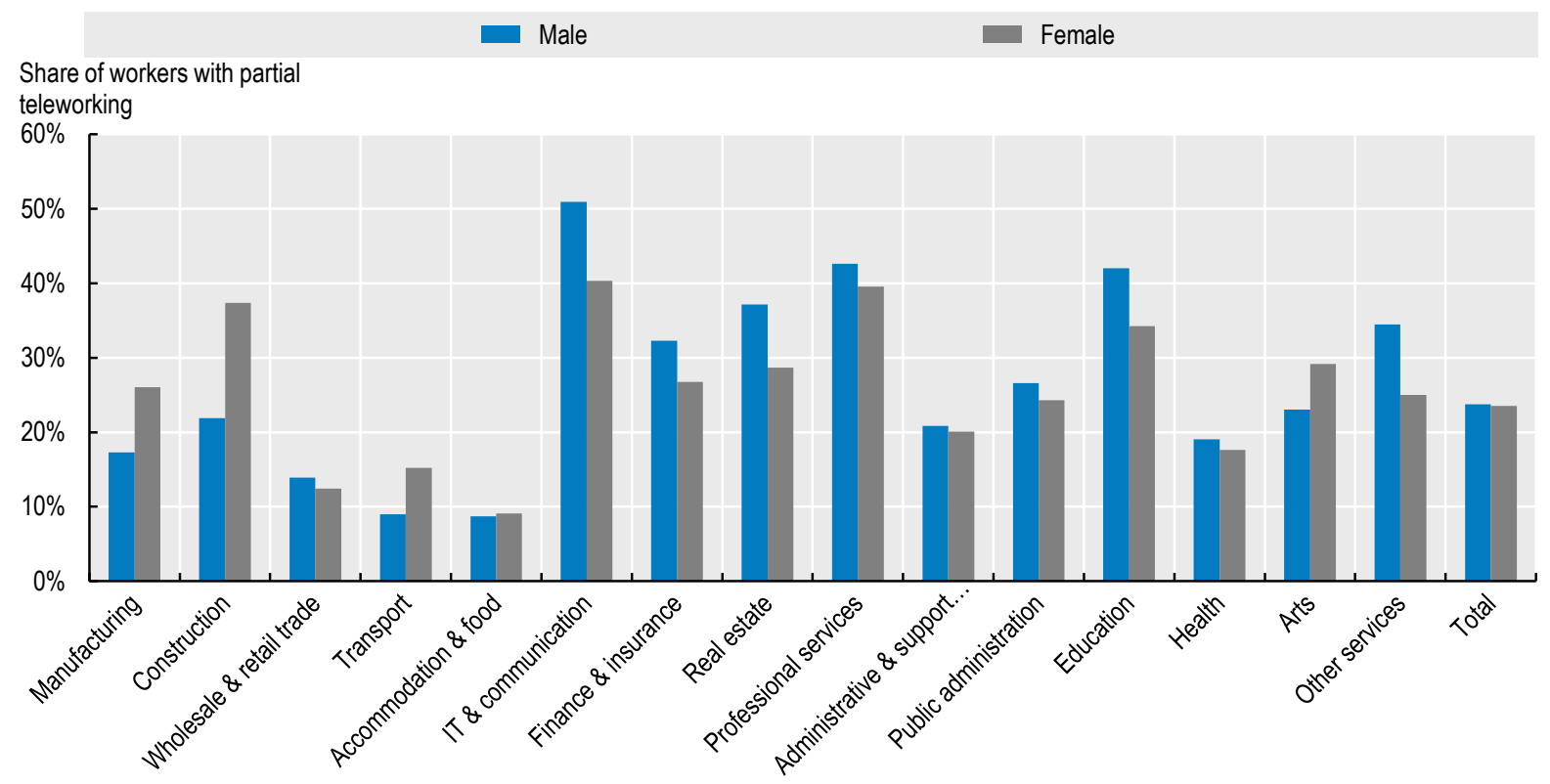

Note: Numbers indicate the share of workers working from home sometimes or usually. All other workers reported never working from home. Source: EU Labour Force Survey for the United Kingdom, 2018.

The prevalence of teleworking differs substantially across sectors. Unsurprisingly, it is most common in IT and communication services and professional services. Workers in the education sector also indicate working from home at least sometimes. However, while working from home might be common to prepare for classes and lectures, physical presence at schools and universities for teaching used to be required for teachers and professors. This changed during the COVID-19 pandemic, but it will have to be seen whether the changes are just temporary. ${ }^{7}$ Teleworking is less prevalent in the accommodation \& food, transport, as well as wholesale and retail trade sectors.

\footnotetext{
5 According to an ONS survey, in $201926.7 \%$ of all employees reported ever having worked from home https://www.ons.gov.uk/employmentandlabourmarket/peopleinwork/employmentandemployeetypes/datasets/homew orkingintheuklabourmarket

${ }^{6}$ According to the ONS Opinions and Lifestyle Survey, around 45\% of adults in employment worked from home at least once in April 2020 and around 40\% in May 2020. Also in February 2021 this number stood at around 45\%. Most common reasons for working from home were being asked by this employer to work from home, following government advice to work from home and the fact that the workplace was completely closed. Only $24 \%$ of those working from home in February 2021 indicated they normally work from home some or all of the time (ONS Opinions and Lifestyle Survey, 26 February 2021).

7 Cambridge University announced that all lectures will be online only until the summer of 2021 (https://www.bbc.com/news/education-52732814). Other universities chose a mix of online lectures and physical presence in classrooms.
} 
The possibility of teleworking exists for both men and women (Figure 35). While the proportion of men and women working from home is almost identical in the economy as a whole, there are some interesting differences across sectors. For example, in the manufacturing and construction sectors, women are more likely to be able to work from home. The opposite is true for most services sectors, including IT \& communication, finance and insurance and professional services. This may be due to the specific occupations of men and women in these sectors.

The analysis shows that teleworking is less prevalent among vulnerable workers. One of the characteristics that best predicts whether a person will work from home is their education. More than $40 \%$ of all workers with at least a bachelor's degree work from home at least sometimes (Figure 36). Amongst workers with short-cycle tertiary education ${ }^{8}$ teleworking is much less prevalent $(27 \%)$. Only $15 \%$ of workers with not more than secondary education work from home. Also, the tenure in a company can explain the individual probability of working from home. Only $15 \%$ of workers who joined a company less than one year ago use teleworking, while the share of teleworking is more than $25 \%$ of those with more than five years of tenure. As mentioned above, while teleworking became much more prevalent since March 2020, it is still relevant to consider the numbers on structural teleworking prior to the COVID-19 pandemic as indicators for the ex ante vulnerability of different groups of workers.

Figure 36. Share of workers with partial teleworking, 2018

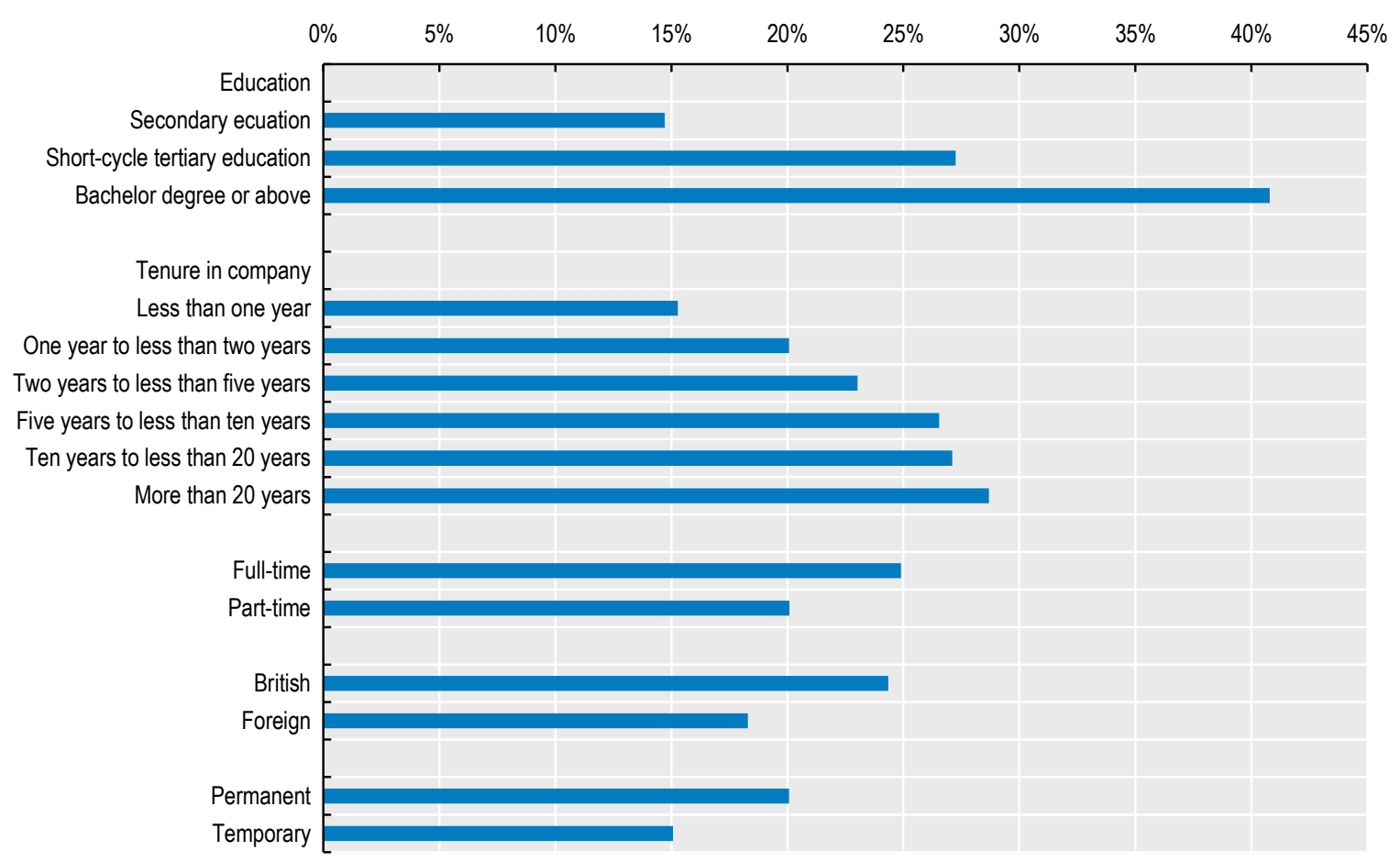

Note: Numbers indicate the share of workers working from home sometimes or usually. All other workers never work from home.

Source: EU Labour Force Survey for the United Kingdom, 2018. Workers in part-time jobs are less likely to be able to work from home than those in full-time occupation. Only $20 \%$ of part-time workers can make use of teleworking while $25 \%$ of full-time employees can work from home at least sometimes. Teleworking is also more widespread among British nationals compared to foreigners and among those with permanent contracts compared to workers with temporary (fixed-term) contracts.

\footnotetext{
${ }^{8}$ This level corresponds to International Standard Classification of Education (ISCED) level 5.
} 


\section{References}

Balassa, B. (1965), Trade Liberalisation and 'Revealed' Comparative Advantage, The Manchester School of Economic and Social Studies, Vol. 33, pp. 99-123.

Benz S., D. Rouzet and F. Spinelli (2020), "Firm heterogeneity in services trade: Micro-level evidence from eight OECD countries", The World Economy, vol. 43(11), Special Issue: The Effects of Services Trade Policies November 2020, pp. 2905-2931.

Dacic, N. and M. Melolinna (2019), "The Empirics of Granular Origins: some Challenges and Solutions with an Application to the UK", Bank of England Staff Working Paper No. 842.

Eckert, F, S Ganapati and C Walsh (2019), "Skilled tradable services: The transformation of US high-skill labor markets", Opportunity \& Inclusive Growth Institute, Federal Reserve Bank of Minneapolis working paper 25.

Eurostat (2019), Services trade by enterprise characteristics - STEC.

Lassmann, A. (2020), "Services trade and labour market outcomes", OECD Trade Policy Papers, No. 239, OECD Publishing, Paris.

López González, J. and S. Sorescu (2019), "Helping SMEs internationalise through trade facilitation", OECD Trade Policy Papers, No. 229, OECD Publishing, Paris.

OECD (2020), United Kingdom Economic Survey, OECD Publishing, Paris.

Riley, R., A. Rincon-Aznar, and L. Samek (2018), "Below the Aggregate: A Sectoral Account of the UK Productivity Puzzle", ESCoE Discussion Paper (06).

Tenreyro, S. (2018, January). The fall in productivity growth: causes and implications. Speech at Peston Lecture Theatre, Queen Mary University of London.

Schneider, P. (2018), "Decomposing Differences in Productivity Distributions", Bank of England Staff Working Paper No. 740. 


\section{Uncover the United Kingdom's domestic policy and regulatory setting for services}

This section examines the regulatory environment faced by UK services firms and UK affiliates of foreign multinationals, with the view to identify potential regulatory impediments that affect the capacity of UK firms to compete in international markets. Restrictive services policies not only limit the ability of services providers to access foreign markets, but also the ability of domestic firms to access services inputs at competitive prices. Services trade barriers, as measured by the OECD STRI, increase services trade costs and are significantly associated with lower services trade. Expressed as percentages of total trade value, average multilateral services trade costs are around $57 \%$ for communication services and $54 \%$ in business services, around $60 \%$ for transport services, around $103 \%$ for insurance services, and around $255 \%$ for financial services (Benz and Jaax, 2020). Given the integration of services and goods production in supply chains, restrictions on services are likely to affect both goods and services-producing firms (Miroudot and Cadestin, 2013).

\section{The regulatory environment is one of the most favourable in the OECD}

Barriers to trade, investment and competition in the services sectors are, in most dimensions, low in the United Kingdom. This creates a more supportive business environment than in most other countries (Figure 37). The United Kingdom is amongst the top 15 best performers in most sectors (Table 3). Exceptions are accounting and motion pictures that are examined in more detail in the subsequent sections. The United Kingdom was not in the top-15 for air transport in 2020 as well, but the removal of foreign equity restrictions in January 2021, is likely to improve the UK score significantly. The UK regulatory framework appears to share a number of similarities, as measured by the OECD index of heterogeneity, with the Netherlands, and to a lesser extent Ireland (see section on regulatory heterogeneity).

Most UK sectors experienced some liberalisation from 2014 to 2016, followed by an increase in the stringency of regulation in 2017 and little change thereafter (Figure 38). 2017 changes reflect the implementation of the new Immigration Skills Charge Regulations. In addition, the new EU General Data Protection Regulation (Regulation No. 2016/679) entered into force on 25 May 2018 providing a comprehensive update on the EU data protection regime. A number of professional services (legal, accounting, architecture, engineering) experienced a tightening of policies during the whole period. The immigration system was also changed. 
Figure 37. UK Services Restrictiveness Index by sector, 2020

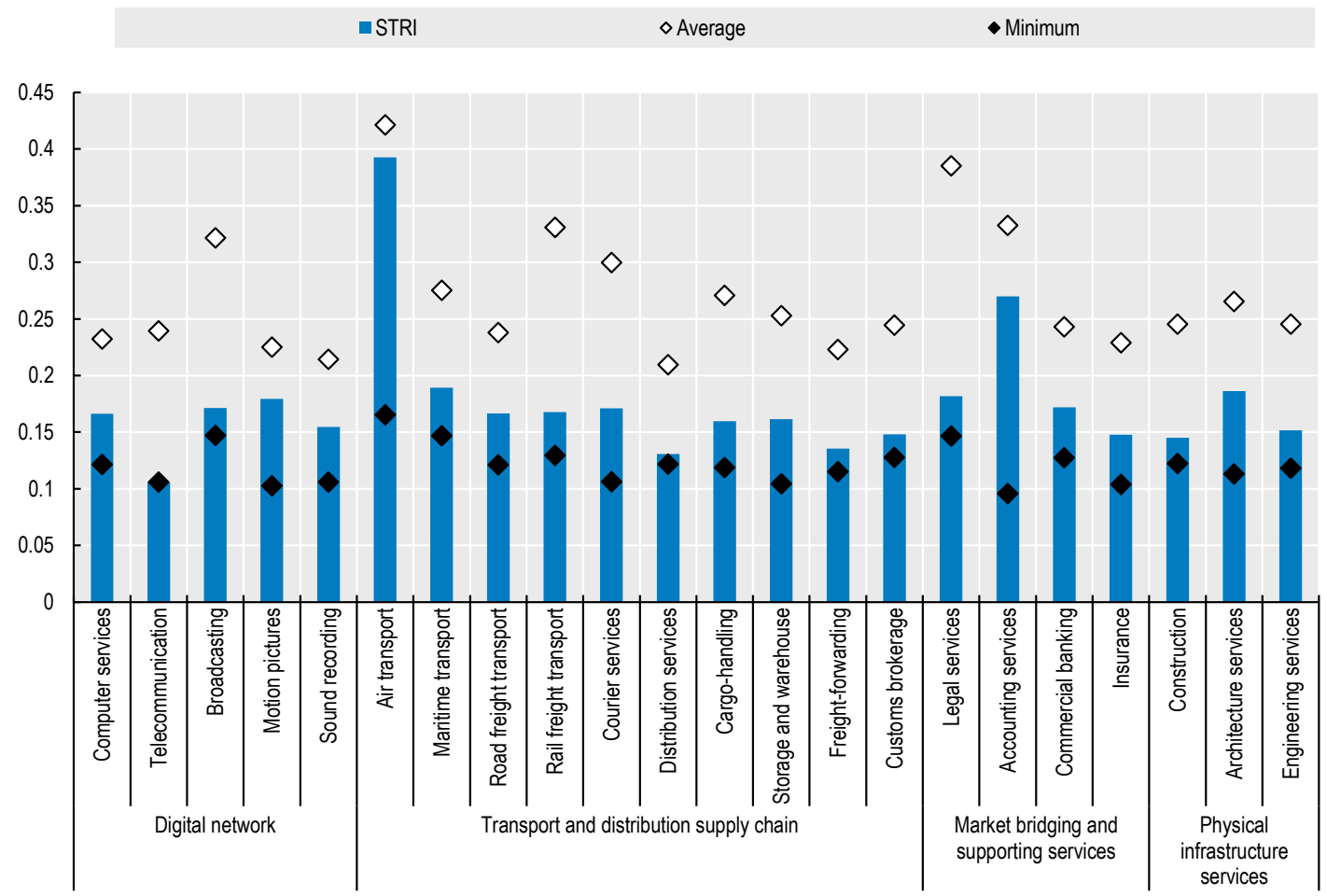

Note: The STRI indices take values between zero and one, one being the most restrictive. The STRI database records measures on a Most Favoured Nations basis. Preferential trade agreements are not taken into account. Air transport and road freight cover only commercial establishment (with accompanying movement of people). The indices are based on laws and regulations in force on 31 October 2020. The average is computed over the 48 countries covered by the STRI.

Source: STRI regulatory database.

Figure 38. UK Services Trade Restrictiveness Index, percentage change over the period 2014-2016, 2016-2019 and 2019-2020

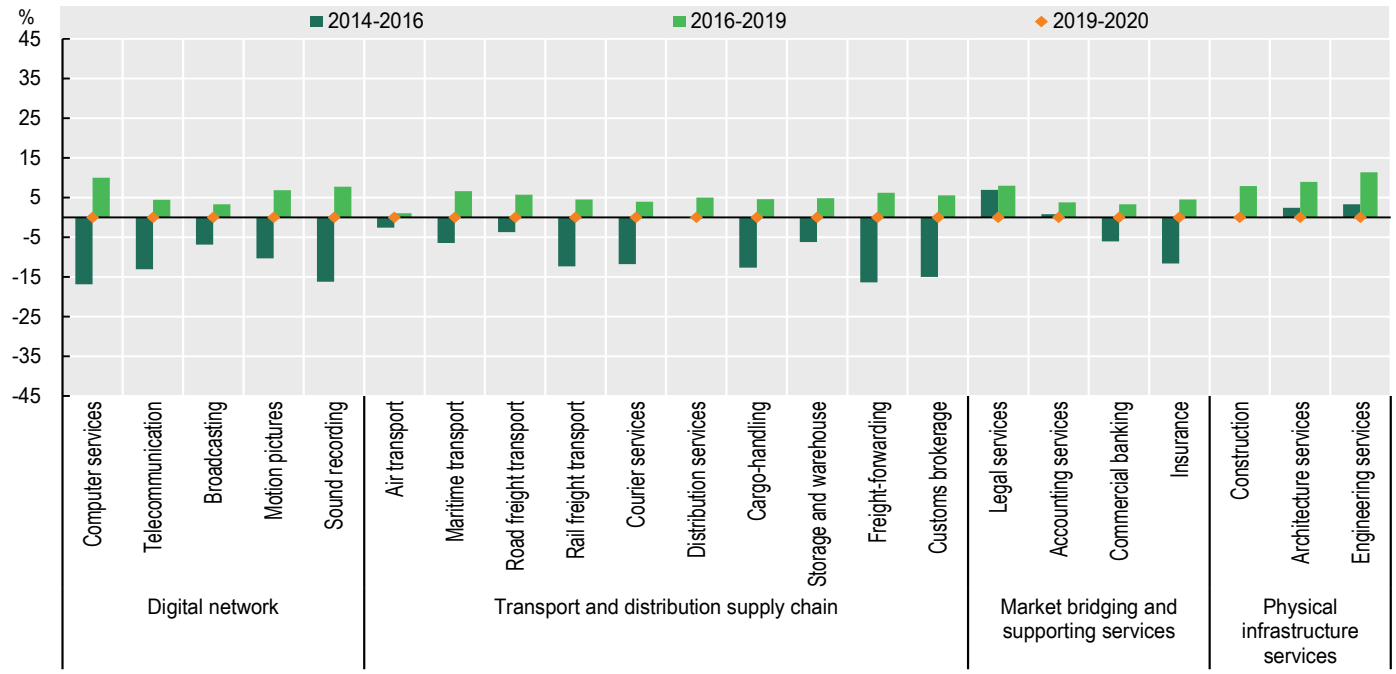

Note: The STRI indices take values between zero and one, one being the most restrictive. The STRI database records measures on a Most Favoured Nations basis. Air transport and road freight cover only commercial establishment (with accompanying movement of people). The indices are based on laws and regulations in force on 31 October 2020.

Source: STRI regulatory database. 
Table 3. STRI ranking by sector, 2020

\begin{tabular}{l|l|c}
\hline & \multicolumn{1}{|c}{ Top 3 countries } & Rank United Kingdom \\
\hline Accounting & Chile, Czech Republic, Latvia & 21 \\
\hline Air transport & Chile, Columbia, Brazil & 17 \\
\hline Architecture & Latvia, Chile, Netherlands & 12 \\
\hline Broadcasting & Portugal, Luxembourg, Netherlands & 4 \\
\hline Commercial banking & Spain, Czech Republic, Ireland & 12 \\
\hline Computer services & Korea, Czech Republic, France & 9 \\
\hline Construction & Japan, France, United Kingdom & 3 \\
\hline Courier services & France, Netherlands, Czech Republic & 10 \\
\hline Distribution services & Czech Republic, Japan, Chile & 4 \\
\hline Engineering & Japan, France, Latvia & 5 \\
\hline Insurance & France, Korea, Czech Republic & 11 \\
\hline Legal services & Latvia, Australia, Costa Rica & 9 \\
\hline Logistics- cargo-handling & Denmark, Czech Republic, Lithuania & 9 \\
\hline Logistics - customs brokerage & Czech Republic, France, Netherlands & 6 \\
\hline Logistics - freight forwarding & Czech Republic, France, Netherlands & 5 \\
\hline Logistics- storage and warehouse & Korea, Czech Republic, Lithuania & 9 \\
\hline Maritime transport & Netherlands, Latvia, Portugal & 7 \\
\hline Motion picture & Japan, Czech Republic, Portugal & 16 \\
\hline Rail freight transport & Netherlands, United States, Canada & 6 \\
\hline Road freight transport & Czech Republic, Japan, Chile & 11 \\
\hline Sound recording & Japan, Korea, Latvia & 9 \\
\hline Telecommunication & United Kingdom, Denmark, Germany & 1 \\
\hline
\end{tabular}

Note: Ranks are an average of ranks across measures in each sector.

Source: STRI regulatory database.

\section{Box 3. What is the Services Trade Restrictiveness Index?}

The OECD Services Trade Restrictiveness Index (STRI) provides information on regulations that affect trade in services in 22 sectors across 48 countries, including all OECD countries and several emergingmarket economies.

The STRI covers limitations on market access and national treatment, as well as national regulatory and competition policies which apply to both national/resident and foreign/non-resident companies, and investment policies. The policy measures accounted for in the STRI database are organised under five policy areas.

- Restrictions on foreign entry include information on foreign equity limitations, requirements that management or board of directors must be nationals or residents, foreign investment screening, restrictions on cross-border mergers and acquisitions, capital controls and a number of sectorspecific measures.

- Restrictions on movement of people include information on quotas, economic needs tests and duration of stay for foreign natural persons providing services as intra-corporate transferees, contractual services suppliers or independent service suppliers, and recognition of foreign qualifications in regulated professions. 
- Other discriminatory measures include discrimination of foreign services suppliers as far as taxes, subsidies and public procurement are concerned; and instances where national standards differ from international standards where relevant.

- Barriers to competition include information on anti-trust policy, government ownership of major firms and the extent to which government-owned enterprises enjoy privileges and are exempted from competition laws and regulations. Sector-specific pro-competitive regulation in network industries also falls under this category.

- Regulatory transparency includes information on consultations and publications prior to entering into force of laws and regulations. It also records information on administrative procedures related to establishing a company, obtaining a license or a visa. The STRI reviews regulations currently in force and does not take into account preferential trade agreements. The STRI database is updated every year and countries covered are given the opportunity to comment on, and discuss, the accuracy of the information therein.

Further information can be found in Trade Policy Paper №177 and Policy trends up to 2020.

\section{The general economic environment is favourable}

While the UK regulatory framework is overall very favourable to firms and compares well with other OECD countries, a number of economy-wide regulations contribute to the stringency of the general regulatory environment (Figure 39). Those restrictions are to a large extent related to movement of people (Mode 4). Up until December 2020, the United Kingdom applied labour-market tests to workers seeking to provide services on a temporary basis as intra-corporate transferees or independent suppliers. Professionals in these categories may, however, stay in the country for up to five years on their first entry permit, or up to nine years for those earning more than GBP 74,000 (ICTs), or up to six months for IPS with EU or Swiss nationality can stay for up to 12 months. Contractual services suppliers pertaining to a limited list of occupations may be admitted without labour-market tests, but under this route they cannot stay in the United Kingdom for more than 6 months in any 12-month period. As of 2021, EU and Swiss nationals will be able to stay up to 12 months. UK and EU nationals will also be able to move as contractual service suppliers and independent (self-employed) professionals, within particular sectors, for stays of up to 12 months. Those features were not uncommon. For instance, in the telecommunications sector, amongst the 48 covered by the STRI database, the duration of stay is limited to less than three years in 39 countries.

The new Points-Based system came into effect on 1 December 2020 (Box 3.2). Those changes have not been incorporated in the STRI, whose cut-off-date was October 2020. As of 31 December 2020, EU nationals, have been subject to same rules as non-EU nationals. The new system will bring in a pointsbased system to cater for highly skilled workers, skilled workers, students and a range of other specialist work routes including routes for global leaders and innovators.

Furthermore, rights of access to public procurement are limited to regional trade agreement partners and members of the WTO's Government Procurement Agreement. 
Figure 39. Contributions to the services trade restrictions in the United Kingdom, Services Trade Restrictiveness Index, 2020

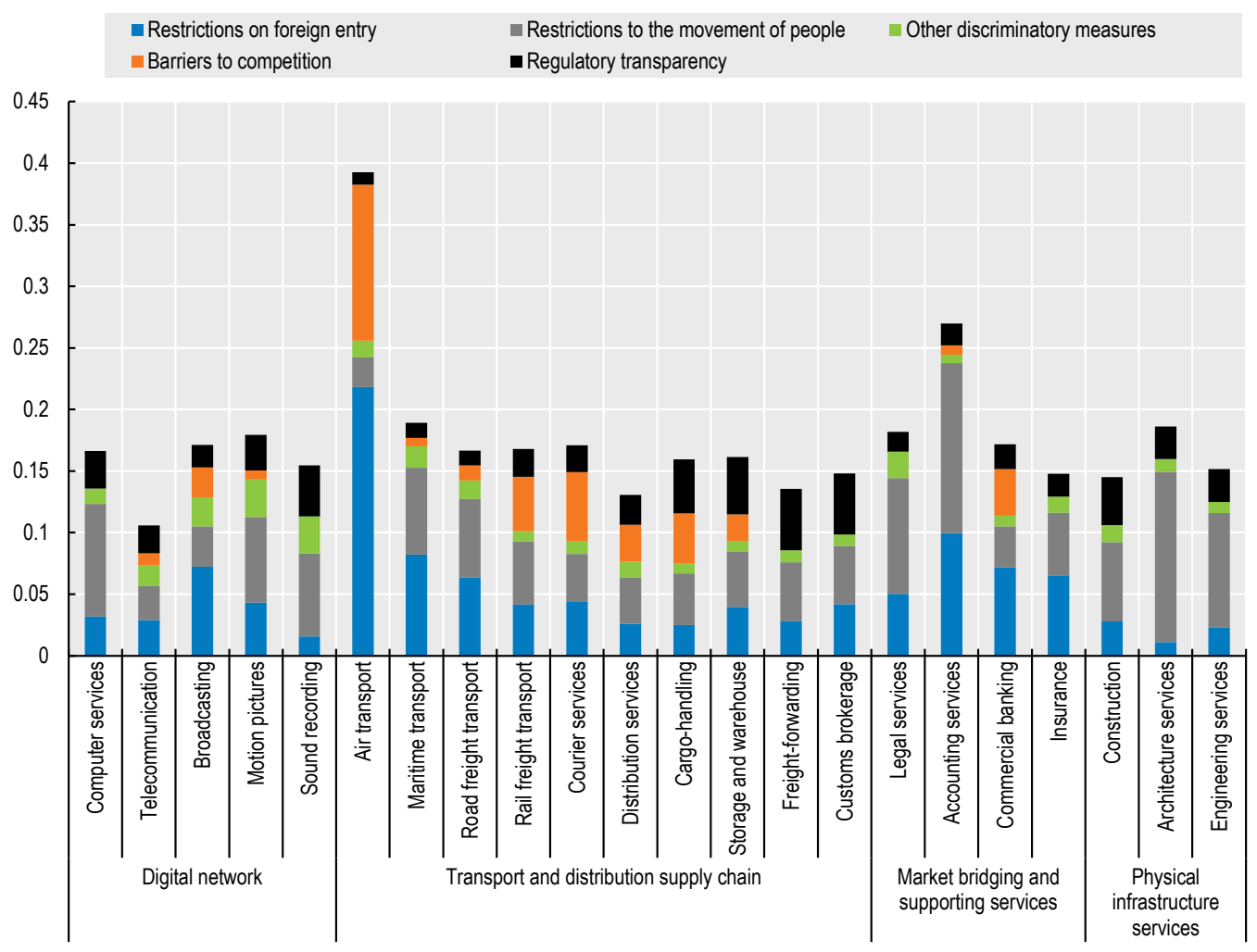

Note: The STRI indices take values between zero and one, one being the most restrictive. They are calculated on the basis of the STRI regulatory database which contains information on regulation for the 36 OECD Members, Brazil, China, Colombia, Costa Rica India, Indonesia, Malaysia, Russia, South Africa, and Thailand. The STRI database records measures on a Most Favoured Nations basis. Preferential trade agreements are not taken into account. Air transport and road freight cover only commercial establishment (with accompanying movement of people). The indices are based on laws and regulations in force on 31 October 2020.

Source: STRI regulatory database.

\section{Box 4. The UK's new points-based immigration system}

The UK's new points-based immigration system was introduced on 1 December 2020.

The new Skilled Worker route is for employers to recruit people to work in the United Kingdom in a specific job. A Skilled Worker must have a job offer in an eligible skilled occupation from a Home Officeapproved sponsor. The salary threshold is now GBP 25 600, down from GBP 30000 in the previous system. There is no limit on the number of skilled workers who can come to the United Kingdom. The Resident Labour Market Test was removed. Finally, the skills threshold was broadened from jobs skilled to RQF Level 6 (degree-equivalent) to RQF Level 3 (A-Level equivalent) - although employees will not need to show qualifications. This change roughly doubles the number of eligible occupations and gives UK employers more freedom to fill skilled vacancies in their business.

The new, updated Intra-Company Transfer route is for established workers who are being transferred by the business they work for to do a skilled role in the United Kingdom. Switching to different routes from inside the country is now allowed, giving both employers and workers more freedom to develop their career on this visa (though the ICT route will not count to settlement). A flexible cooling-off period was introduced. It allows five years out of every six to be spent in the United Kingdom on this visa. This removes the mandatory one-year cooling off period after each visa that previously existed. 
In terms of foreign-entry restrictions, the United Kingdom has stricter conditions on the transfer of personal data than recommended in the OECD Guidelines for Protection of Privacy and Transborder Flow of Personal Data. This is not uncommon, however, as the vast majority of countries covered by the STRI database are in a similar situation. The standards for cross-border transfer of personal data are set at the EU level, until the end of 2020. The EU General Data Protection Regulation (Regulation 2016/679) entered into force on 25 May 2018 and provided a comprehensive update on the EU data protection regime. Transfers to non-EEA economies can take place when these ensure an adequate level of data protection or, in the absence of this, when appropriate safeguards (e.g. binding corporate rules or standard data protection clauses) are in place. In 2019, the United Kingdom reformed this law to prepare the posttransition period and referred to an UK-specific data protection regulation.

\section{Sector-specific restrictions remain limited}

This section reviews the sectors where the United Kingdom does not rank in the top 15 performers amongst the 48 countries covered by the STRI, or sectors that are key to facilitate the transition to a digital economy. In all these sectors the UK scores remain below the average across countries, pointing to a more liberal environment than in the average of OECD countries.

\section{Air transport}

Air transport services are not only significantly traded in their own right but are an intermediate service for other kinds of trade. Air cargo transport is also a key determinant in meeting demand for time sensitive products, such as perishable goods and often represents the only viable means of transport to remote, peripheral regions and landlocked countries. It has been particularly affected worldwide by travel restrictions introduced since the outbreak of coronavirus.

The 2020 UK STRI index in the air transport services sector is close to the average across countries but still well below the maximum (Figure 40). Countries with a similar score include Austria, Japan or the Netherlands. Apart from a few exceptions, there is limited variation across countries.

Restrictions on foreign entry contributed the most to the stringency of regulation in the sector in the United Kingdom. Foreign-equity restrictions on ownership of UK airlines were lifted on 1 January 2021. Up until the end of the transition period in December 2020, foreign equity restrictions were introduced in line with the common EU regulation on air services, according to which non-EU nationals cannot own more than $49 \%$ in local airlines. Lease of foreign aircrafts with crew from outside the European Union can be refused on grounds of reciprocity or conditioned on approval granted on the basis of economic needs. An EU-wide exemption of certain airline arrangements from competition law, and regulations on airport slot allocation and slot trading further contributed to the 2020 STRI score in this sector.

Such restrictions are common. A large number of countries (40) restrict foreign equity participation in the sector to (at least) less than $50 \%$. In most cases, the limitations affect airlines in both domestic and international traffic. Notable exceptions include Chile, Colombia, and Costa Rica, which do not apply any limitations on foreign ownership of domestic airlines. Australia (with the exception of Qantas) and New Zealand also allow airlines that are $100 \%$ foreign owned to carry traffic between two domestic airports, whereas Mexico and Japan allow complete foreign ownership in domestic airlines carrying international traffic only. Contrary to what is observed in most countries, the United Kingdom does not couple ownership restrictions with specific limitations on the nationality of board members and managers of air carriers. 
Figure 40. Services Trade Restrictiveness Index in air transport, 2020

\section{A. Comparison across countries}

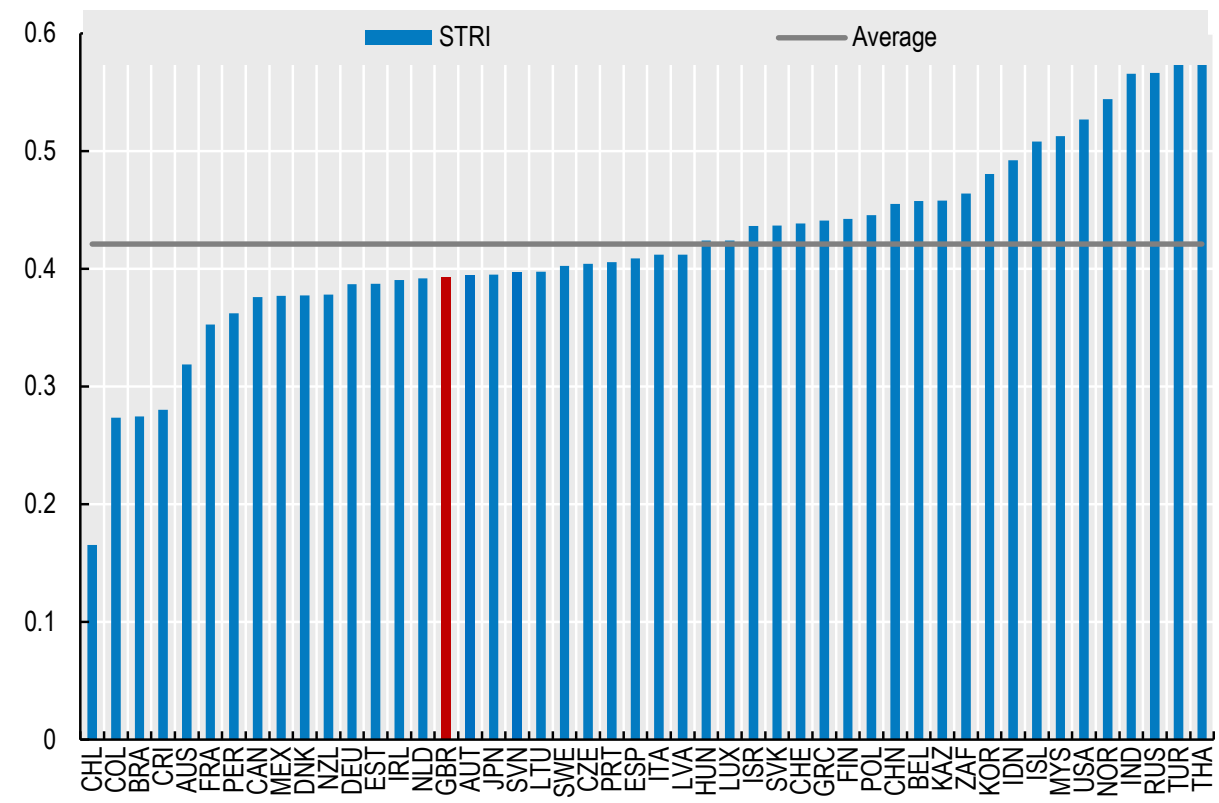

B. Breakdown and comparison with best performers

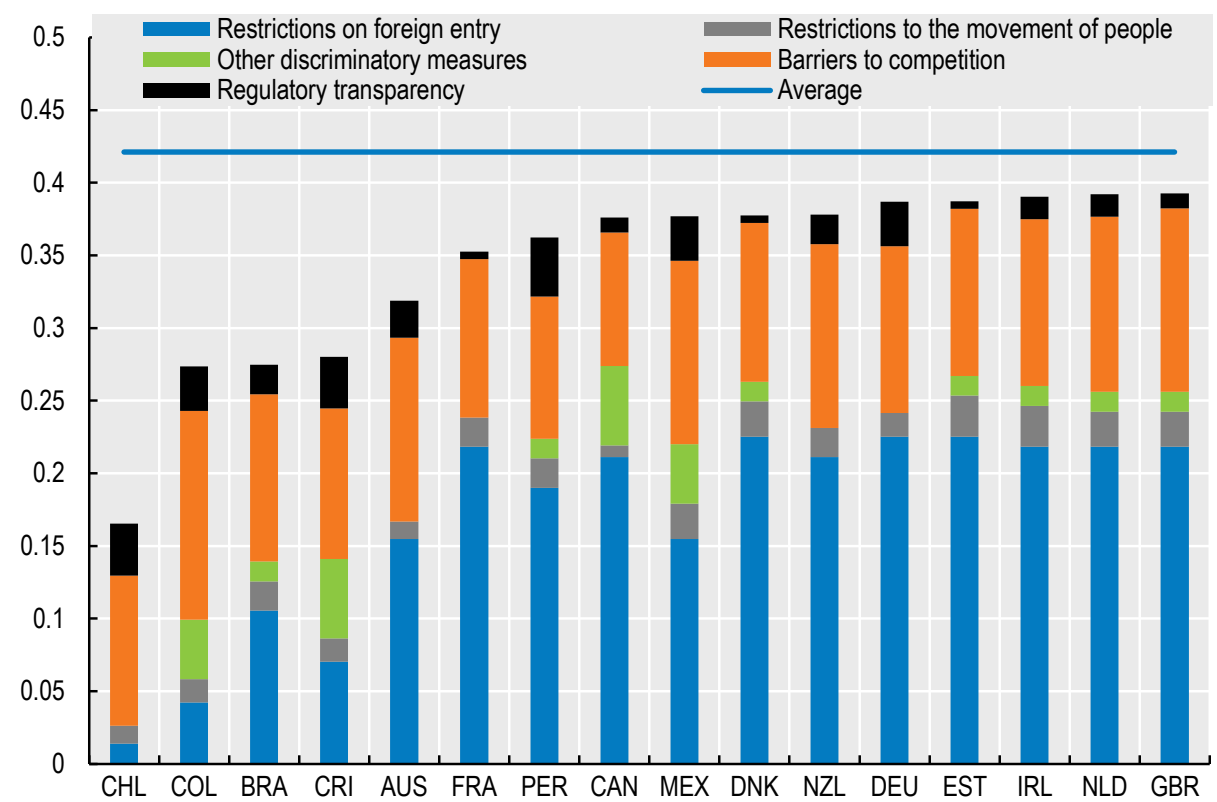

Note: The STRI indices take values between zero and one, one being the most restrictive. They are calculated on the basis of the STRI regulatory database which records measures on a Most Favoured Nations basis. Preferential trade agreements are not taken into account. The indices are based on laws and regulations in force on 31 October 2020. Air transport services are defined as passenger and freight air transport (ISIC 51), carried domestically or internationally. The STRI for this sector covers commercial establishment only.

Source: STRI regulatory database. 
Similarly to many other countries, the United Kingdom prohibits or restricts certain categories of lease of foreign aircrafts. The lease of foreign aircrafts without crew (dry lease) is permitted subject to prior authorisation in cargo and passenger flights. The lease of foreign aircrafts with crew (wet lease) is effectively prohibited in 28 other countries, whereas in 14 others it is subject to prior approval. Leasing foreign aircrafts without crew (dry lease) is subject to prior authorisation in 40 countries.

The other main category that influences the degree of restrictiveness is related to the horizontal restrictions on the movement of people providing services on a temporary basis as intra-corporate transferees, contractual services suppliers or independent services suppliers (see above). The United Kingdom does not seem to differ on this dimension from best-performers in this sector.

The STRI index goes beyond discriminatory measures and includes domestic regulations that are important for effective market access and the creation of competitive markets. These measure impediments to competition and technical standards, as well as a range of measures related to regulatory transparency and administrative requirements.

Like most best-performer countries, the United Kingdom imposes barriers to competition and other discriminatory measures, including regulations related to taxes, subsidies and public procurement. Like in most countries, slots are assigned in high demand airports based on historical rights, typically forbidding the commercial exchange of slots. However, similarly to what can be observed in most countries, after the allocation of historic slots, half of the remaining slot pool is allocated to new entrants.

Finally, regulatory transparency is also an area that contributes to the stringency of regulation in the sector. This policy area builds on information from administrative laws and regulations, information from the migration authorities on requirements for obtaining a business visa and the World Bank Doing Business Survey. The United Kingdom is among the 40 best performing countries in the latter Survey. This explains the UK score in this area to a large extent, in addition to lengthy, costly and complex regulatory procedures related to obtaining a business visa.

\section{Road freight transport}

Road freight transport is not only extensively traded but it is also an intermediate service at the core of recent developments in network production, global value chains and just-in-time supply management, with the related demand for door-to-door services. The sector plays an important role in market integration and is an intermediate input for other kinds of trade, particularly trade in goods but also in other services (e.g. distribution services and logistics).

The STRI for this sector covers commercial establishment only. Cross-border trade is governed by a system of bilateral and multilateral agreements which provide for permits, quotas and other regulations. OECD estimates suggest that on average across countries halving the distance to best practice in this sector is associated with between $12 \%$ and $20 \%$ boost in trade in manufactured goods such as motor vehicles, electrical equipment and chemicals (Nordas and Rouzet, 2015).

The STRI for the United Kingdom in the road freight transport sector is well below the average (Figure 41). It is very similar to those of the United States, Slovak Republic or France. Best performers in the sector are Czech Republic, Japan and Chile while most emerging market economies are characterised by more restrictive regulatory frameworks. 
Figure 41. Services Trade Restrictiveness Index in road freight transport, 2020

A. Comparison across countries

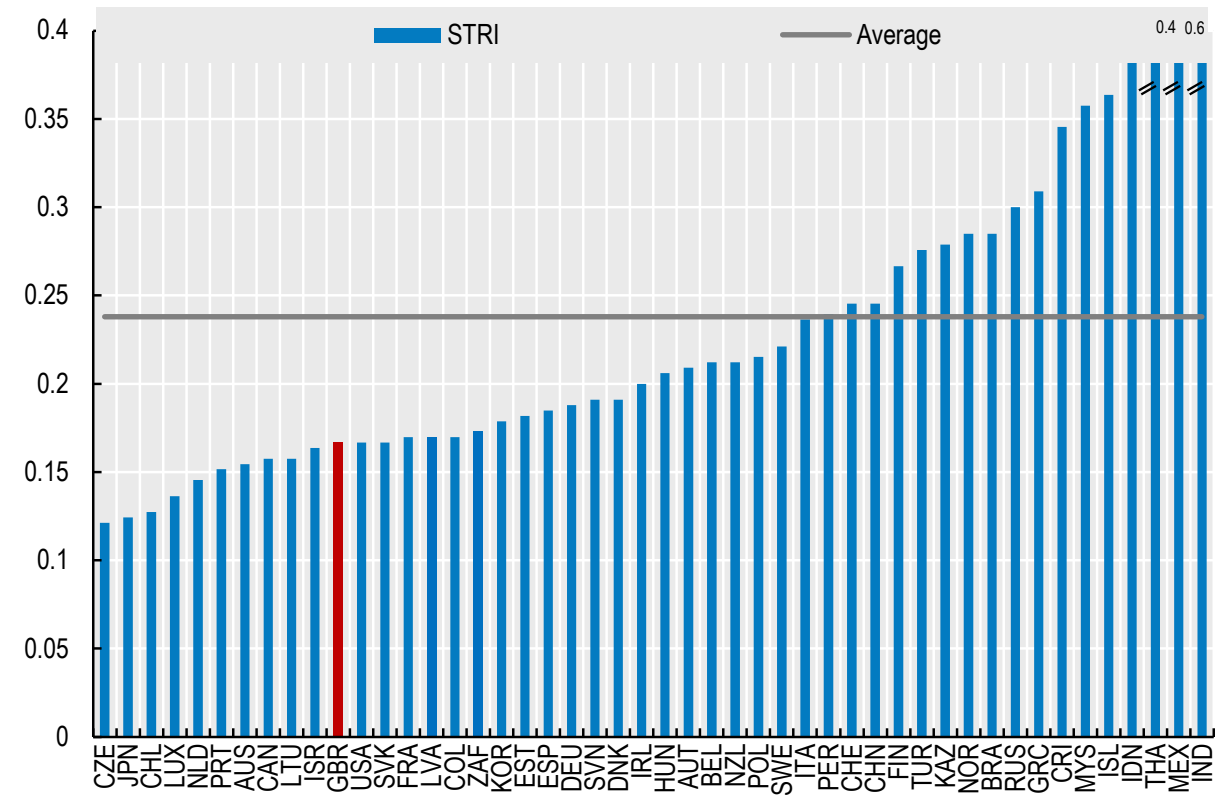

B. Breakdown and comparison with best performers

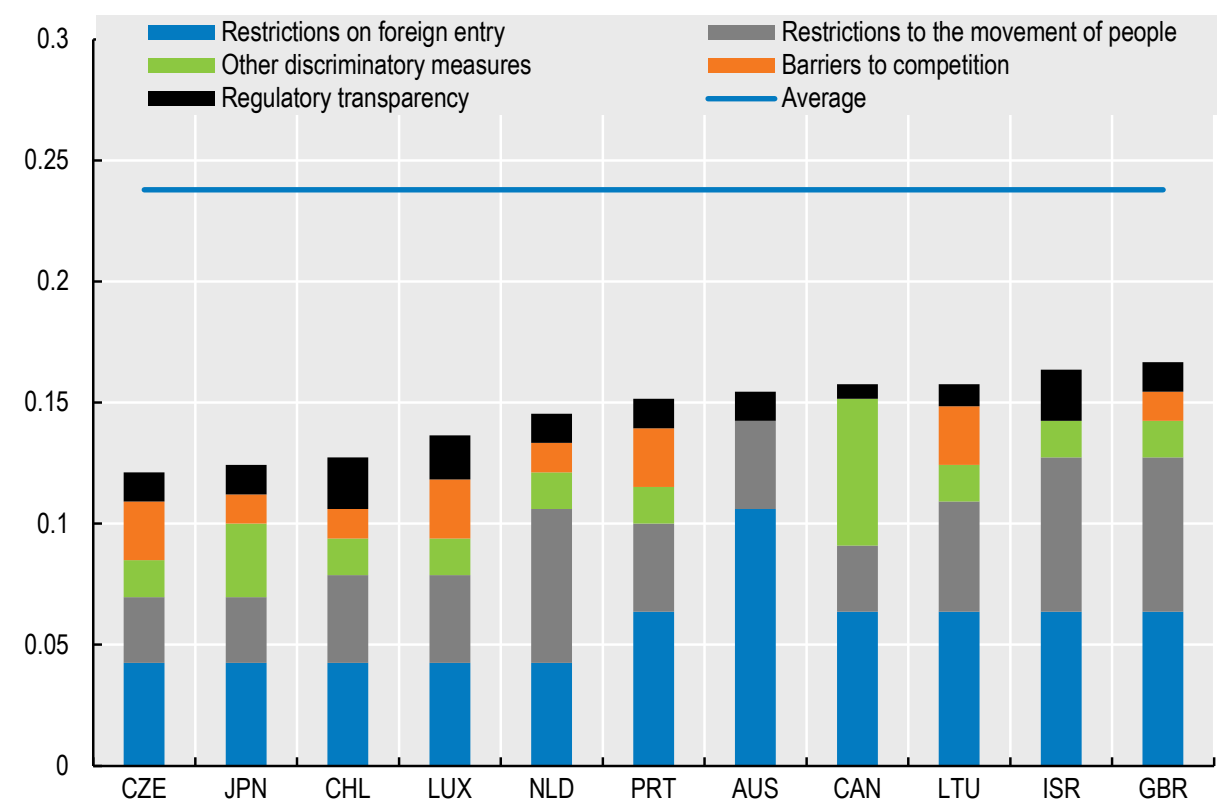

Note: The STRI indices take values between zero and one, one being the most restrictive. They are calculated on the basis of the STRI regulatory database which records measures on a Most Favoured Nations basis. Preferential trade agreements are not taken into account. The indices are based on laws and regulations in force on 31 October 2020. Road freight transport is defined as ISIC (rev 4) category 4293 freight transport by road.

Source: STRI regulatory database. 
Restrictions on foreign entry are on average more prevalent in the United Kingdom than in the best performing countries. Transport managers must be resident in the United Kingdom or in the European Union and screening exists without exclusion of economic interests. Those restrictions are however commonly used. Residency requirements for managers apply in 33 countries and are in EU legislation. A license is required to operate road transport services in many countries and in three of them licensing is conditional on economic needs. Eight additional countries impose economic needs tests on foreign investment in the sector. In addition, the transfer of personal data in the United Kingdom is possible to countries with substantially similar privacy protection laws.

Restrictions on the movement of people in the UK road freight transport sector are also more stringent than in best performers countries. All the countries in the STRI database have some forms of restrictions on the movement of people providing services on a temporary basis as intra-corporate transferees, contractual services suppliers or independent services suppliers. Twelve countries provide established processes and criteria for recognition of foreign qualifications on an MFN basis.

Other forms of restrictions are comparable or even sometimes lower than what exists in the best performer countries. Restrictions to competition are low compared to those that exist in best performer countries. The United Kingdom like Japan, the best performer in this sector, does not explicitly prohibit discrimination of foreign suppliers. 23 countries have preferential measures for local suppliers or limit non-discriminatory access to public procurement to free trade agreement or WTO government procurement agreement (GPA) partners. The only key restriction in this area is that the United Kingdom exempts road freight carrier's agreements from competition law. Such a restriction exists in 25 other countries.

Restrictions regarding regulatory transparency are also limited in the United Kingdom when compared with best performers. The main ones concern the length and the cost of visa process, and the time taken for customs clearance. Other countries such as Japan or Canada have simpler processes.

While services trade restrictions are usually similar across the four UK nations, road transport stands out as an exception. Indeed legislative provisions on licensing in Northern Ireland are different from those existing in the rest of Great Britain and could lead to some forms of discrimination (Shepherd, 2019). In England, Wales, and Scotland, the law requires an operator seeking a license to be established in Great Britain. In Northern Ireland, the law requires an operator to be established in Northern Ireland, so establishment elsewhere in the United Kingdom would appear to be insufficient to support a license application.

\section{Accounting, auditing and book-keeping services}

The international market for accounting services, auditing and book-keeping services is dominated by a handful of corporations characterised by a high degree of concentration, organised as a network, and generally owned and managed independently with presence in a large number of countries.

The STRI score for the United Kingdom in this sector is well below the average across countries (Figure 42). In 2020, the country displayed a score similar to those of Hungary, South Africa or Denmark, markedly above those of the best performers which are Chile, Czech Republic and Latvia.

Like most countries the United Kingdom places restrictions on the ownership and management of audit firms: a majority of the individuals (and firms) who own or manage firms must be eligible for approval as a statutory auditor in the United Kingdom. There is no foreign equity limits in accounting services in the United Kingdom, as is the case in most OECD countries. 
Figure 42. Services Trade Restrictiveness Index in accounting and auditing, 2020

A. Comparison across countries

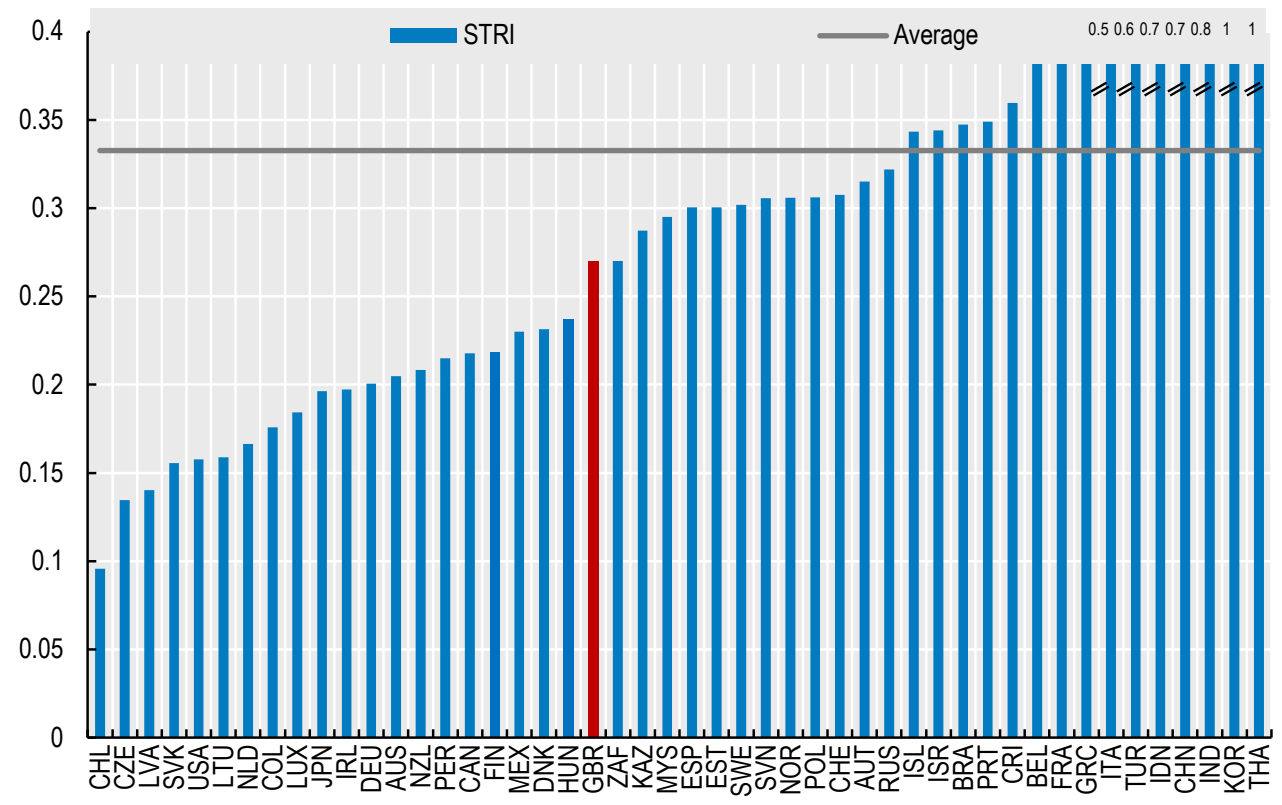

B. Breakdown and comparison with best performers

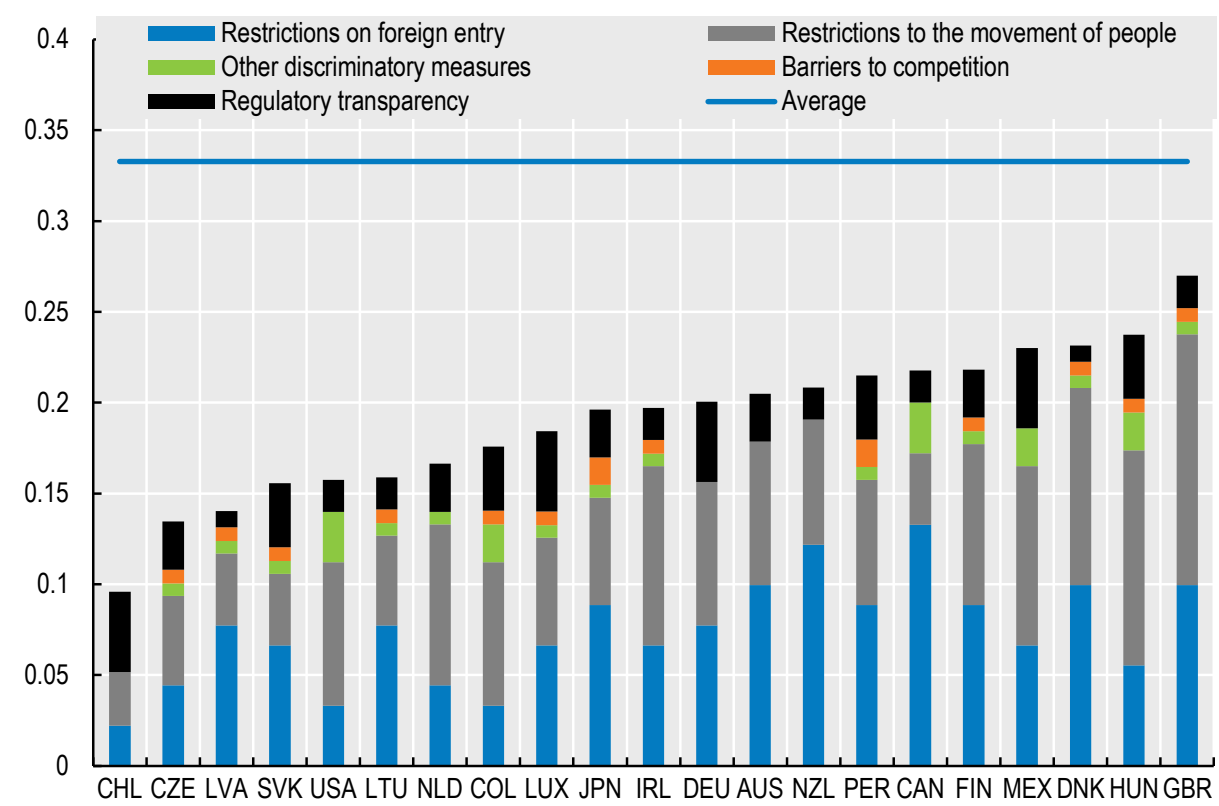

Note: The STRI indices take values between zero and one, one being the most restrictive. They are calculated on the basis of the STRI regulatory database which records measures on a Most Favoured Nations basis. Preferential trade agreements are not taken into account. The indices are based on laws and regulations in force on 31 October 2020. The sector covers ISIC Rev 4 code 692.

Source: STRI regulatory database.

Accountants and auditors are subject to economy-wide limitations on natural persons seeking to provide services on a temporary basis as intra-corporate transferees, contractual services suppliers or independent services suppliers. The United Kingdom imposed labour-market tests up until 2020, but those restrictions 
were lifted for any category of worker since. Limits the duration of stays for contractual and independent service suppliers are six months and five years for intra-corporate transferees. All the 48 countries covered by the STRI limit market access to services providers on a temporary basis either by quotas, economic need test or limitation of duration of stay for less than three years. Common limitations include nationality and residency requirements to practice, as well as lack of recognition of foreign qualifications. Additional limitations include restrictions on fee-setting and advertising.

Market access for foreign suppliers is limited because statutory auditors are required to hold authorised qualifications that cover specific aspects of UK tax and company law. The United Kingdom, like 20 other countries, does not require a license to practice accounting services, but requires one for auditing. This is common practice: auditing is a regulated profession in every country except Chile. Individuals holding third qualifications are able to seek approval to provide audit services in the United Kingdom, but only if the UK regulator has reached an agreement with the relevant third country regulator to recognise one another's qualifications'

The United Kingdom does not impose other discriminatory measures such as regulation related to taxes, subsidies and public procurement. Three countries report areas where national treatment is not fully granted regarding taxes or subsidies, while 22 countries limit non-discriminatory access to public procurement to free trade agreement or WTO government procurement agreement (GPA) partners.

Barriers to competition do not appear widespread or particularly pernicious in this sector. The most common measure under this policy area is minimum capital requirements found in 28 countries. Such a requirement does not exist in the United Kingdom.

The regulatory transparency policy area builds on information from administrative laws and regulations, information from the migration authorities on requirements for obtaining a business visa and the World Bank Doing Business Survey. The United Kingdom performs relatively well in this area compared to the best performers, reflecting essentially its good score in the World Bank Doing Business Survey and average performance in terms of time and costs to get a visa.

\section{Architectural services}

Architectural services constitute the backbone of the construction sector, with key roles in building design and urban planning. An important feature is the regulatory complementarity between architecture, engineering and construction services. Architectural and engineering activities are often combined into projects offered by one company and are sometimes subsumed in the building and construction sector.

The STRI score for the United Kingdom in this sector is well below the average across countries (Figure 43). In 2020, the country displayed a score similar to those of Finland, Luxembourg or Australia, above those of the best performers which were Latvia, Chile and the Netherlands. These services are less restrictively regulated on average than other accredited professional services, notably legal and accounting services.

Architectural services are very labour-intensive and sensitive to restrictions on the movement of people. The latter are common in OECD and emerging-market economies. Economy-wide limitations apply on the ability to provide services on a temporary basis as intra-corporate transferees, contractual services suppliers or independent services suppliers. In addition, architects are subject to licensing requirements, including nationality and residency requirements to practice, and lack of recognition of foreign qualifications. Nine countries do not require a license to practice architecture. This does not necessarily mean that there is less government control during the process of designing and constructing a building or infrastructure projects. Regulations may in some countries be entailed in building codes, technical standards and their enforcement. 
Figure 43. Services Trade Restrictiveness Index in architectural services, 2020

A. Comparison across countries

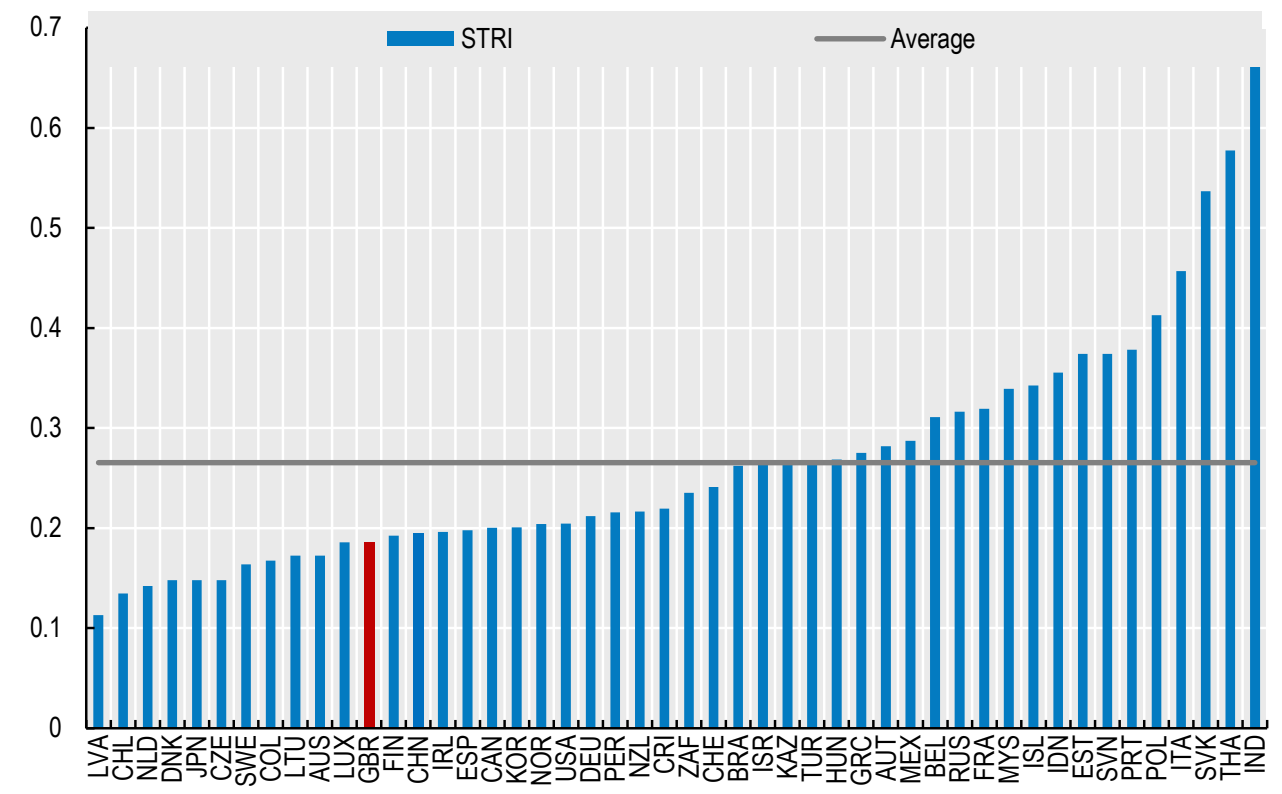

B. Breakdown and comparison with best performers

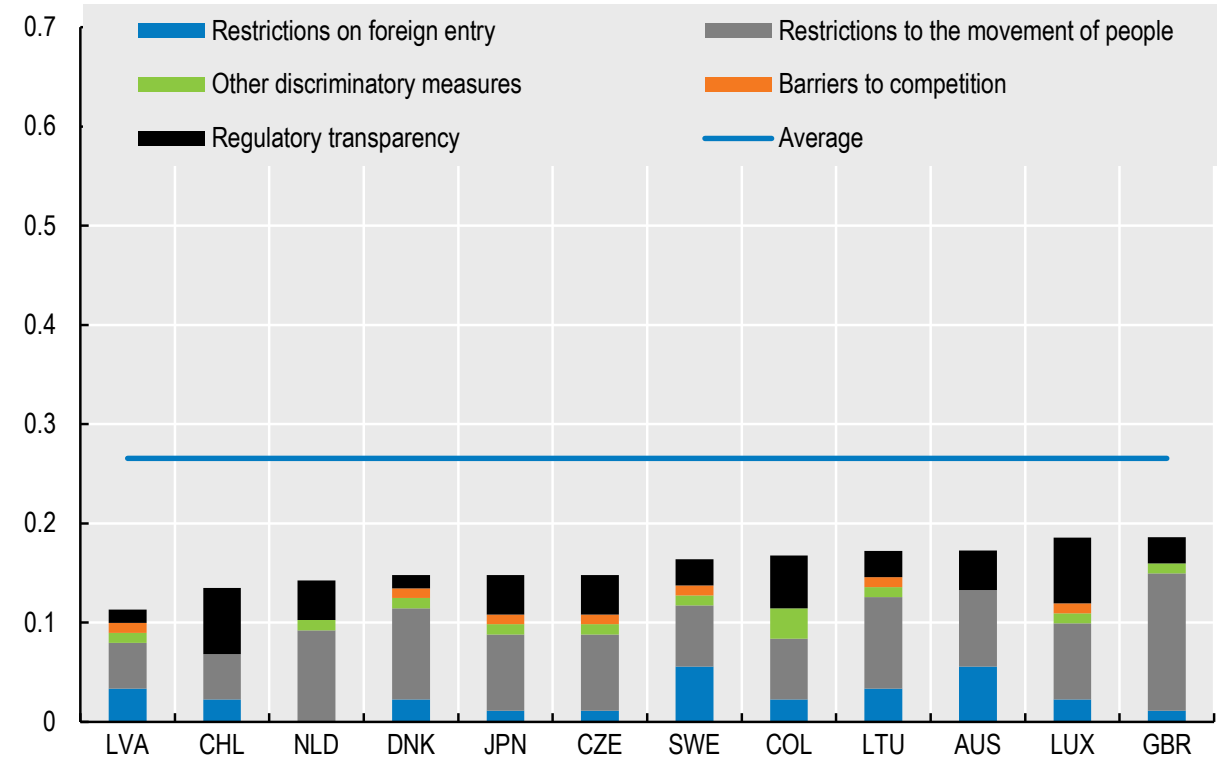

Note: The STRI indices take values between zero and one, one being the most restrictive. They are calculated on the basis of the STRI regulatory database which records measures on a Most Favoured Nations basis. Preferential trade agreements are not taken into account. The indices are based on laws and regulations in force on 31 October 2020. The sector covers architectural services and related technical consultancy (ISIC Rev 4 code 711).

Source: STRI regulatory database. 
A number of restrictions on movement of people exist in the United Kingdom, while they do not in Latvia the best performer country in this sector. In particular, the duration of stay for contractual services suppliers is limited to less than 12 months. Foreign professionals are required to take a local examination and to practice locally for at least one year. A temporary licensing system is in place.

There are relatively few restrictions on foreign entry in the UK architecture services. Such restrictions have a large impact on a few countries. Several countries limit the ownership of architectural firms to locallyqualified architects. Ownership restrictions are often coupled with requirements that the majority of the board (or equity partners in the case of partnerships) and the manager of architectural firms must be locally qualified. Another impediment relates to restrictions on acquiring land and real estate. These may be particularly pernicious for architectural services in light of the complementarities with the building industry.

The United Kingdom has no barriers to competition in the sector, as captured by the STRI. Some of these barriers remain in place in several countries, particularly on fee-setting and advertising.

Impediments to public procurement can play a significant role for architectural services in light of the link with construction. The United Kingdom has introduced discriminatory measures related to public procurement. Twenty-two other countries, including Latvia the best performer country in this sector, have preferential measures for local suppliers or limit non-discriminatory access to public procurement to free trade agreement or WTO government procurement agreement (GPA) partners.

UK performance in terms of regulatory transparency appears to be average compared to best performers. This reflects a combination of average performance in terms of time and costs to get a visa and a good ranking of the United Kingdom in the World Bank Doing Business Survey.

\section{Telecommunications}

The telecommunications sector is at the core of the information society and provides the network over which many other services are traded. Furthermore, without a modern telecommunications network, global value chains would not be possible. Open and competitive telecommunications markets are associated with higher broadband penetration rates and lower prices of telecommunications services, and in turn help firms in all sectors integrate into value chains and improve productivity.

The United Kingdom is the best performer together with Denmark and Lithuania in the telecommunications sector. There is a wide variation across countries and most emerging-market economies display more restrictive regulatory frameworks.

The strategic importance of the sector has prompted many countries to restrict foreigners from investing and operating in the sector. Restrictions to foreign investment are lower in the United Kingdom than in most best performer countries. Seven of the countries included in the STRI database have foreign equity limits in force and joint ventures are required in one country. Five countries require that at least half of the board members in telecommunications companies must be nationals, while 12 countries have an obligation that the majority of board members must be residents. Nine countries require that foreign investors bring net economic benefits to the host country as a condition for investing. Ten countries have limitations on cross-border mergers and acquisitions. By comparison, the United Kingdom applies lighter restrictions, notably screening without exclusion of economic interests in both the fixed and the mobile sector than what can be observed in most other countries.

In a network industry, access to essential facilities and switching costs may favour incumbent firms. These market imperfections may constitute a substantial entry barrier, even in the absence of explicit foreign entry restrictions. Barriers to competition is lower in the United Kingdom than in any other country, except Portugal, the best performer in the sector, and Germany. 
Figure 44. Services Trade Restrictiveness Index in telecommunications, 2020

A. Comparison across countries

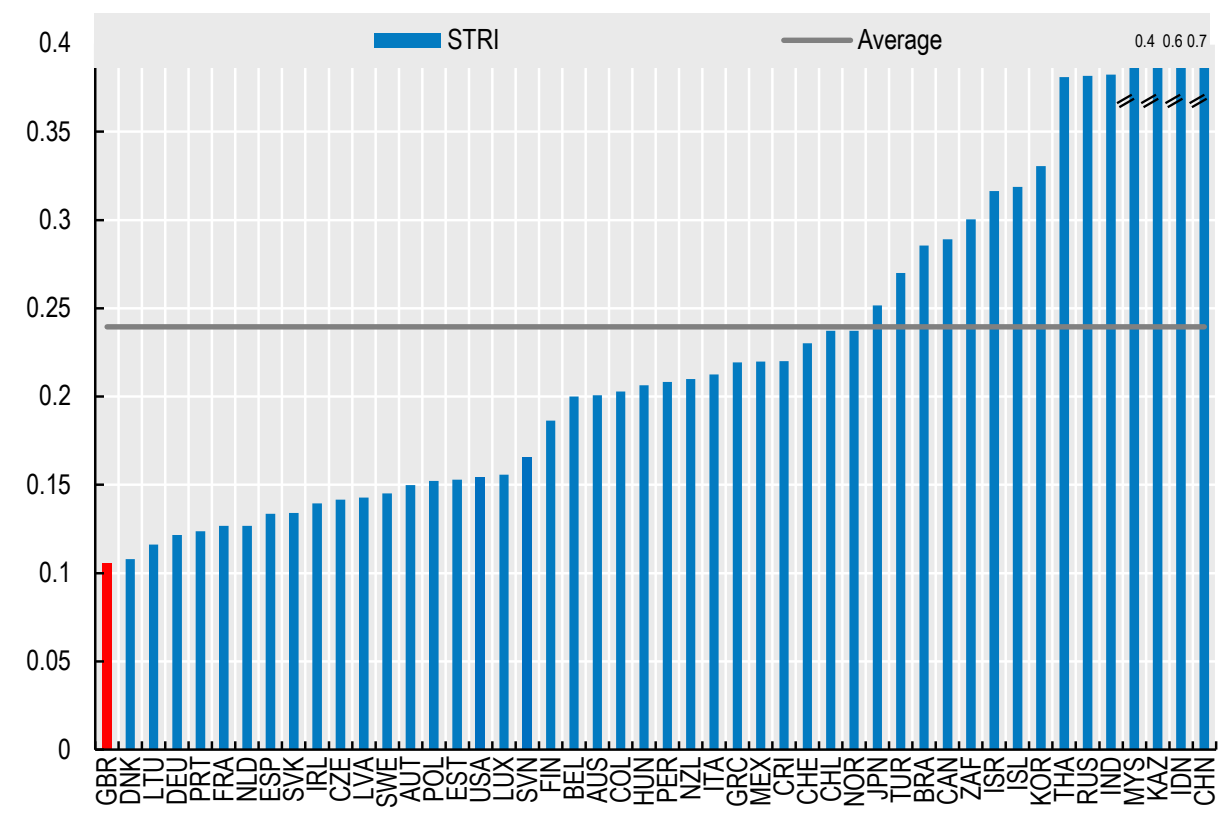

B. Breakdown and comparison with best performers

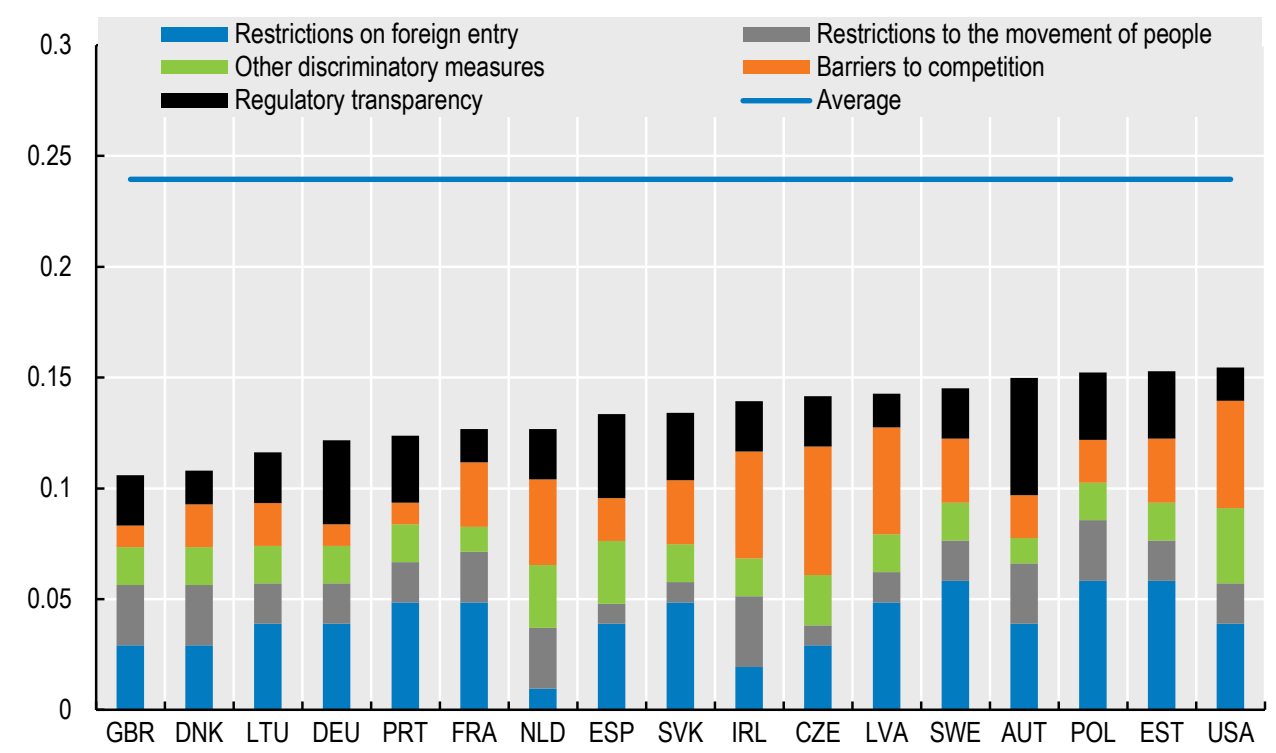

Note: The STRI indices take values between zero and one, one being the most restrictive. They are calculated on the basis of the STRI regulatory database which records measures on a Most Favoured Nations basis. Preferential trade agreements are not taken into account. The indices are based on laws and regulations in force on 31 October 2020. The sector covers wired and wireless telecommunications activities (ISIC rev 4 611 and 12).

Source: STRI regulatory database. 
The UK competition framework of the telecom sector is overall well designed, with an independent regulator that is separate from interested parties. In 17 countries included in the STRI database, the national regulatory authority is not independent from the government. In addition, the UK Government does not own major telecommunications firms, while government ownership is widely observed in the sector in other countries, contributing to barriers to competition in 22 of the countries covered by the STRI.

Restrictions to movement of people are average in the sector compared to best performers. Those are common restrictions and apply to people providing services on a temporary basis as intra-corporate transferees, contractual services suppliers or independent services suppliers. The United Kingdom also imposes quotas on one or more of these three categories. Only 11 other countries have introduced such quotas. Contrary to most countries, the duration of stay is not limited to less than three years in the United Kingdom, nor does it apply economic needs tests to stays that last longer than 3-6 months.

Other discriminatory measures are related to national treatment regarding taxes, subsidies, procompetitive regulation and public procurement. Like Portugal, the United Kingdom does not prohibit discrimination of foreign suppliers on procurement markets. In 41 countries public procurement regulation does not explicitly prohibit discrimination of foreign suppliers. In the United Kingdom, like in Portugal, foreign suppliers do not have non-discriminatory access to regulated rates and conditions for wholesale and retail international mobile roaming services (mobile).

The United Kingdom performs relatively well in terms of regulatory transparency, compared to the best performers, reflecting its good score in the World Bank Doing Business Survey and its average performance in terms of transparency and cost of visa deliverance.

\section{Motion pictures}

The motion picture sector is a global industry in which market transactions, whether within or across borders, are essentially the purchase of property rights, or the right to use somebody's property for a rental or fee. Sector-specific measures relate to the implementation of international treaties on the protection of copyrights and associated rights in a non-discriminatory manner. Films are also a cultural expression subject to a range of promotional and protective measures that are relevant for international trade.

The UK index in the motion pictures sector is below the average across countries, well below the maximum observed in China (Figure 45). The United Kingdom is relatively close to other large economies such as Germany or Spain, and more restrictive than Japan or the United States.

In the United Kingdom, the proportion of shares that can be acquired by foreign investors in publiclycontrolled firms is limited in the motion pictures sector. Restrictions in this area are common across OECD and emerging-market countries. Seven countries have limitations on foreign branches, six countries require that at least half the board of directors must be residents and nine countries require that foreign investors bring net economic benefits to the host country as a condition for investing. Six countries have limitations on cross-border mergers and acquisitions, while three countries control foreign capital flows in some shape or form.

Up until December 2020, labour-market tests existed for intra-corporate transferees, contractual services suppliers or independent services suppliers in the UK motion picture sector. All the countries covered have limitations on the movement on natural persons providing services on a temporary basis for these three categories. Ten countries impose quotas on one or more of these three categories, 36 countries apply economic needs tests to stays that last longer than 3-6 months and the duration of stay is limited to less than three years in 29 countries.

The comparison with best performers suggests that the United Kingdom imposes very little restriction related to competition. In the United Kingdom, national, state or provincial governments control at least one major firm in the sector. 
Figure 45. Services Trade Restrictiveness Index in motion pictures, 2020

\section{A. Comparison across countries}

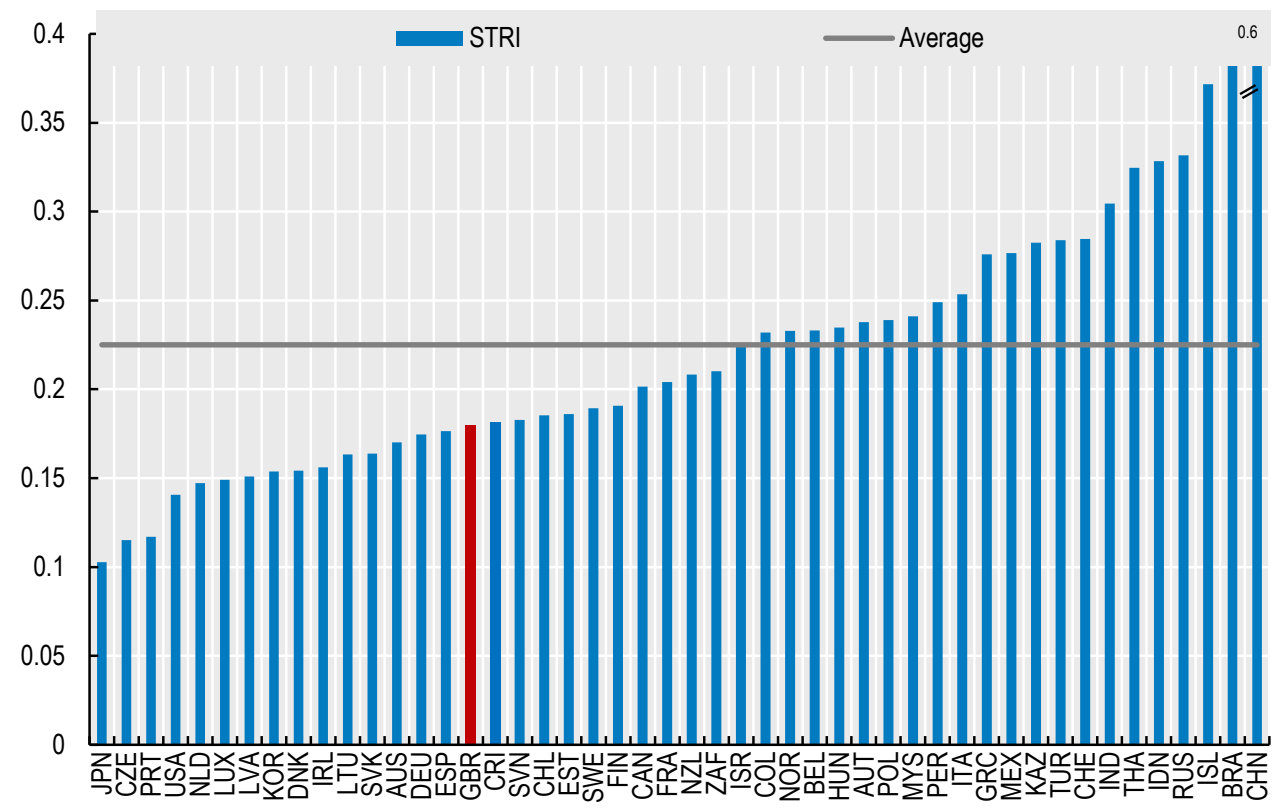

B. Breakdown and comparison with best performers

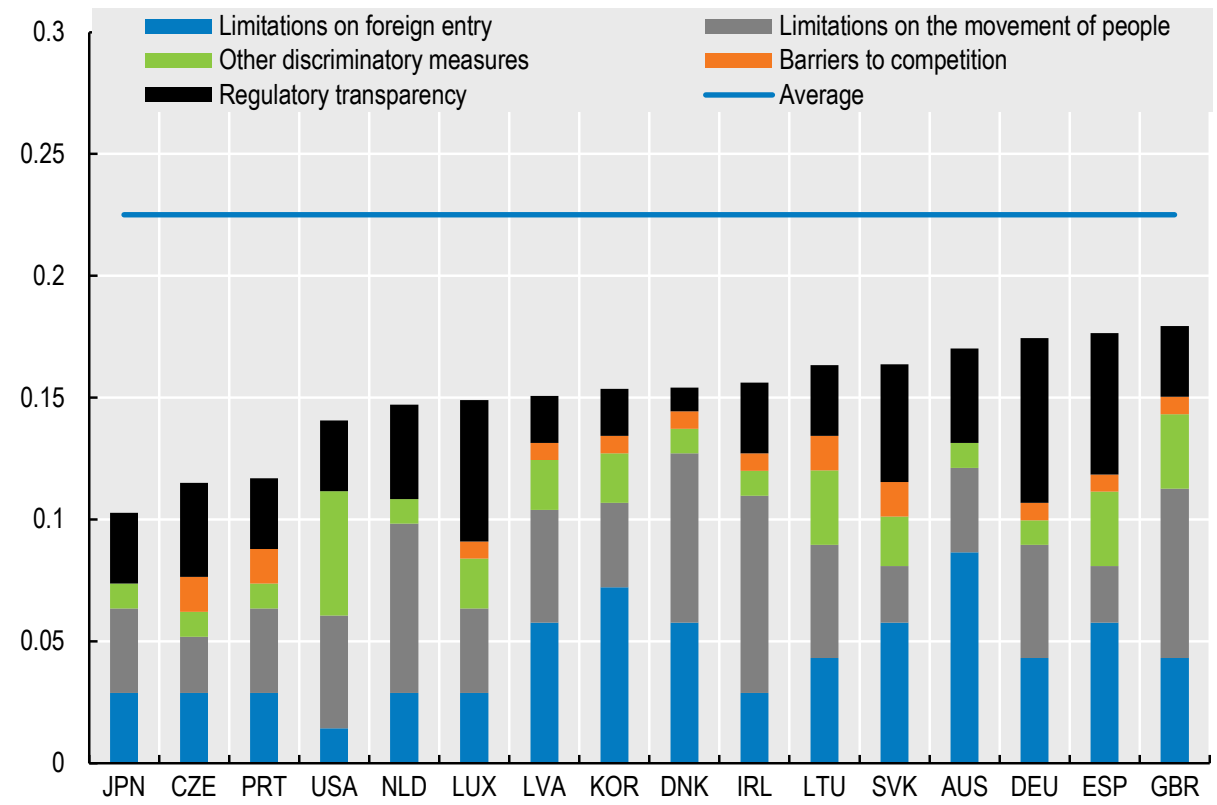

Note: The STRI indices take values between zero and one, one being the most restrictive. They are calculated on the basis of the STRI regulatory database which records measures on a Most Favoured Nations basis. Preferential trade agreements are not taken into account. The indices are based on laws and regulations in force on 31 October 2020. The sector of motion pictures is defined as motion picture, video and television programme production, post-production and distribution activities (ISIC rev 4 codes 5911-5914).

Source: STRI regulatory database. 
The United Kingdom appears to impose more restrictions registered in the "other discrimination categories" than most best-performers countries. Those restrictions include subsidies and tax relief for the production of films that are reserved to British productions passing the Cultural Test and quotas for independent and contractual suppliers. Those restrictions are less prevalent in the United Kingdom than in the United States and comparable to what can be observed in Spain. Restrictions in this area, are nevertheless common across the 48 countries covered by the STRI.

In the United Kingdom, the proportion of shares that can be acquired by foreign investors in publiclycontrolled firms is limited in the motion pictures sector. Restrictions in this area are common across OECD and emerging-market countries. Seven countries have limitations on foreign branches, six countries require that at least half the board of directors must be residents and nine countries require that foreign investors bring net economic benefits to the host country as a condition for investing. Six countries have limitations on cross-border mergers and acquisitions, while three countries control foreign capital flows in some shape or form.

Up until December 2020, labour-market tests existed for intra-corporate transferees, contractual services suppliers or independent services suppliers in the UK motion picture sector. All the countries covered have limitations on the movement on natural persons providing services on a temporary basis for these three categories. Ten countries impose quotas on one or more of these three categories, 36 countries apply economic needs tests to stays that last longer than 3-6 months and the duration of stay is limited to less than three years in 29 countries.

The comparison with best performers suggests that the United Kingdom imposes very little restriction related to competition. In the United Kingdom, national, state or provincial governments control at least one major firm in the sector.

The United Kingdom appears to impose more restrictions registered in the "other discrimination categories" than most best-performers countries. Those restrictions include subsidies and tax relief for the production of films that are reserved to British productions passing the Cultural Test and quotas for independent and contractual suppliers. Those restrictions are less prevalent in the United Kingdom than in the United States and comparable to what can be observed in Spain. Restrictions in this area, are nevertheless common across the 48 countries covered by the STRI.

The regulatory transparency policy area covers the implementation of copyright and related economic rights. As for the other sectors, the UK score in the regulatory transparency area is largely attributed to the fact that the country belongs to the top 40 performers in this domain and has an average performance in terms of transparency and cost of visa deliverance.

\section{Restrictions to trade in digitally-enabled services are low}

The rapid digitalisation of the economies and the change in working and consumption habits since the outbreak of the coronavirus have highlighted the need to limit trade barriers that affect services trade digitally (OECD, 2020a). There is evidence that lowering barriers to digital trade can be beneficial to trade and FDI (López González and Ferencz, 2018, Spinelli, Rouzet and Zhong, 2020; OECD, 2020b). This could be done unilaterally or through special chapters in bilateral or plurilateral agreements.

The stringency of such restrictions, as measured by the OECD digital STRI, appears to be low in the United Kingdom in 2020, compared to other countries (Figure 46). The other best performers in the sector are Costa Rica and Norway. The United Kingdom has not implemented reforms nor changed regulation covered by the digital STRI over the period 2014 to 2019. Denmark, Mexico and Portugal are examples of countries which softened their regulations during that period. In 2020, restrictions in this area have softened (OECD, 2021). 
Figure 46. Digital STRI

A. Comparison across countries, 2020

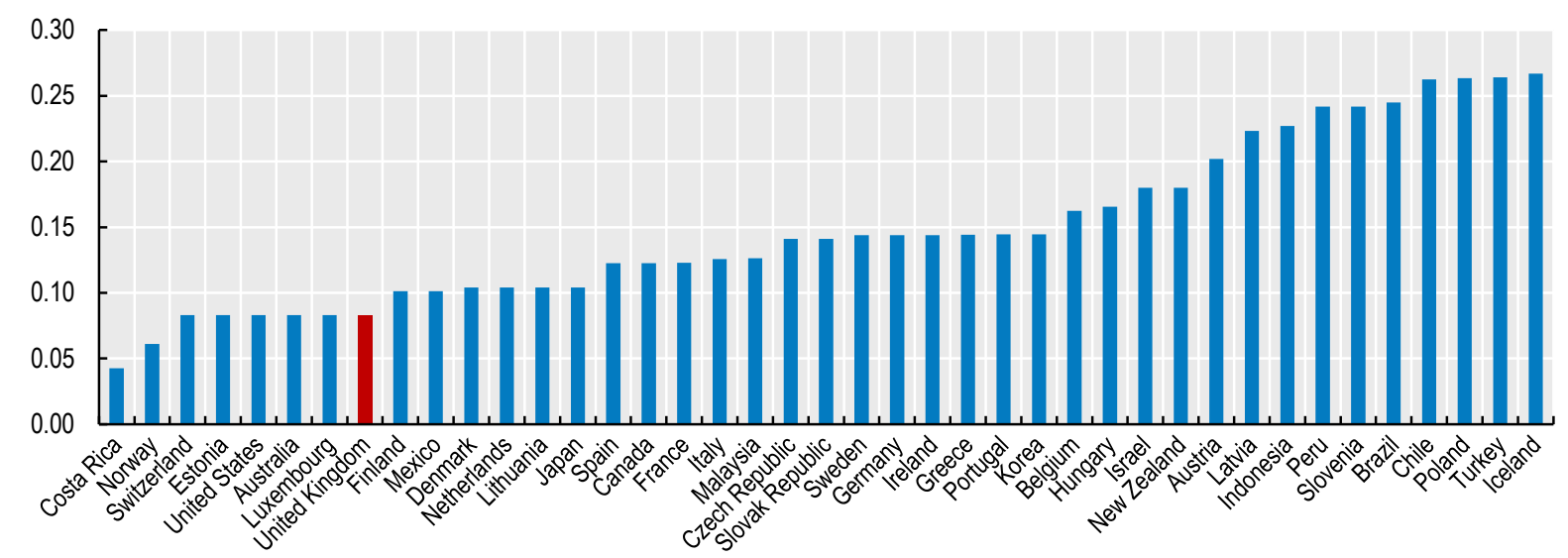

B. Breakdown and comparison with best performers, 2020

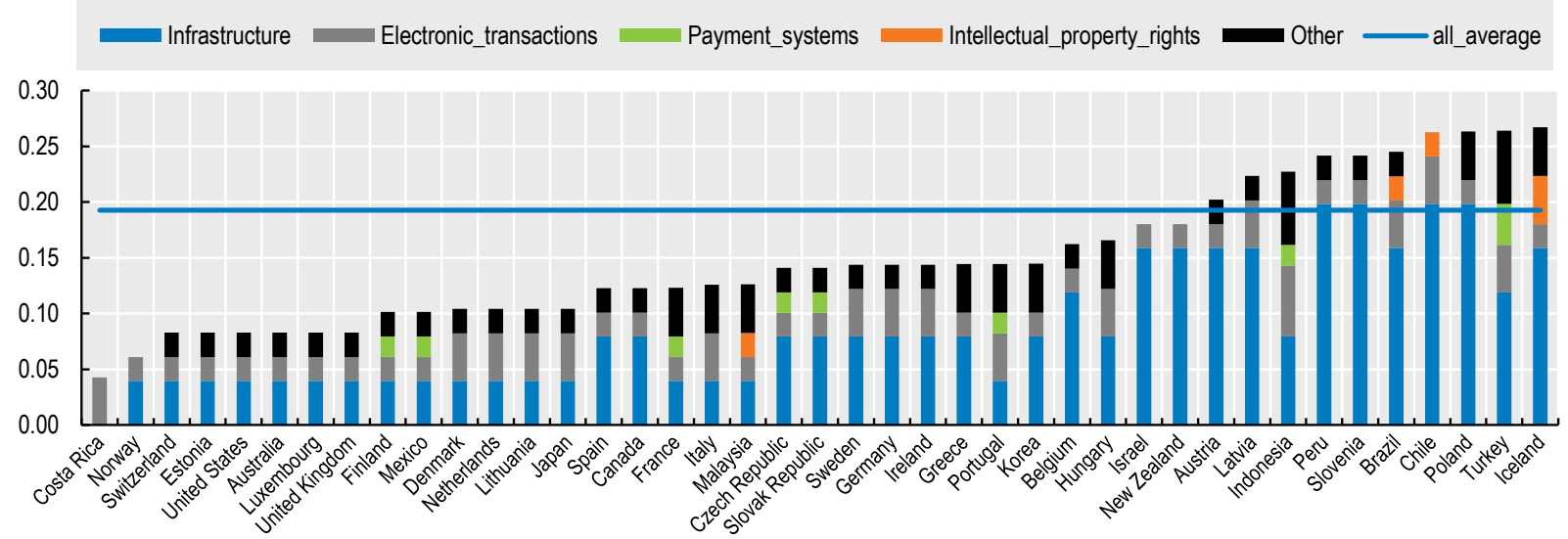

Note: The indicator varies between 0 (less restrictive) to 1 most restrictive. See Ferencz (2019) for more details on the methodology. Source: OECD STRI database.

Looking at specific measures, restrictions related to infrastructure and connectivity are in line with the bestperforming countries. The United Kingdom appears to be very liberal in terms of payment system and intellectual property rights. The United Kingdom is an intermediate situation regarding other digital restrictions to services trade. Local presence is required in order to provide cross-border services in the United Kingdom. Such a restriction does not exist in Norway. Regarding electronic transactions, the national contract rule for cross-border transaction deviates from internationally standardised rules. Norway and most countries follow a similar approach.

The United Kingdom has been a leader in initiating a reflection on how competition frameworks should be reformed to prepare for the rapid digitalisation of the economy and the change in behaviours this implies. In 2019, an independent expert panel on digital competition put forward a number of recommendations to ensure markets remain competitive as the economy becomes more digital (Digital Competition Expert Panel, 2019). One of the main recommendations was to enable greater personal data mobility and systems with open standards so that consumers can change service providers as they see fit (Box 5). The UK Competition Authorities (CMA) welcomed the conclusions of the Furman's report and responded to them by launching in June 2019 its digital markets strategy, setting out how it will continue to protect consumers 
in rapidly developing digital markets, while fostering innovation (CMA, 2019). It has now concluded a market study into online platforms, with recommendations in line with those of the expert panel report.

The potential barriers to entry in established digital platform markets mean that they cannot generally be considered freely contestable: the largest incumbents can exert significant market power over their users and may not be required to deliver the same level of positive outcomes as they would if facing normal competitive market conditions. OECD work suggests a broader set of considerations than current competition is needed to account for the specificities of digital markets (OECD, 2018). Benato et al. (2019) also suggest that ex post evaluation of the innovation impact of mergers is a feasible (conditional on data availability) and worthwhile task.

Although the UK competition framework is overall in line with best practises, it will be essential to continue to refine it to adapt it to the requirements of a well-functioning digital economy. Given the novelty of the process, it will be important that the new approach is widely understood and offers a high level of predictability.

\section{Box 5. Main recommendations of the Digital Competition Expert Panel}

On 13 March 2019, a panel of independent experts, led by Professor Jason Furman, formulated recommendations to the UK Government. The main strategic conclusions of the panel are reported here.

\section{Establishment of a "digital markets unit" (DMU)}

The panel calls for the establishment of a DMU, which would be an independent body and would be given the remit of using tools and frameworks that will support greater competition and consumer choice in digital markets.

\section{Changes to UK merger control law and policy}

These include updating the merger assessment framework to provide more opportunities to intervene, and to focus attention on technological developments and the possible loss of "potential competitors" as well as actual competitors; designating certain companies with "strategic market status" and requiring them notify the competition authority (CMA) of "all intended acquisitions"; and a "balance of harm" merger test allowing the CMA to be able to weigh-up (i) the magnitude and likelihood of harm from losing a rival and (ii) the magnitude and likelihood of potential benefits to consumers from efficiencies.

\section{Greater use of interim measures and revising applicable appeal standards}

The report suggests that the CMA should prioritise consumer enforcement work in digital markets, and should complement this with sufficient information gathering powers applicable to the digital economy.

In particular, it recommends that the antitrust enforcement regime should be updated to enable greater use of interim measures to prevent harm to competition during a pending antitrust investigation. In addition, appeal standards should be more closely aligned with the standards for judicial review and the ability to adduce new evidence in the course of an appeal should be removed.

\section{A global approach to digital enforcement}

The report concludes by calling for a more integrated global approach to the digital economy, including ensuring the effectiveness of remedies. 


\section{Identifying divergence in regulations between the United Kingdom and trade partners}

Differences in regulation - even without overall differences in restrictiveness - can affect trade costs, by making it necessary for firms to adopt different production technologies for different types of transactions (domestic versus cross-border with particular partners). The extent to which regulatory regimes in different countries diverge from one another can be assessed using the regulatory heterogeneity index developed by Nordås (2016), which measures divergences measure by measure in country pairs. This index is useful to monitor regulatory convergence, particularly in cases where trade agreements include regulatory cooperation. For each measure the country pair has a score of zero if both countries have the same answer (similar regulation) and one if they have different answers (diverging regulation). The scores are then aggregated using the STRI weights to compute regulatory heterogeneity indices for each country pair.

The regulatory heterogeneity indices measure a different source of cost of trading across borders than the STRI, namely the cost of having to comply with different regulatory requirements. Country pairs that have high STRIs but similar regulation as well as country pairs with low STRIs and similar regulation obtain a low score on the heterogeneity index.

Information for the STRI regulatory database suggests that the UK regulatory framework presents many similarities with the Netherlands and to a lesser extent Ireland in the six sectors covered by this progress report (Table 4). But there are differences across sectors.

Table 4. Regulatory convergence with the United Kingdom in 2020, by sector

\begin{tabular}{l|l|l}
\hline \multicolumn{1}{c|}{ Sector } & STRI Best Performer & \multicolumn{1}{c}{ Countries with little regulation divergence with the United Kingdom } \\
\hline Air transport & Chile & Lithuania, Denmark, Netherlands, Estonia, Latvia \\
\hline Road freight transport & Czech Republic & Netherlands, Portugal, France, Luxembourg, Estonia \\
\hline Accounting and auditing & Chile & Ireland, Czech Republic, Sweden, Netherlands, Finland, \\
\hline Architecture & Latvia & Ireland, Greece, Sweden, Norway, New Zealand \\
\hline Motion pictures & Japan & Netherlands, Ireland, United States, Luxembourg, Germany \\
\hline Telecommunications & United Kingdom & Portugal, Netherlands, Denmark, Germany, Austria \\
\hline
\end{tabular}

Source: STRI regulatory database.

Carrying out significant policy reforms only on the basis of sectoral best performers may be an impossible task as regulatory regimes may be too divergent. A more practical approach could be to prioritise reforms by identifying countries which are on par with the United Kingdom and among these selecting one or two whose regulatory framework is close to best practises. Such an approach would identify the following recommendations:

- Air transport: The United Kingdom would strongly benefit from explicitly prohibiting discrimination against foreign bidders to public procurement and allowing air carriers to exchange slots as is done in France.

- Road freight transport: Shortening procedures at customs for truck drivers as is done in the Netherlands would facilitate services provisions in this sector. Granting multiple entry visas to drivers from countries with which the United Kingdom has a bilateral road haulage agreement but currently need a visa to transit will help (Albania, Moldova, Serbia, Turkey and Belarus).

- Accounting, auditing and book-keeping services: Following the Netherlands' approach and removing equity restrictions related to the professional title for foreign auditors and setting up a full recognition of foreign qualifications would increase the overall openness of the UK auditing services.

- Architectural services: Allowing temporary licensing and easing the recognition of foreign qualifications with no exam and one year of local practice, as is done in the Netherlands, would increase openness. 


\section{There are very few differences within the UK internal market}

The United Kingdom is a unitary nation, but devolution implies that some regulatory divergences could be observed in the four countries (England, Scotland, Northern Ireland and Wales). The OECD STRI is based on regulations that applies generally within the United Kingdom and does not incorporate regional regulatory or legal divergences. Shepherd (2018) has constructed a comparable indicator for Northern Ireland and Shepherd (2019) for Scotland and Wales.

Shepherd (2019) concludes that policy restrictiveness is generally quite similar across the four UK constituent nations, except in the case of legal services. Small regional differences can be also observed in policy restrictiveness in air transport, distribution, legal services, and logistics storage and warehousing, but the size of the difference in restrictiveness is not substantial. In distribution, for example, Scotland does not impose maximum limits on shop opening times, whereas all other constituent nations do. In air transport, England does not have schedules for airport use, whereas the other constituent nations do.

Overall, despite the use of distinct legal instruments in individual constituent nations in some cases, the UK internal market typically displays very little regulatory heterogeneity, as there is no apparent difference in key regulatory structures in most sectors. Combining relatively little regulatory heterogeneity with a near absence of overt discrimination, leads to the conclusion that the UK internal market in services is quite integrated relative to benchmarks like the extent of completeness of the EU Single Market.

\section{References}

Benato A., S. Davies, F. Mariuzzo and P. Ormosi (2019), "Mergers and Innovation: Evidence from the Hard Disk Drive Market", Center for Competition Policy Working Paper, version 3.

López González, J. and J. Ferencz (2018), "Digital Trade and Market Openness", OECD Trade Policy Papers, No. 217, OECD Publishing, Paris.

OECD (2018), "Considering non Price Effects in Merger Control", Background Note by the Secretariat.

OECD (2020a), "Leveraging digital trade to fight the consequences of COVID-19", Policy brief, 7 July.

OECD (2020b), Digital Economy Outlook 2020, OECD publishing.

OECD (2021b), OECD STRI: Policy trend up to 2021, OECD Publishing.

OECD (2018), "Considering non Price Effects in Merger Control", Background Note by the Secretariat.

Spinelli F. D. Rouzet and H. Zhong (2020), "Networks of foreign affiliates: Evidence from Japanese micro-data" The World Economy, Vol. 43 Issue 7, July.

Shepherd, B., M. Decosterd, C. Castillo Comabella, and D. Stivas (2019), "EU Exit and Impacts on Northern Ireland's Services Trade: Evidence from Services Trade Restrictiveness Indices.", Report prepared for the Department for the Economy of Northern Ireland.

Shepherd, B. (2019), "Services Policies and Manufacturing Exports", In M. Helble and B. Shepherd (eds.) Leveraging Services for Development: Policies and Prospects, Tokyo: ADB and ADBI.

Shepherd B., M. Décosterd, C. Castillo Comabella, D. Stivas, R. Mehroz Khan, Yomeini Perez Andrade, and Y. Rovnov et al. (2019), "Non-Tariff Measures and the United Kingdom Internal Market".

Nordås, H. (2016), "Services Trade Restrictiveness Index (STRI): The Trade Effect of Regulatory Differences", OECD Trade Policy Papers, No. 189, OECD Publishing, Paris.

Nordås, H. and D. Rouzet (2015), "The Impact of Services Trade Restrictiveness on Trade Flows: First Estimates", OECD Trade Policy Papers, No. 178, OECD Publishing, Paris. 


\section{Scope for reforms and policy recommendations}

\section{Potential gains from unilateral liberalisation of services sectors}

Despite of an overall favourable environment for services trade in the United Kingdom, trade costs for services are still high. Several studies show that trade costs faced by services providers are significantly higher than barriers to trade in goods (Gervais and Jensen, 2019). Recent OECD research reports global average trade costs between $50 \%$ and $100 \%$ for most services sectors (Benz and Jaax, 2020). For 17 services sectors, the OECD estimates that average services trade costs in the United Kingdom are around $38 \%$ with a median of $28 \%$. These numbers show that even small regulatory reforms can contribute to substantial benefits for services exporters and importers. A reduction of services trade barriers can also benefit small and medium sized enterprises in particular (Benz et al., 2020).

Since December 2020, the United Kingdom has put in place a number of measures that have contributed to lower services trade costs (Figure 47). Labour-market tests for workers seeking to provide services on a temporary basis as intra-corporate transferees or independent suppliers were removed. This measure is expected to lower costs in all the sectors by an average of 3 to $4 \%$ after 3-5 years. In addition, foreign equity restrictions, which previously existed in air services, according to which non-EU nationals cannot own more than $49 \%$ in local airlines, were lifted. This is expected to have a marked impact on services costs in the industry. Combined with the removal of labour-market tests it would lower services trade costs by more than $25 \%$ in the sector.

Figure 47. Estimated reduction in services trade costs due to the liberalising reforms implemented in December 2020, percentage of export values, medium-term

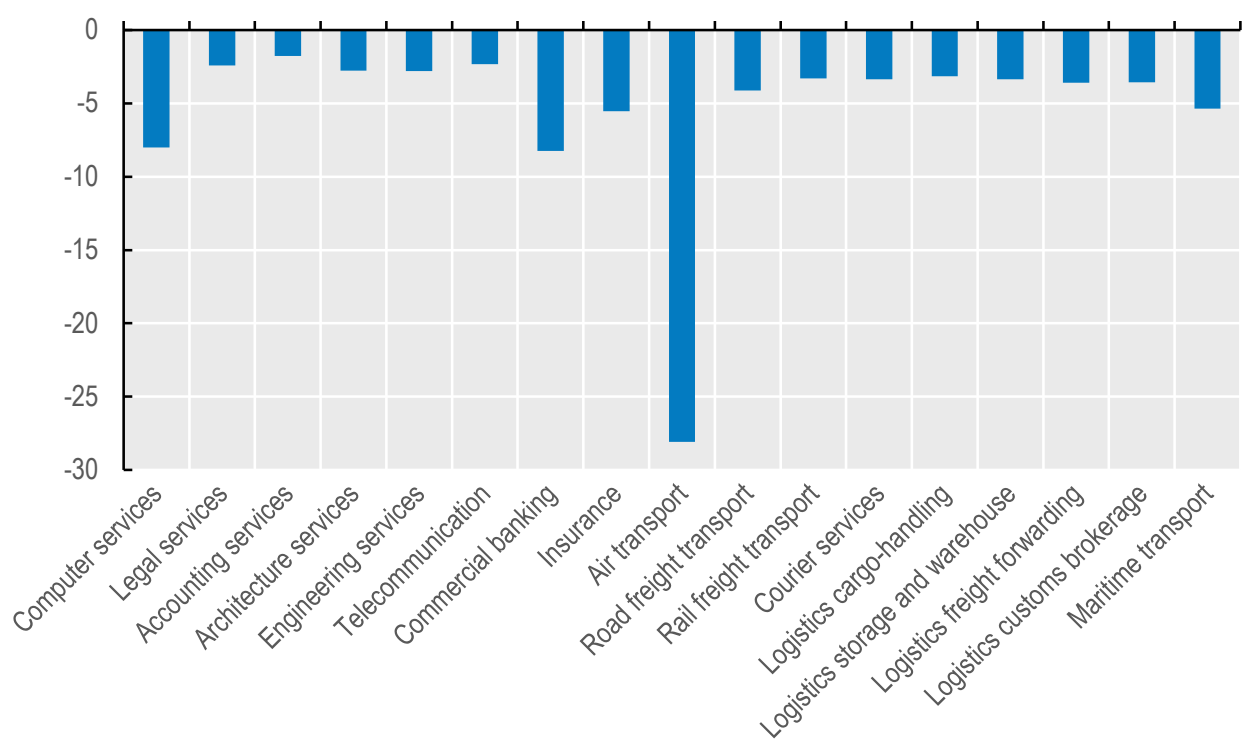

Note: Reforms include the removal of labour-market tests for intra-corporate transferees or independent suppliers and foreign restriction in air transport sector.

Source: OECD calculations using the STRI database and Benz and Jaax (2020). 
Despite these reforms, and although the stringency of regulations is usually relatively low in the United Kingdom compared to peers, there is still some scope to further liberalise some services sectors. This will bring down service-trade costs, increase competitiveness and foster services trade (Benz and Jaax, 2020; Nordas and Rouzet, 2015). To illustrate this point, this section seeks to identify the sectors where there is scope for reform and economic gains are the highest, by quantifying the impact for the United Kingdom of closing half of the STRI gap compared to the best-performer country in each individual services sector. Those changes are then translated into a decrease in services trade costs following Benz and Jaax (2020). Technical details are provided in Box 6 . The simulation is purely illustrative and relies on strong assumptions. The exercise does not account for the political sensitivity and appetite for a peculiar reform, in the United Kingdom or in international fora. It is assumed that the reform is implemented in the United Kingdom unilaterally and inter-sectoral spillovers are not accounted for.

\section{Box 6. Computing trade costs}

This box summarises the methodology developed in Benz and Jaax (2020) to compute trade costs. The empirical strategy employed to convert the information in the STRI database into Ad Valorem Equivalents (AVEs) is based on a gravity model. Traditionally used to analyse patterns of trade in goods, gravity models have also been widely applied to cross-border trade in services (Eaton and Kortum, 2018; Nordas and Rouzet, 2017; Van der Marel and Shepherd, 2013; Anderson et al., 2015).

Formally, the gravity model can be expressed as follows:

$$
\text { Exports }_{i j}=\frac{G D P_{i} G D P_{j}}{G D P_{\text {world }}}\left(\frac{\text { tradecost }_{i j}}{\Pi_{i} P_{j}}\right)^{(1-\sigma)}
$$

where the left-hand side variable represents the trade flow from exporter $i$ to importer $j$. The second term ensures that the model takes into account GDP proportionality, whereas the third term captures the role of trade costs which encompass two main components. First, pair-specific costs of economic transactions between two countries $i$ and $j$. Second, the above-mentioned country-specific costs of engaging in trade with the rest of the world, here represented by $\Pi_{i}$ and $P_{j}$. The parameter $\sigma$ is the elasticity of substitution between foreign and domestic goods and services.

This model remains valid when $i$ and $j$ reference the same country. In this case, the variable tradecost $_{i j}$ indicates internal trade costs within a country, while $\Pi_{i}$ and $P_{j}$ are defined as above and now indicate inward multilateral resistance and outward multilateral resistance of the same country. Calculated as the share of gross production that is not exported, the addition of a country's trade with itself aligns the gravity estimates with the modelling of choices between domestic and foreign goods (Yotov et al., 2016; Dai, Yotov and Zylkin, 2014; Yotov, 2012). Moreover, the inclusion of within-country trade permits to analyse the effect of multilateral policy variables, i.e. variables that do not vary bilaterally, without omitting multilateral resistance terms (Heid, Larch and Yotov, 2015).

The gravity estimates presented in this paper are run separately for each sector and estimated using the Poisson Pseudo Maximum Likelihood (PPML) technique introduced by Santos Silva and Tenreyro (2006). This approach is now commonly used for the estimation of the gravity model. It is superior to the traditional log-linearized estimation with ordinary least squares due to its robustness to different patterns of heteroscedasticity. Moreover, it allows retaining zeros in bilateral trade data, which would otherwise get lost in the logarithmic transformation of the model. 
The regressions rely on variations of the following specification:

$$
\text { exports }_{i j, k}=\exp \left(\beta_{1} \operatorname{STRI}_{j, k} \text { border }_{i j}+\beta_{2} \text { border }_{i j}+\gamma Z_{i j}+\eta_{i, k}+\mu_{j, k}+\varepsilon_{i j, k}\right)
$$

where the dependent variable are services exports from country $i$ to country $j$ in sector $k$ measured in million USD. Exporter and importer fixed effects $\eta_{i, k}$ and $\mu_{j, k}$ control for multilateral resistance terms and all other country-specific variables. A set of standard gravity variables (represented by $Z$ ) control for other determinants of bilateral trade costs. $\beta_{1}$ is the main coefficient of interest; it represents the effect of changes in the STRI score of the importer $j$ on the estimated flow of services exports from country $i$ to country $j$ relative to domestic services consumption in country $j$. Standard errors are clustered by exporter and importer.

Trade costs (expressed in percentage) are computed using the following equations:

$$
\text { trade_cost }=100 * \exp \left(\Delta S T R I * \frac{\beta_{1}}{1-\sigma}\right)
$$

Table 5. Coefficients used for the computation of trade costs

\begin{tabular}{l|c|c}
\hline \multicolumn{1}{c|}{ Sectors } & Trade elasticities & Import demand elasticities \\
& $\left(\beta_{1}\right)$ & -2.67 \\
\hline Communication & -4.515 & -2.21 \\
\hline Business & -3.920 & -1.54 \\
\hline Finance & -7.335 & -1.77 \\
\hline Insurance & -5.002 & -2.39 \\
\hline Transports and logistics & -3.543 & \\
\hline
\end{tabular}

Source: Benz and Jaax (2020).

Consistent with Section 3, illustrative simulations suggest that the United Kingdom exhibits some room to liberalise, particularly in accounting and architectural services and air transportation (Figure 48). Reforms combine changes horizontal changes that impact all sectors with sector-specific changes. For example, a liberalisation of cross-border data flows would achieve the hypothetical effect in ten out of 17 sectors considered for this analysis. Liberalisation of government procurement would achieve the hypothetical effect in eight of these sectors. Sectors where further sector-specific measures could help to achieve the hypothetical level of liberalisation include accounting, air transport and courier services. In auditing, efforts should be undertaken to improve the recognition of foreign qualifications. In air transport, a reduction of trade cost could be achieved by facilitating the lease of foreign aircrafts and allowing for the commercial exchange of slots. In courier services, there is no provision for the resolution of disputes between courier operators.

The resulting impact on trade costs is a combination of the initial level of regulation stringency (compared to the best performer), as well as the trade elasticity of regulations in the sectors. For example, in sectors where the United Kingdom is the best performer (i.e. experiences the lowest STRI score amongst the 48 countries covered), no scope for reform is identified in this calculation. This does not mean that the United Kingdom could not liberalise this sector further, but simply that it would go further than what has been observed in other countries. 
Figure 48. UK Trade costs reductions from halving the regulation gap compared to the best performer

A. Reduction in the STRI, percentage of initial level

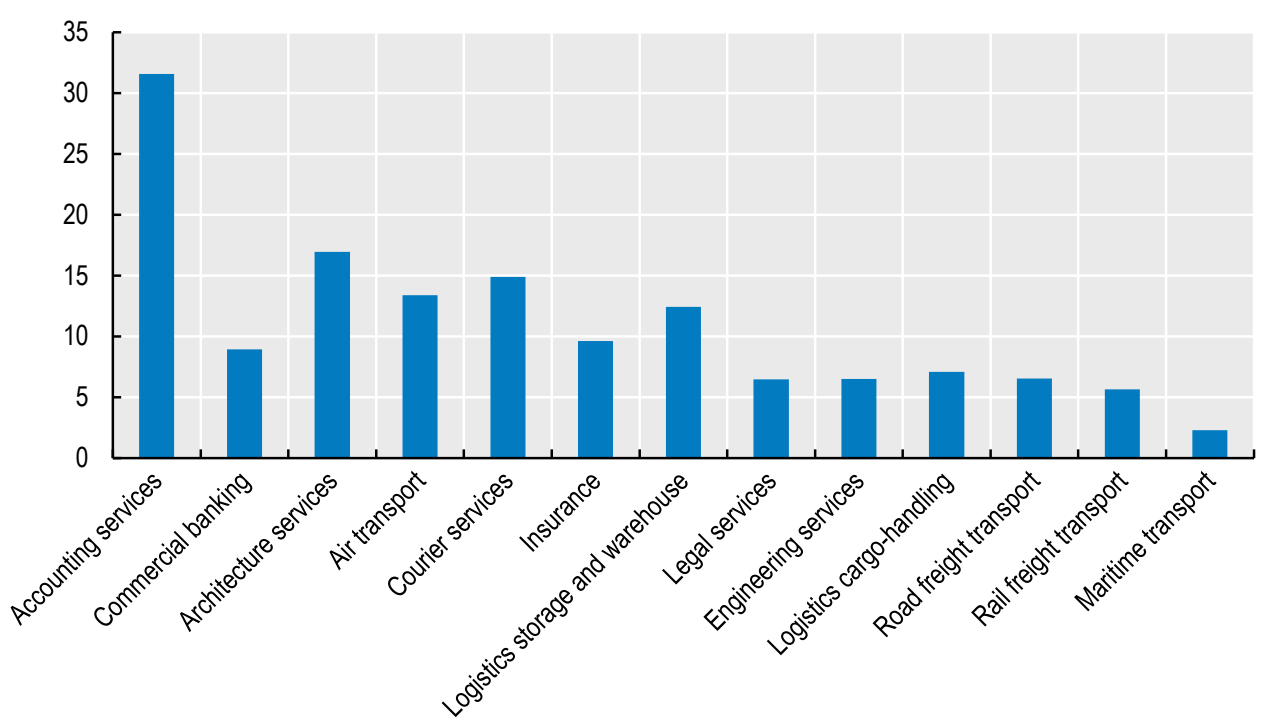

B. Trade cost, difference to baseline, percentage of trade values

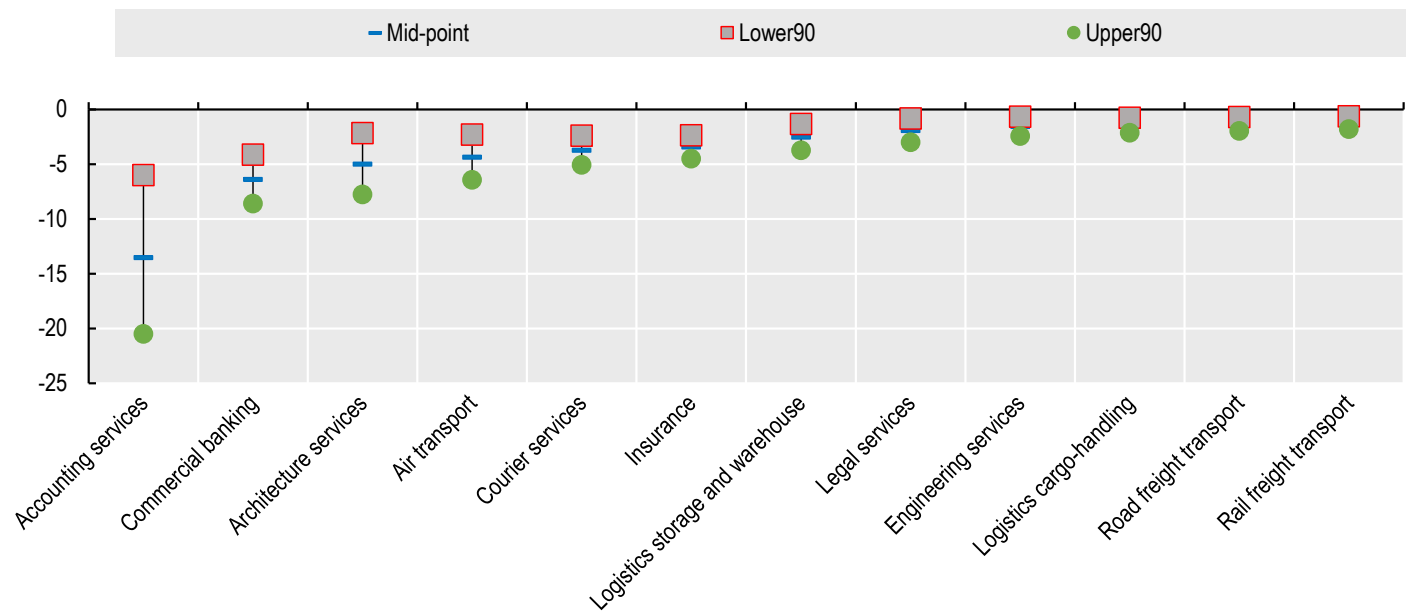

Note: Ninety percent confidence intervals are computed using the standard errors of the trade elasticity estimated from a gravity model. Source: OECD calculations using the STRI database and Benz and Jaax (2020).

The impact of reforms is expected to vary widely across sectors:

- Simulations suggest that accounting services would benefit the most from a reform, with expected decrease in trade costs comprised between $6 \%$ to $21 \%$ for accounting services. This reflects essentially the existing stringency of regulation in this sector (Section 3 ).

- Gains would be lower, though still significant in architecture services, ranging between $2 \%$ to $7 \%$.

- Gains would amount to $2 \%$ to $5 \%$ in courier services.

- Potential reductions in services trade costs appear to be lower in other sectors where the United Kingdom is already amongst the best performer countries. 
- Some gains could also be expected in commercial banking and insurance. However, rather than pointing to existing stringent regulations, those results underline the high sensitivity of trade costs to regulation in these sectors. To a large extent, performances in this sector will depend on the decision in terms of equivalence, which is not accounted for in the simulation.

Closing half of the gap to best performers implies an average reduction of the STRI of around $9 \%$ and could lead to an average decrease in services trade costs of about $3.5 \%$ in the medium term. Those reforms are also likely to boost manufacturing trade, thereby strengthening the recovery. To give an order of magnitude, Shepherd (2019) suggests that the UK's total manufacturing exports would be nearly $3 \%$ higher if policy measures included in the STRI were liberalised so as to reduce the UK score by $10 \%$.

Gains from reforms could also be obtained through bilateral agreements, especially between partners with already high levels of bilateral trade flows. The scope and extent of the agreements will determine the extent of gains and vary across agreements. While unnecessary trade costs harm consumers and businesses and reduce domestic welfare, a liberalisation of all policy measures included in the STRI may not necessarily be optimal for all countries at any point in time. Some of these measures are used to achieve other policy objectives, which might have a higher domestic priority. However, estimates of corresponding trade costs can inform policy makers on relevant trade-offs when using trade-restrictive measures for the pursuit of domestic policy priorities

\section{Recommendations to strengthen the recovery and ensure its sustainability}

The analysis undertaken in this report has shown that the United Kingdom has the potential to benefit from further liberalisation in services trade regulations. Beyond the implied reduction in trade costs, this could also benefit incremental innovation (Aghion, Bergeraud and Van Reenen, 2021). Given the importance of services trade to support the recovery, it will be key to tap into this potential to maximise the speed and the strength of the recovery, and in the long-term foster living standards.

The evidence presented helps to formulate recommendations to ensure an open and competitive services sector.

Given the severity of the COVID-19 crisis, the immediate focus of policy should be on short-term measures that can boost the strength and the pace of the recovery. In particular, priority should be given to:

- Wind down the trade restrictions which were imposed to contain the pandemic or trade barriers that pre-exist the crisis. In particular, trade restrictions on digital trade are likely to have even more effect as social distancing rules are put in place.

- End travel restrictions that are found to raise trade service costs and dampen services trade, as soon as the pandemic is contained.

- Trade facilitation measures can help foster services trade and are particularly important in the current context. As described in OECD (2020), they can ensure that all formalities are transparent and accessible to all traders, especially small and micro firms; they can expedite standard formalities to leave room for necessary additional COVID-19 related controls; and they can digitise all possible processes as much as their infrastructure allows to speed up processing and reduce the need for physical contact between border agencies and traders.

- Address barriers to services jointly with those of goods, given the complementary nature of services and goods trade.

- Protect vulnerable workers and facilitate the transition to digital through training.

- Continue support to small or young firms to help them overcome temporary financing difficulties resulting from the economic fallout, while facilitating the exit of insolvent firms. 
Once the recovery is underway, it will be important to address longstanding structural issues, with the objective to foster services trade and productivity growth. At the national level, regulations in services sectors are generally less stringent in the United Kingdom than in most OECD countries, and in its key trade partners. There are a few exceptions, however:

- There is room to liberalise regulations related to labour-market access of foreign services providers in the accounting and the architecture services.

- Refining the competition framework and adapt it to new business models will facilitate the move to a digital economy.

\section{References}

Aghion P., A. Bergeraud and J. Van Reenen (2021), The Impact of Regulation on Innovation, NBER Working Paper n. 28381, January.

Anderson, J. et al. (2015), Dark Costs, Missing Data: Shedding Some Light on Services Trade, The World Bank.

Benz S. and A. Jaax (2020), "The Cost of Regulatory Barriers to Trade in services: New Estimates of ad valorem Tariff", OECD Trade Policy Paper, OECD Publications, Paris.

Benz S., D. Rouzet and F. Spinelli (2020), „Firm heterogeneity in services trade: Micro-level evidence from eight OECD countries", The World Economy, Vol. 43/11, pp. 2905-2931.

Dai, M., Y. Yotov and T. Zylkin (2014), "On the Trade-Diversion Effects of Free Trade Agreements", Economics Letters, Vol. 122/2, pp. 321-325.

Eaton, J. and S. Kortum (2018), "Trade in Goods and Trade in Services," in Lili Yang Ing and Miaojie Yu (eds), World Trade Evolution: Growth, Productivity, and Employment, Routledge.

Gervais, A. and J. Jensen (2019), "The tradability of services: Geographic concentration and trade costs", Journal of International Economics, Vol. 118, pp. 331-350

Heid, B., M. Larch and Y. Yotov (2015), A Simple Method to Estimat the Effects of Non-Discriminatory Trade Policy Within Structural Gravity Models.

Nordås, H. and D. Rouzet (2017), "The Impact of Services Trade Restrictiveness on Trade Flows", World Economy, Vol. 40/6.

OECD (2020), Trade facilitation and the COVID-19 pandemic, OECD Policy Responses to Coronavirus (Covid-19).

Santos Silva, J. and S. Tenreyro (2006), "The Log of Gravity", Review of Economics and Statistics, Vol. 88/4, pp. 641-658.

Van der Marel, E. and B. Shepherd (2013), "Services Trade, Regulation and Regional Integration: Evidence from sectoral data", World Economy, Vol. 36/11, pp. 1393-1405.

Yotov, Y. (2012), "A Simple Solution to the Distance Puzzle in International Trade", Economics Letters, Vol. 117/3, pp. 794-798.

Yotov, Y. et al. (2016), An Advanced Guide to Trade Policy Analysis: The Structural Gravity Model, World Trade Organization. 


\section{OECD TRADE POLICY PAPERS}

This report was prepared for publication by the OECD Secretariat.

This report, as well as any data and any map included herein, are without prejudice to the status of or sovereignty over any territory, to the delimitation of international frontiers and boundaries and to the name of any territory, city or area.

The statistical data for Israel are supplied by and under the responsibility of the relevant Israeli authorities. The use of such data by the OECD is without prejudice to the status of the Golan Heights, East Jerusalem and Israeli settlements in the West Bank under the terms of international law.

Comments are welcome and can be sent to tad.contact@oecd.org.

(C) OECD (2021)

The use of this work, whether digital or print, is governed by the Terms and Conditions to be found at http://www.oecd.org/termsandconditions. 